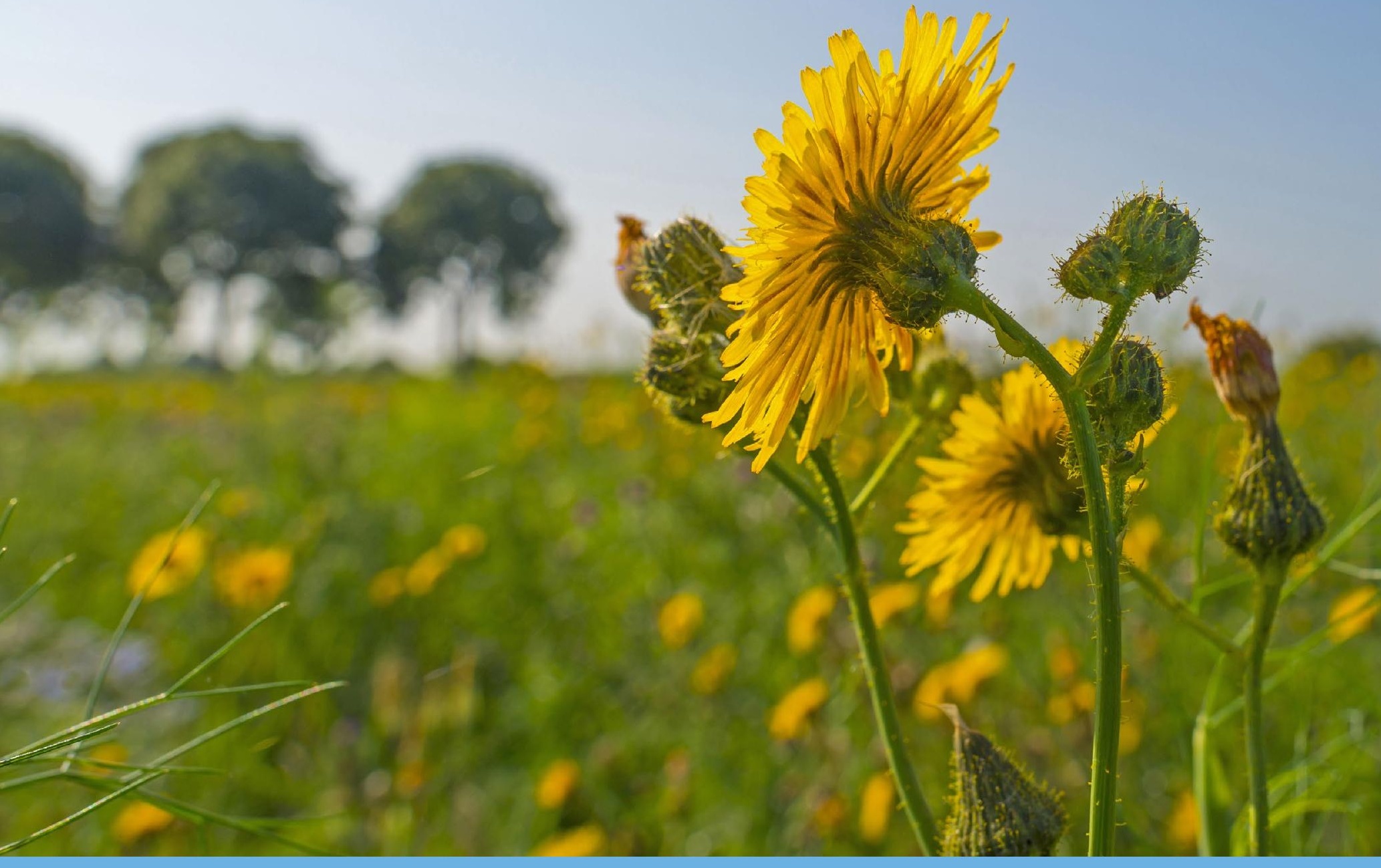

\title{
Bijdrage van Green Deals aan de beleidsdoelen voor natuur en biodiversiteit
}



Bijdrage van Green Deals aan de beleidsdoelen voor natuur en biodiversiteit 
Dit Technical report is gemaakt conform het Kwaliteitshandboek van de unit Wettelijke Onderzoekstaken Natuur \& Milieu.

De WOT Natuur \& Milieu voert wettelijke onderzoekstaken uit op het beleidsterrein natuur en milieu. Deze taken worden uitgevoerd om een wettelijke verantwoordelijkheid van de minister van Economische Zaken te ondersteunen. De WOT Natuur \& Milieu werkt aan producten van het Planbureau voor de Leefomgeving, zoals de Balans van de Leefomgeving en de Natuurverkenning. Verder brengen we voor het ministerie van Economische Zaken adviezen uit over (toelating van) meststoffen en bestrijdingsmiddelen, en zorgen we voor informatie voor Europese rapportageverplichtingen over biodiversiteit.

\section{Disclaimer WOt-publicaties}

De reeks 'WOt-technical reports bevat onderzoeksresultaten van projecten die kennisorganisaties voor de unit Wettelijke Onderzoekstaken Natuur \& Milieu hebben uitgevoerd.

Dit onderzoek is uitgevoerd in samenwerking met het Planbureau voor de Leefomgeving (PBL). Het $P B L$ is een inhoudelijk onafhankelijk onderzoeksinstituut op het gebied van milieu, natuur en ruimte, zoals gewaarborgd in de Aanwijzingen voor de Planbureaus, Staatscourant 3200, 21 februari 2012.

Dit onderzoeksrapport draagt bij aan de kennis die verwerkt wordt in meer beleidsgerichte publicaties zoals Natuurverkenning, Balans van de Leefomgeving en andere thematische verkenningen.

Het onderzoek is gefinancierd door het Ministerie van Economische Zaken (EZ). 


\section{Bijdrage van Green Deals aan de beleidsdoelen voor natuur en biodiversiteit}

R.J.H.G. Henkens, M.M.P. van Oorschot en J. Ganzevles

Wettelijke Onderzoekstaken Natuur \& Milieu

Wageningen, juli 2017

WOt-technical report 94

ISSN 2352-2739

DOI: $10.18174 / 418269$ 


\section{Referaat}

Henkens, R.J.H.G., M.M.P. van Oorschot en J. Ganzevles (2017). Bijdrage van Green Deals aan de beleidsdoelen voor natuur en biodiversiteit. Wettelijke Onderzoekstaken Natuur \& Milieu, WOt-technical report 94. 66 blz.; 7 fig.; 2 tab.; 40 ref; 2 Bijlagen.

Het afsluiten van Green Deals (GDs), waarbij maatschappelijke partners worden uitgenodigd om met oplossingen voor groene groei te komen, is een optie waarmee de Nederlandse overheid innovatie stimuleert. In dit onderzoek is nagegaan wat de bijdrage is van de 41 GDs Biodiversiteit (eind 2016) aan de beleidsdoelen, zoals verwoord in de Rijksnatuurvisie 2014 en de Uitvoeringsagenda Natuurlijk Kapitaal. De ambities van de GDs blijken goed aan te sluiten op de verschillende beleidsdoelen. Ecologische effecten worden nauwelijks gemonitord. Desalniettemin lijkt het effect van veel GDs beloftevol, doordat vaak goede stappen worden gezet in het innovatieproces, met de juiste partijen, met concrete op natuur en biodiversiteit gerichte doelstellingen en met een grote potentie voor opschaling. Door een gerichtere sturing op de formulering van GD-doelen en de samenstelling van betrokken partijen, kan de effectiviteit van Green Deals nog verder worden vergroot.

Trefwoorden: Green Deals, biodiversiteit, Rijksnatuurvisie, Uitvoeringsagenda Natuurlijk Kapitaal, innovatie, groene groei

\section{Abstract}

Henkens, R.J.H.G., M.M.P. van Oorschot \& J. Ganzevles (2017). The contribution made by Green Deals to nature and biodiversity policy objectives. Statutory Research Tasks Unit for Nature \& the Environment (WOT Natuur \& Milieu, WUR). Wot-technical report 94. 66 p.; 7 Figs; 2 Tabs; 40 Refs; 2 Appendices.

Green Deals (GDs) are agreements made between the Dutch government and social partners in which the partners are invited to come up with innovative solutions for green growth. This study investigated the contribution being made by the 41 GDs on Biodiversity (at the end of 2016) to the policy objectives in the Government vision on nature and the Natural Capital Agenda. The ambitions of the GDs appeared to correspond well with the various policy objectives. Although the ecological effects are hardly being monitored at all, the potential impacts of the GDs appear to be promising because many projects have made significant progress with innovation, with the right partners, and towards concrete objectives for nature and biodiversity, with great potential for scaling up. The Green Deals can be made even more effective by tying GD objectives more closely to policy objectives and ensuring an optimal mix of partners.

Keywords: Green Deals, biodiversity, Government vision on nature, Natural Capital Agenda, innovation, green growth

Auteurs: René Henkens (WEnR), Mark van Oorschot (PBL), Jurgen Ganzevles (PBL)

\section{(c) 2017 Wageningen Environmental Research (WEnR)}

Postbus 47, 6700 AA Wageningen

Tel: (0317) 480700 ; e-mail: info.alterra@wur.nl

Planbureau voor de Leefomgeving (PBL)

Postbus 30314, $2500 \mathrm{GH}$ Den Haag

Tel: (070) 328 8700; e-mail: info@pbl.nl

De reeks WOt-technical reports is een uitgave van de unit Wettelijke Onderzoekstaken Natuur \& Milieu, onderdeel van Wageningen UR. Dit report is verkrijgbaar bij het secretariaat. De publicatie is ook te downloaden via www.wur.nl/wotnatuurenmilieu.

Wettelijke Onderzoekstaken Natuur \& Milieu, Postbus 47, 6700 AA Wageningen Tel: (0317) 4854 71; e-mail: info.wnm@wur.nl; Internet: www.wur.nl/wotnatuurenmilieu.

Alle rechten voorbehouden. Niets uit deze uitgave mag worden verveelvoudigd en/of openbaar gemaakt door middel van druk, fotokopie, microfilm of op welke andere wijze ook zonder voorafgaande schriftelijke toestemming van de uitgever. De uitgever aanvaardt geen aansprakelijkheid voor eventuele schade voortvloeiend uit het gebruik van de resultaten van dit onderzoek of de toepassing van de adviezen. 


\section{Woord vooraf}

Het Rijk zet sinds 2011 het instrument Green Deals in. Daarbij gaat het om vrijwillige afspraken tussen maatschappelijke partijen om groene innovatie en verduurzaming te bevorderen. De lijst met deals is ondertussen gegroeid tot meer dan 200. De thema's waarop deals worden afgesloten zijn water, klimaat, grondstoffen, biobased economy, biodiversiteit, mobiliteit, energie, voedsel en bouw (www.greendeals. $\mathrm{nl}$ ). Het gaat telkens om concrete projecten waarin maatschappelijke partijen afspraken maken om met innovatieve ideeën de verduurzaming van de economie verder te helpen. Aan elke Green Deal doet ten minste één ministerie mee. De partijen gaan inspanningsverplichtingen aan. Green Deals hebben daarom de vorm van een convenant, het zijn géén wettelijk bindende afspraken.

Maatschappelijke partijen blijken duidelijk warm te lopen voor samenwerking. Wel lopen de onderwerpen wijd uiteen, van het stimuleren van insectenfarms in Nederland, tot het verduurzamen van de zorg. Gezien het grote aantal deals kun je deze aanpak een succes noemen, maar het roept ook de vraag op wat ze nu concreet opleveren aan vernieuwing voor de beoogde maatschappelijke doelen. Voor deze studie hebben we dat in het bijzonder onderzocht voor natuur en biodiversiteit, waarbij de verschillende doelen van de overheid zoals die zijn verwoord in de Rijksnatuurvisie en de Uitvoeringsagenda Natuurlijk Kapitaal als uitgangspunt dienen. Daarmee hopen we een beeld te geven van de mogelijkheden die dit instrument biedt. En ook hoe het kan bijdragen aan meer maatschappelijke betrokkenheid bij natuur en biodiversiteit en integratie in verschillende sectoren.

René Henkens

Mark van Oorschot

Jurgen Ganzevles 



\section{Inhoud}

Woord vooraf

$\begin{array}{llr}1.1 & \text { Achtergrond } & 17\end{array}$

$\begin{array}{llr}1.2 & \text { Onderzoeksvraag } & 17\end{array}$

$\begin{array}{llr}1.3 & \text { Werkwijze en leeswijzer } & 18\end{array}$

$2 \quad$ Aansluiting van GD-doelen op doelen natuur- en biodiversiteitbeleid

\begin{tabular}{ll}
2.1 & Inleiding \\
\hline
\end{tabular}

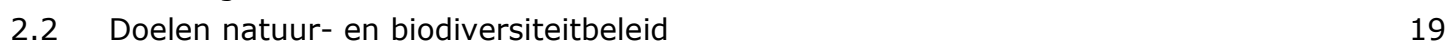

$\begin{array}{lll}2.3 & \text { GDs Biodiversiteit en de Rijksnatuurvisie } 2014 & 20\end{array}$

2.3.1 Overeenkomst tussen doelen Rijksnatuurvisie en GDs $\quad 20$

2.3.2 Aansluiting van afzonderlijke GD-doelen op doelen Rijksnatuurvisie $\quad 23$

2.4 GDs Biodiversiteit en de Uitvoeringsagenda Natuurlijk Kapitaal 25

$\begin{array}{lll}2.5 & \text { Samenvatting } & 28\end{array}$

3 Het potentiële effect van de Green Deals op natuur en biodiversiteit 29

3.1 Inleiding 29

3.2 Indicatoren om het potentiële effect op natuur en biodiversiteit te kunnen analyseren 29

3.2.1 Betrokkenheid kennisinstellingen natuur en biodiversiteit en andere GD-partijen 29

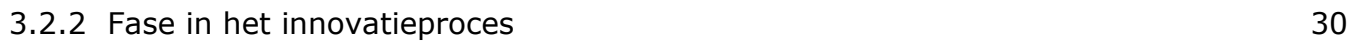

3.2.3 Natuur en biodiversiteit als hoofddoel 33

3.2.4 SMART-formulering van doelen $\quad 33$

$\begin{array}{ll}3.2 .5 & \text { Potentie voor opschaling }\end{array}$

$\begin{array}{lll}3.3 & \text { Potentieel effect van de GDs op natuur en biodiversiteit } & 34\end{array}$

3.3.1 Natuur en biodiversiteit in het Natuurnetwerk Nederland 35

3.3.2 Natuur en biodiversiteit in het agrarisch gebied 36

$\begin{array}{ll}\text { 3.3.3 Natuur en biodiversiteit in het stedelijk gebied } & 37\end{array}$

3.3.4 Ecologische verbindingen tussen natuurlijke, agrarische en stedelijke gebieden 39

3.3.5 Natuur en biodiversiteit internationaal $\quad 39$

$\begin{array}{lll}3.4 & \text { Samenvatting } & 41\end{array}$

4 Green deals Biodiversiteit nader beschouwd 443

4.1 De meerwaarde van de GDs Biodiversiteit $\quad 43$

$\begin{array}{lll}\text { 4.1.1 Meerwaarde van de GD-aanpak } & 43\end{array}$

4.1.2 GD geeft invulling aan maatschappelijk verantwoord ondernemen 43

4.2 Aandachtspunten bij opzetten en monitoren GDs Biodiversiteit 44

$\begin{array}{ll}\text { 4.2.1 Samenstelling GD-partijen } & 44\end{array}$

4.2.2 Formulering GD-doelen $\quad 44$

4.2.3 Monitoring effecten natuur en biodiversiteit $\quad 45$

4.3 Kansen voor nieuwe GDs Biodiversiteit $\quad 45$

$\begin{array}{lll}\text { 4.3.1 Opschaling kansrijke GDs } & 45\end{array}$

4.3.2 Meer sturing op biodiversiteitthema's en GD-partijen $\quad 45$

4.3.3 Positie Green Deals in instrumentenmix 47

$\begin{array}{lll}4.4 & \text { Samenvatting } & 47\end{array}$ 
Verantwoording

Bijlage 1 Scoringstabellen GDs Biodiversiteit

53

Bijlage 2 Interviewverslagen

55

Vlinderstichting

55

Stichting Veldleeuwerik

58

Vereniging Van Nederlandse Houtondernemingen (VVNH)

60

Stichting Innovatie Recreatie en Ruimte (STIRR) 


\section{Samenvatting}

Het afsluiten van Green Deals (GDs), waarbij maatschappelijke partners (bijvoorbeeld bedrijven, NGOs, kennisinstellingen) worden uitgenodigd om met oplossingen voor groene groei te komen, is een optie waarmee de Nederlandse overheid innovatie stimuleert. Zowel om problemen op te lossen, knelpunten te identificeren en aan te pakken, als om 'verdienen met groen' vorm te geven en op te schalen.

De diverse vormen van GDs worden gerangschikt onder negen thema's, waaronder het thema biodiversiteit $^{1}$. De vraag voor dit onderzoek was om na te gaan wat de potentiële bijdrage is van de 41 GDs Biodiversiteit (situatie eind 2016) aan de beleidsdoelen zoals verwoord in de Rijksnatuurvisie 2014 en de Uitvoeringsagenda Natuurlijk Kapitaal. Dat is gedaan door de GDs te analyseren op hun relevantie voor de verschillende overheidsdoelen en op hun potentie die tot daadwerkelijke effecten leiden voor natuur en biodiversiteit. Hierbij is een brede blik op natuur en biodiversiteit gehanteerd, met zowel aandacht voor kwantiteit als kwaliteit. Daarbij ligt de nadruk op effecten voor natuur en biodiversiteit en minder op de effecten voor de samenleving of de economie, zoals bepaalde ecosysteemdiensten die de natuur aan de mens levert (bijvoorbeeld energie uit biomassa). Doordat de effecten op natuur nauwelijks worden gemonitord en zich vaak pas na jaren etaleren, gaat het om een analyse van potentiële effecten. Betrokkenen bij een aantal kansrijke GDs zijn voorts geïnterviewd om een beeld te krijgen van de werking van het instrument GDs in de praktijk. Uit de analyses kunnen de volgende conclusies worden getrokken.

\section{Green Deals Biodiversiteit leveren bijdragen aan meer beleidsdoelen van de overheid} Alle GDs Biodiversiteit sluiten aan op één of meer doelen van de Rijksnatuurvisie 2014. Voor twee derde van de GDs is behoud of ontwikkeling van natuur en biodiversiteit (direct of indirect) een hoofddoel. Ongeveer de helft van de GDs beoogt natuurontwikkeling en/of beheer. Ze sluiten daarmee aan op gemiddeld bijna vijf van de acht doelen uit de Rijksnatuurvisie. Ongeveer een vijfde van de GDs richt zich indirect op biodiversiteit (bijv. via certificering van producten). Deze sluiten aan op gemiddeld ruim twee doelen.

Voor een derde van de GDs is biodiversiteit meer een nevendoel, omdat deze GDs zich richten op andere duurzaamheidsthema's zoals energie, afval of gezondheid. De potentiële effecten op natuur en biodiversiteit zijn bij deze GDs waarschijnlijk marginaal, ze grijpen namelijk niet aan op de drukfactoren voor natuur en biodiversiteit. Zo is bijvoorbeeld weinig te verwachten van het aanleggen van natuurwandelpaden die vooral bedoeld zijn om de geestelijke gezondheid te bevorderen.

De aansluiting op de beleidsdoelen van de Uitvoeringsagenda Natuurlijk Kapitaal oogt minder substantieel dan bij de Rijksnatuurvisie. Minder dan de helft van de GDs Biodiversiteit sluit aan op (doorgaans slechts één van) deze beleidsthema's. Deze geringere bijdrage komt deels doordat de Uitvoeringsagenda zich naast natuur en biodiversiteit ook richt op ecosysteemdiensten ten gunste van de samenleving en de economie. De Uitvoeringsagenda kent bovendien een sterk internationale focus, terwijl de GD-partijen vooral nationaal zijn georiënteerd. De (slechts) twee GDs die aansluiten op het beleidsthema Waarderen Natuurlijk Kapitaal fungeren als koepel en platform voor een groot aantal afzonderlijke activiteiten. De rijkheid van deze GDs komt in deze analyse minder goed tot uiting.

\section{Concrete bijdrage aan natuurdoelen veelbelovend, maar biodiversiteitkennis is vaak nog een hiaat}

Het effect dat de GDs hebben op de biodiversiteit zelf wordt niet gemonitord, de huidige monitoring is vooral procesmatig ingericht. De analyse die in dit rapport op een vijftal indicatoren is uitgevoerd, wijst in de richting dat het potentieel (positief) effect op natuur en biodiversiteit bij zeker de helft van

\footnotetext{
${ }^{1}$ www.greendeals.nl/thema
} 
de GDs beloftevol is. Deze GDs zijn bovendien actief binnen verschillende aandachtsvelden van natuur, vooral binnen Nederland, zoals het Natuurnetwerk Nederland, het agrarisch gebied, het stedelijk gebied en ecologische verbindingen daartussen. Daarmee komen de GDs tegemoet aan het hoofddoel van de Rijksnatuurvisie, namelijk het realiseren van een 'veelzijdige natuur met een stevige basis'.

Het gaat bij het traditionele natuur- en biodiversiteitbeleid niet om algemene soorten, maar vooral om de zeldzamere, kritische soorten. Vele GDs blijken een bijdrage te leveren aan meer hectares groen (kwantiteit), maar niet per se aan een meer (bio)diverse natuur (kwaliteit). Om ook een kwaliteitsslag te kunnen maken, is het nodig om partijen bij de GD te betrekken met praktische kennis over natuurbeheer en -inrichting. Bij ongeveer de helft van de GDs waarbij groen wordt aangelegd of beheerd, zijn dergelijke kennisinstellingen officieel tekenpartij. Bij de andere helft van de deals zijn deze kennispartijen niet als tekenende partij betrokken. Bovenstaande maakt duidelijk dat er nog het nodige te winnen valt, ook al wordt er een potentiële bijdrage geleverd aan alle beleidsdoelen uit de Rijksnatuurvisie en Uitvoeringsagenda Natuurlijk Kapitaal.

\section{Verdienmodel is niet altijd doorslaggevend, maatschappelijk verantwoord ondernemen is ook belangrijk}

Via GDs kunnen innovatieprocessen op gang komen die via de gebruikelijke beleidsinstrumenten blijkbaar niet of onvoldoende tot ontwikkeling komen. De meerwaarde van GDs lijkt te liggen in de bottom-up benadering vanuit de 'energieke' maatschappij en inspirerende samenwerking tussen GDpartijen uit verschillende sectoren. Dat kan leiden tot een creatieve oplossing van 'oude' knelpunten, het leren en delen van elkaars inzichten, het creëren van nieuwe kansen en uiteindelijk opschaling van de innovatie. Het gaat daarbij niet alleen om het streven naar financiële verdienmodellen. Ook het geven van invulling aan het begrip 'maatschappelijk verantwoord ondernemen' (MVO) blijkt een belangrijke drijfveer voor GD-partijen.

\section{Veel GDs zijn gericht op kwartiermaken en platformfunctie, minder op pilots en opschaling} Het innovatieproces wordt wel verdeeld in de stappen 1) kwartiermaken, 2) demonstreren en 3) opschalen. Eind 2016 was ongeveer een derde van de GDs nog in uitvoering, maar toch tekende zich reeds een scherp onderscheid af tussen de verschillende stappen. Bij alle GDs Biodiversiteit vinden activiteiten plaats die zijn gericht op 'kwartiermaken', bij ongeveer de helft op 'demonstreren' en circa een kwart van de GDs heeft activiteiten gericht op 'opschalen'. Een kwart van de reeds afgeronde GDs heeft bovendien enkel activiteiten ontwikkeld binnen stap 1.

\section{Positie GDs in de beleidsmix: nog weinig 'flow' aanwezig}

De gewenste 'flow' in opeenvolgende stappen van het innovatieproces is bij de meeste GDs (nog) niet opgetreden. Voor het bereiken van 'flow' is het van belang dat beloftevolle GDs, via een vervolg waarin GDs ook weer een rol zouden kunnen spelen, de kans krijgen om het innovatieproces voort te zetten. Daarvoor kunnen andere instrumenten geschikter zijn. Meer in het algemeen zou het goed zijn om aandacht te geven aan de optimale beleidsmix per beleidsdoel, en de rol die GDs daarin kunnen spelen.

Een volgende ronde Green Deals Biodiversiteit kan gerichter worden opgezet, met speciale aandacht voor:

\section{- Formulering GD-doelen}

De doelen van de GDs Biodiversiteit sluiten in meer of mindere mate aan op één of meer beleidsdoelen maar dit zou nog sterker kunnen. In het selectieproces voor het toekennen van GDs zou dat een specifiek aandachtspunt kunnen zijn, eventueel via oproepen voor momenteel nog minder goed belichte doelen uit het biodiversiteitbeleid. Daarnaast verdient het aanbeveling de doelen SMART-er te formuleren, zodat een GD méér is dan een inspanningsverplichting, waarmee het effect op natuur en biodiversiteit naar verwachting uiteindelijk groter is.

\section{- Samenstelling GD-partijen}

In het selectieproces voor het toekennen van GDs zou sterker gekeken kunnen worden naar de samenstelling van de GD-partijen, ofwel invulling van de 'gouden driehoek': overheid, bedrijfsleven en kennisinstellingen. Naast de Rijksoverheid zouden ook lagere overheden ( met een eigen 
verantwoordelijkheid binnen het natuurbeleid) meer betrokken kunnen worden als GD-partij.

Daarnaast zouden kennisinstellingen als GD-partij eigenlijk niet mogen ontbreken, zeker niet waar aan concreet beheer wordt gewerkt. Kennisinstellingen kunnen ook een deel van de monitoring op zich nemen, zodat er een beter beeld kan worden opgebouwd over succesfactoren voor de uiteindelijke uitkomsten. Met dergelijke inzichten kunnen activiteiten worden verbeterd en natuuren biodiversiteitclaims worden onderbouwd.

- Keuze voor inhoudelijke of gebiedsgerichte thema's

Daarnaast kan meer gericht worden gestuurd op biodiversiteitthema's die nu nog niet of ondervertegenwoordigd zijn. Zo kan bijvoorbeeld navolging plaatsvinden van de binnen de GDs Natuur \& Gastvrijheid ontwikkelde aanpak naar Caribisch Nederland. Voor de biodiversiteit van de kustwateren heeft Nederland een grote internationale verantwoordelijkheid, maar binnen de GDs Biodiversiteit komen ze nauwelijks voor. Hetzelfde geldt voor weidevogels, waarvan de populaties al jaren flink verminderen. Een GD-aanpak zoals is opgezet voor akkerbouw in de GD Duurzaam Doorgrond, zou een belangrijke bijdrage kunnen leveren voor het behoud van deze soortgroep.

- Internationale aspecten

Omdat Nederland een belangrijk handelsland is, liggen er verschillende kansen om biodiversiteit ook internationaal via GDs te stimuleren. Denk bijvoorbeeld aan herhaling van de GD-aanpak voor de houthandel, bij andere prioritaire handelsketens zoals vis, palmolie, soja en cacao. Daarvoor worden overigens ook andere samenwerkingsinstrumenten ingezet, zoals het Initiatief Duurzame Handel, of verduurzamingsplatforms die vanuit de sectoren zelf worden geïnitieerd. 



\section{Summary}

Green Deals (GDs) are agreements made between the Dutch government and social partners (such as businesses, NGOs and knowledge institutes) in which the partners come up with innovative solutions for green growth. The partners are invited to solve problems, identify and tackle any sticking points, and design and scale up 'profit from green investment' initiatives.

The various types of GDs are arranged under nine themes, including biodiversity. The brief for this study was to investigate the potential contribution being made by the 41 GDs on Biodiversity (at the end of 2016) to the policy objectives in the Government vision on nature (The Natural Way Forward Government Vision 2014) and the Natural Capital Agenda. The GDs were analysed to identify their relevance to the various policy objectives and their potential for making a real impact on nature and biodiversity, taking a broad view of nature and biodiversity and considering both quantitative and qualitative aspects. The emphasis was mostly on the effects on nature and biodiversity and less on effects for society and the economy, for example in the form of ecosystem services (such as energy from biomass). As the effects on nature are hardly being monitored and these effects often only manifest themselves after several years, the potential effects were assessed. In addition, individuals involved in a number of promising GDs were interviewed to obtain a picture of how the GDs work in practice. The following conclusions can be drawn from the analysis.

\section{Green Deals on Biodiversity make contributions to several government policy objectives}

All the GDs on Biodiversity correspond to one or more of the objectives in the Government vision on nature 2014. The main goal of two-thirds of the GDs is the conservation or development of nature and biodiversity (directly or indirectly). About half the GDs are for habitat creation or restoration and/or management and support on average almost five of the eight objectives of the Government vision. About a fifth of the GDs have an indirect focus on biodiversity (e.g. via certification of products) and contribute on average towards two policy objectives.

Biodiversity is more of a secondary objective for a third of the GDs, because these GDs focus on other sustainability themes such as energy, waste and health. The potential effects of these GDs on nature and biodiversity are probably marginal, because they do not influence the pressure factors for nature and biodiversity. For example, little can be expected from the construction of footpaths through natural areas with the aim of improving mental well-being.

The GDs appear to make a less substantial contribution towards the policy objectives of the Natural Capital Agenda. Less than half the GDs on Biodiversity correspond to these policy themes (and usually to only one). This limited contribution is partly due to the fact that the Natural Capital Agenda covers not only nature and biodiversity, but also ecosystem services that benefit society and the economy. Moreover, the Agenda has a strong international focus, whereas the GD partners are mainly nationally oriented. Just two GDs are relevant to the policy theme Valuation of Natural Capital and they act as a coordinating body and platform for a large number of individual activities. The diversity of activities in these GDs is not fully reflected in the results of this analysis.

\section{Concrete contribution to conservation objectives promising, but biodiversity expertise often lacking}

The effects of the GDs on biodiversity itself are not being monitored, because the current monitoring programme is geared more towards the innovation process. The analysis of the potential (positive) effect on nature and biodiversity carried out for this report indicates that at least half of the GDs is promising. Moreover, these GDs cover a number of different facets of nature conservation, mainly in the Netherlands, such as the National Ecological Network, farmland habitats, urban habitats and the ecological links between them. They therefore support the main objective of the Government vision: providing 'diversity and a solid basis for nature'. 
Traditional nature conservation and biodiversity policies tend to ignore the more common species and focus on the rarer and more critical species. Many GDs create new areas of green space (quantity), but do not necessarily help to increase biodiversity or habitat diversity (quality). To make a qualitative difference it is necessary to bring in parties with practical expertise in conservation management and organisations such as these are official partners in about half the GDs in which green space is created or managed. From the above it is clear that there is still much room for improvement, even though the GDs are making a potential contribution to all the policy objectives in the Government vision on nature and the Natural Capital Agenda.

Profit is not always the decisive factor; corporate social responsibility is also important GDs can stimulate forms of innovation that the usual policy instruments are apparently largely incapable of stimulating. The added value of GDs lies in the bottom-up nature of initiatives from the seedbed of the 'enterprising society' and the inspirational cooperation between GD partners from different sectors. This can lead to creative solutions to 'old' problems, learning from and sharing each other's insights, creating new opportunities and, eventually, to the scaling up of innovations. The aim is not just to develop a workable revenue model; finding ways to put corporate social responsibility into practice is also an important motive for GD partners.

\section{Many GDs are for trailblazing and a platform function and less for pilot projects and scaling up}

The innovation process can be divided into three stages: 1) trailblazing, 2) demonstration and 3) scaling up. At the end of 2016 about a third of the GDs were still ongoing, but a sharp division had already appeared between the three stages. All the GDs on Biodiversity involve 'trailblazing' activities, about half have demonstration activities and about a quarter have scaling-up activities. A quarter of the completed GDs only developed trailblazing activities.

\section{Position of GDs in the policy mix: still little 'flow'}

Most of the GDs have not yet shown the desired 'flow' between the stages of the innovation process (to ultimately provide solutions that, when scaled-up, can help to make the economy greener). To achieve this 'flow' it is important that promising GDs are given an opportunity to take the innovation process forward in a follow-up. GDs could again play a role in this follow-up, but other instruments could be more suitable. More generally, it would be useful to consider what the optimal policy mix would be for each policy objective and the role GDs could play in that mix.

A subsequent round of Green Deals on Biodiversity could be more focused, paying special attention to the following:

- Formulating GD goals

The goals of the GDs on biodiversity correspond in varying degrees to one or more policy objectives, but the tie in could be better. This could be a specific point to be addressed in the selection of GDs, possibly via a call for GDs on Biodiversity policy objectives that have received less attention. It is also recommended to formulate SMARTer goals so that GDs are more than just 'best-efforts obligations' and are more likely to have a greater impact on nature and biodiversity.

- Composition of GD partners

The GD selection process could put more emphasis on selecting proposals with a 'golden triangle' of partners from government, business and the knowledge sector. Besides the national government, local authorities (with their own responsibilities for nature conservation) could be more involved as GD partners. And partnerships should never be without one or more knowledge institutes, certainly when the GD involves practical conservation management. These institutes can also take on some of the monitoring tasks to obtain a better picture of the success factors for the final outcome. Such insights can be used to improve activities and provide a sound evidence base for nature and biodiversity claims.

- Substantive or area-based themes

A conscious decision could be made to select GDs on biodiversity themes that are currently ignored or underrepresented. For example, the approach developed in the GDs on Nature \& Hospitality could be applied to the Caribbean Netherlands. The Netherlands has a major international 
responsibility for biodiversity in coastal waters, but these areas are hardly represented at all in the GDs on Biodiversity. The same goes for meadow birds, the populations of which have declined considerably in recent years. A GD approach similar to that for sustainable arable farming in the GD Duurzaam Doorgrond could make a valuable contribution to the conservation of these species.

- International aspects

Being an important trading nation, the Netherlands has various opportunities to stimulate international biodiversity conservation via GDs, for example by taking the approach in the GD for the timber trade and applying it to other priority trade chains such as fish, palm oil, soy and cocoa. It should be noted that other cooperation instruments are also used in such initiatives, such as the Dutch Sustainable Trade Initiative (IDH) and sustainability platforms set up by the sectors themselves. 



\section{$1 \quad$ Inleiding}

\section{$1.1 \quad$ Achtergrond}

Op 14 april 2016 werd op de Innovation Expo in Amsterdam de 200 ste Green Deal (GD) ondertekend door minister Kamp van Economische Zaken. De eer van de $200^{\text {ste }}$ deal viel ten deel aan de GD Groene Daken fase 2. Dit betrof de $41^{\text {ste }} \mathrm{GD}$ op het thema Biodiversiteit.

Het afsluiten van GDs is een instrument waarmee innovatie gestimuleerd wordt, en waarbij maatschappelijke partners, zoals bedrijven en NGOs, worden uitgenodigd om met ideeën voor groene groei te komen. Zowel om problemen op te lossen, barrières te identificeren en aan te pakken als om 'verdienen met groen' vorm te geven. De vormen die GDs aannemen zijn zeer divers, en kunnen op verschillende manieren bijdragen aan publieke doelen op het vlak van natuur en biodiversiteit. Ook kan op verschillende manieren gebruik worden gemaakt van het natuurlijk kapitaal. Voor de meeste GDs is een formele evaluatie uitgevoerd op verzoek van de Tweede Kamer (Gooskens et al., 2016), maar daarin is slechts beperkt aandacht voor de bijdrage van GDs aan het behalen van de beleidsdoelen voor natuur en biodiversiteit en wat de GDs concreet aan extra natuur en biodiversiteit opleveren.

\subsection{Onderzoeksvraag}

De vraag voor dit onderzoek was wat de GDs Biodiversiteit kunnen bijdragen aan de doelen voor natuur en biodiversiteit ${ }^{2}$.

In Nederland concentreert het biodiversiteitbeleid zich van oudsher op de realisatie van het Natuurnetwerk Nederland en implementatie van het Europese Natura 2000-beleid. Het doel van Natura 2000 is het keren van de achteruitgang van de biodiversiteit. Daarvoor zijn er in Nederland op het land en op zee inmiddels ruim 160 Natura 2000-gebieden aangewezen met een oppervlakte van ruim 1,1 miljoen hectare. Die gebieden worden specifiek beheerd voor het waarborgen van een gunstige staat van instandhouding van ruim 50 verschillende habitattypen en ruim 130 soorten van de Europese Vogel- en Habitatrichtlijn (www.natura2000.nl). Voor Caribisch Nederland is dit biodiversiteitbeleid nog sterk in ontwikkeling (Min. EZ, 2013).

Met het instrument Green Deals worden maatschappelijke partners uitgenodigd om initiatieven en experimenten op te zetten waarmee maatschappelijke betrokkenheid bij het natuurbeleid wordt vergroot. De natuurvisie gaat ervan uit dat het verbreden van het natuurbeleid en het betrekken van nieuwe actoren tot synergie zal leiden met de meer traditionele hoofddoelen. Zoals in de Natuurvisie verwoord: "De betrokkenheid zal niet alleen de maatschappelijk gewaardeerde natuur ten goede komen, maar juist ook de biodiversiteit en de daaraan verbonden nationale en internationale doelen." Namelijk het creëren en verbeteren van goede condities voor biodiversiteit en natuur, het stoppen van het verdere verlies aan natuur en biodiversiteit, en het stimuleren van het duurzaam gebruiken van natuur en biodiversiteit.

\footnotetext{
2 Biodiversiteit is de verscheidenheid van levensvormen op aarde. Met biodiversiteit wordt niet alleen de variatie aan soorten planten, dieren en micro-organismen bedoeld, maar ook de variatie tussen individuen binnen een soort en de variatie in ecosystemen (bron: Naturalis Biodiversity Center).
} 
De doelen van de verschillende GDs Biodiversiteit zijn echter niet zo specifiek gericht op het 'keren van de achteruitgang van de biodiversiteit' zoals hierboven beschreven, maar meer op groen, natuur, vergroening en verduurzaming in algemene zin. Bij sommige GDs Biodiversiteit gaat het ook niet zozeer om biodiversiteit in strikte zin, maar meer om wat de natuur kan bijdragen aan de samenleving en de economie. Het gaat dan om het leveren van bepaalde ecosysteemdiensten, zoals energie uit biomassa.

In dit onderzoek ligt dus de nadruk op de potentiële bijdrage van de 41 GDs Biodiversiteit aan het realiseren van de doelen voor natuur en biodiversiteit, en niet op wat dit vervolgens kan opleveren voor de samenleving en de economie.

\subsection{Werkwijze en leeswijzer}

De doelen voor natuur en biodiversiteit, zoals verwoord in de Rijksnatuurvisie (Min. EZ, 2014) en de Uitvoeringsagenda Natuurlijk Kapitaal (Min. EZ \& Min. I\&M, 2013) vormen de belangrijkste leidraad in de analyse van de GDs Biodiversiteit. De analyses aan de GDs zijn gebaseerd op monitoringsdata in de RVO-database (gegevens per 06-04-2016) en informatie op de website www.greendeals.nl, zoals eindrapportages van afgesloten GDs.

In hoofdstuk 2 Aansluiting van GD-doelen op doelen natuur- en biodiversiteitbeleid zijn de 41 GDs Biodiversiteit getoetst aan de beleidsdoelen uit de Rijksnatuurvisie 2014 (Min. EZ, 2014) en de Uitvoeringsagenda Natuurlijk Kapitaal (Min. EZ \& Min. I\&M, 2013). Daartoe is iedere GD naast de afzonderlijke beleidsdoelen gelegd, waarbij is 'gescoord' of er (in potentie) al dan niet een bijdrage aan een beleidsdoel wordt geleverd. Deze analyse maakt inzichtelijk in hoeverre de ambities van de GDs Biodiversiteit overeenkomen met de ambities van het biodiversiteitbeleid.

Indien een GD een bijdrage levert aan een beleidsdoel gaat het er vervolgens ook om, om inzicht te krijgen in de grootte van die bijdrage. De effecten op natuur en biodiversiteit worden niet of nauwelijks gemeten. Om hier toch inzicht in te krijgen is in dit rapport een vijftal indicatoren opgesteld. Een viertal GD-partijen is vervolgens geïnterviewd, om meer informatie te verzamelen over GDs met een (potentieel) wezenlijk effect op natuur- en biodiversiteit. In hoofdstuk 3 Mate waarin GDs bijdragen aan doelen natuur- en biodiversiteitbeleid worden deze analyse en de resultaten beschreven.

Ten slotte wordt in hoofdstuk 4 GDs Biodiversiteit nader beschouwd beargumenteerd wat de meerwaarde is van de GDs Biodiversiteit en welke verbeterpunten en kansen er liggen om de effectiviteit en efficiëntie van eventueel toekomstige GDs Biodiversiteit te vergroten. 


\section{Aansluiting van GD-doelen op doelen natuur- en biodiversiteitbeleid}

\section{$2.1 \quad$ Inleiding}

In 2011 is de GD-aanpak begonnen. Inmiddels zijn er 200 GDs op negen thema's: water, klimaat, grondstoffen, biobased economy, mobiliteit, energie, voedsel, bouw en biodiversiteit. De meeste deals passen binnen meer GD-thema's. De doelen van de GDs zijn dan ook zeer divers. Voor sommige GDs Biodiversiteit is natuur en biodiversiteit het hoofddoel, voor andere een nevendoel. Zo ook het potentiële effect dat de GDs Biodiversiteit hebben op natuur en biodiversiteit. Om de GDs hierin van elkaar te kunnen onderscheiden wordt in dit hoofdstuk eerst nagegaan of de GD-doelen aansluiten op de beleidsdoelen zoals verwoord in de Rijksnatuurvisie 2014 en de Uitvoeringsagenda Natuurlijk Kapitaal.

\subsection{Doelen natuur- en biodiversiteitbeleid}

Voor het natuur- biodiversiteitbeleid op nationale schaal gaat het vooral om de Rijksnatuurvisie 2014 (Min. EZ, 2014). Met deze visie heeft het kabinet een achttal doelen en acties voor ogen dat voor de komende vijftien tot twintig jaar richting zal geven aan de inzet van de rijksoverheid (figuur 2.1). Die doelen vertegenwoordigen publieke belangen rond huidige en toekomstige natuur, en sluiten in de visie van het kabinet goed aan bij de drijfveren en ambities van betrokkenen partijen in samenleving en economie.

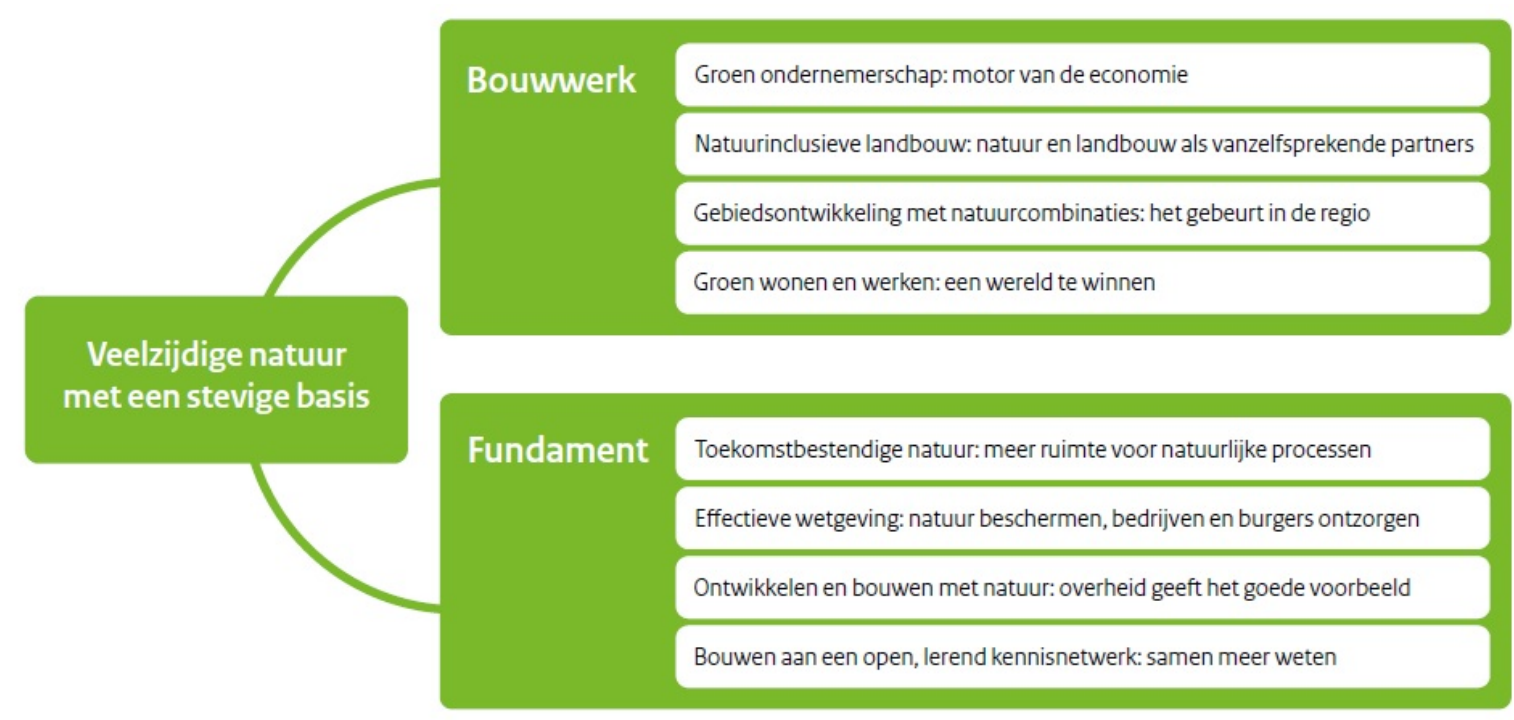

Figuur 2.1 De acht beleidsdoelen uit de Rijksnatuurvisie 2014 die de komende jaren moeten leiden tot een veelzijdige natuur met een stevige basis (Min. EZ, 2014).

Voor het natuur- en biodiversiteitbeleid op internationale schaal gaat het vooral om de Uitvoeringsagenda Natuurlijke Kapitaal (Min. EZ \& Min. I\&M, 2013). De internationale biodiversiteitafspraken van het Biodiversiteitverdrag ( $C B D$ ) en de adviezen van de Taskforce Biodiversiteit en Natuurlijke hulpbronnen vormden de basis voor de Uitvoeringsagenda. Doel van de agenda is om in uiterlijk 2020 veerkrachtige ecosystemen en ecosysteemdiensten te hebben. Naast biodiversiteit moeten deze ook bijdragen aan water- en voedselzekerheid, armoedebestrijding en welzijn. In de agenda staan een viertal samengestelde thema's, waarbij zowel wordt gestreefd naar behoud als duurzaam gebruik van biodiversiteit. Daarmee wil het kabinet versterkt inzetten op de relatie tussen economie en ecologie. De thema's zijn: 
1. Duurzaam produceren en consumeren: duurzame ketens.

2. Duurzame visserij en bescherming van mariene biodiversiteit.

3. Duurzame landbouw en bescherming van biodiversiteit.

4. Het waarderen van natuurlijk kapitaal.

In het vervolg van dit hoofdstuk zullen de 41 GDs Biodiversiteit naast de doelen van de Rijksnatuurvisie en de Uitvoeringsagenda worden gelegd, om na te gaan of de initiatieven van bedrijven en maatschappelijke organisaties hier in potentie op aansluiten en daarmee of de GDaanpak tot effectieve bijdragen aan de overheidsdoelen kan leiden. De GD Biodiversiteit en Economie (GD65) neemt binnen de GDs Biodiversiteit een bijzondere positie in, omdat het een koepel is voor een groot aantal afzonderlijke activiteiten waar een groot aantal bedrijven aan meedoen (zie kader).

\section{Green Deal Biodiversiteit en Economie (GD65)}

De partijen IUCN Nederlands Comité (Stichting), LTO Nederland, MKB Nederland, Taskforce biodiversiteit en VNO-NCW zijn in 2011 de GD Biodiversiteit en Economie gestart. De betrokken partijen streefden daarin naar de vorming van een publiek-private samenwerking (PPS) tussen het Platform Biodiversiteit, Ecosystemen \& Economie (Platform BEE), het bedrijfsleven en de Rijksoverheid. Het gezamenlijke doel was om te werken aan verduurzaming van de economie ('groene groei'). Hiermee kwam een kader tot stand voor de uitvoering van de adviezen van de Taskforce Biodiversiteit en Natuurlijke Hulpbronnen. Deels was dit al ontstaan door bestaande samenwerkingsverbanden, zoals het Initiatief Duurzame Handel (IDH) en het Interdepartementaal Programma Biobased Economy (IPBE).

Eind 2016 is de GD afgerond en is de brochure 'Natuurlijk Kapitaal' uitgebracht (Uitgave van Platform BEE, Ministerie EZ, VNO-NCW en IUCN Nederlands Comité). Hierin staan voorbeelden van meer dan vijftig ondernemers die, samen met het Platform BEE, werk hebben gemaakt van natuurlijk kapitaal; op en om hun bedrijf, in de keten of door te investeren in natuurgebieden. In hoeverre deze initiatieven ook zonder de GD tot stand zouden zijn gekomen is onduidelijk. Wel kan worden gesteld dat door de veelheid en diversiteit aan participerende bedrijven, een bijdrage wordt geleverd aan de verschillende beleidsdoelen of -thema's van zowel de Rijksnatuurvisie 2014 als de Uitvoeringsagenda Natuurlijk Kapitaal.

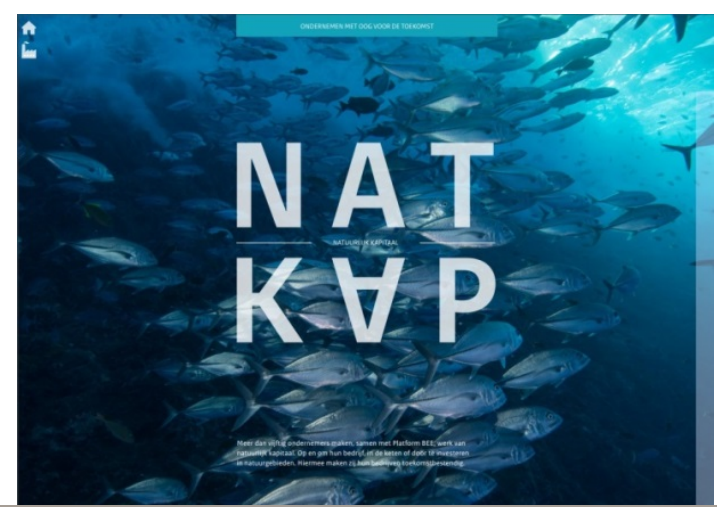

Brochure Natuurlijk Kapitaal

(De Geeter et al. 2016)

\subsection{GDs Biodiversiteit en de Rijksnatuurvisie 2014}

De huidige 41 GDs Biodiversiteit zijn nader geanalyseerd om na te gaan wat de bijdrage is aan de acht doelen en acties uit de Rijksnatuurvisie 2014 (Bijlage 1). Het betreft hier een kwalitatieve analyse, aangezien voor een kwantitatieve analyse de gegevens ontbreken. Gebruikte bronnen betreffen de teksten op website www.greendeals.nl en gegevens in de RVO-database.

\subsubsection{Overeenkomst tussen doelen Rijksnatuurvisie en GDs}

Het blijkt dat de GDs Biodiversiteit aangrijpen/aansluiten op alle acht doelen van de Rijksnatuurvisie. Bijna alle GDs sluiten bijvoorbeeld in meer of mindere mate aan op het beleidsdoel 'Groen ondernemerschap'. Voor de andere beleidsdoelen varieert dat tussen circa de helft van de GDs (Gebiedsontwikkeling met natuurcombinaties) tot een vijfde (natuurinclusieve landbouw) (figuur 2.2). 
De meeste GDs sluiten aan op meer beleidsdoelen tegelijk. Dit wordt hieronder per doel nader toegelicht.

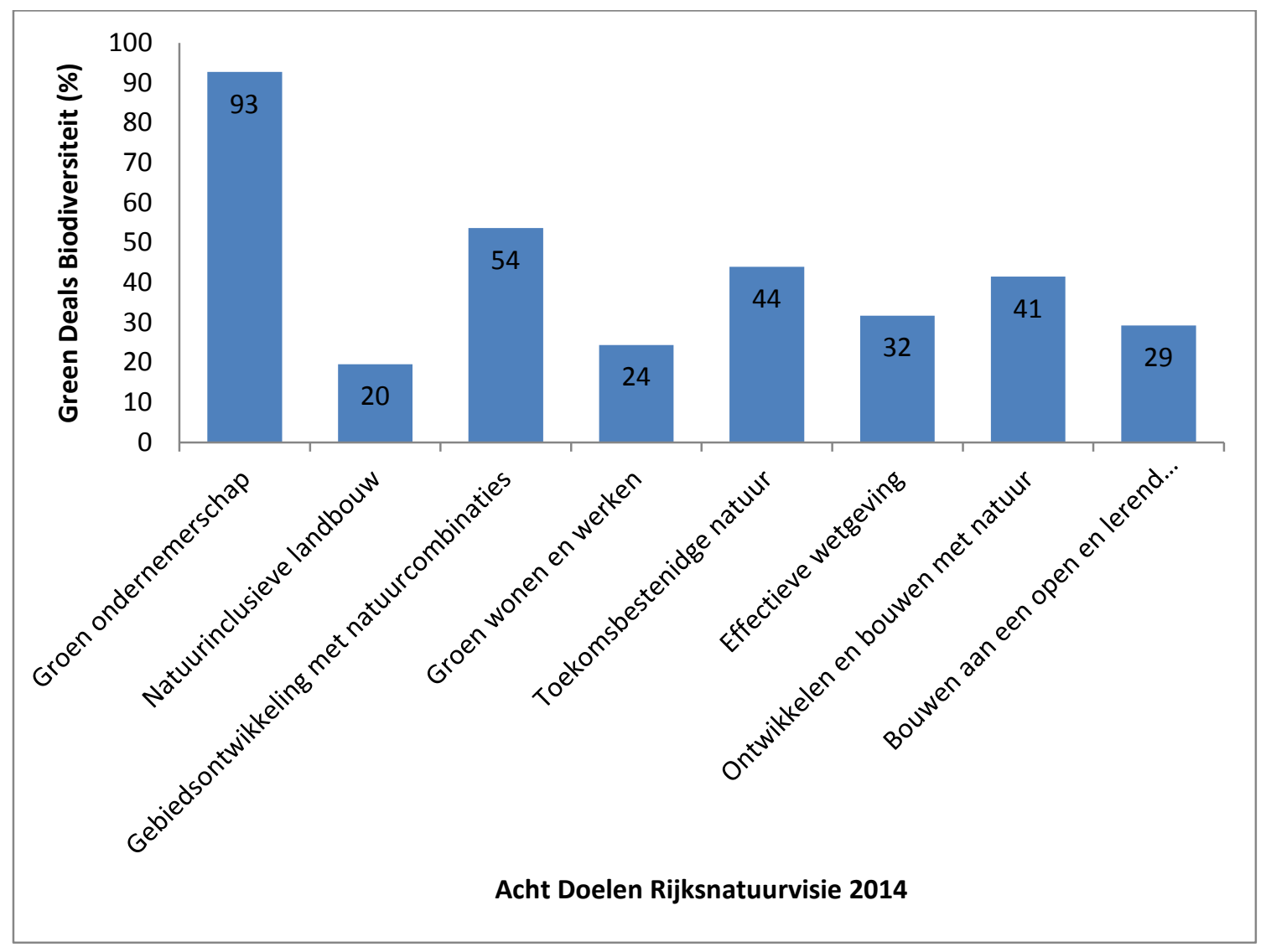

Figuur 2.2 De 41 GDs leveren, in potentie, een bijdrage aan alle acht beleidsdoelen van de Rijksnatuurvisie 2014. Bijna alle GDs sluiten min of meer aan op het beleidsdoel 'Groen ondernemerschap'. Voor de andere beleidsdoelen is dat circa de helft van de GDs ('Gebiedsontwikkeling met natuurcombinaties') of minder.

\section{Groen ondernemerschap: motor van de economie}

Binnen dit doel wil het kabinet dat natuur een geprofileerd onderdeel wordt van groene groei. Dat kan doordat partijen afzonderlijke eigen activiteiten ontwikkelen om natuur te bevorderen. Ook kan het door van natuur een integraal onderdeel van een bedrijfsstrategie of (grensoverschrijdende) productieketen te maken (Min. EZ, 2014). Van de huidige 41 GDs sluiten er 38 in meer of mindere mate aan op dit beleidsdoel (figuur 2.2). Vergroening van de bedrijfsvoering ligt dus doorgaans ten grondslag aan het afsluiten van GDs Biodiversiteit door de betrokken partijen. De resterende drie GDs die hier niet op aansluiten passen feitelijk niet binnen het doel 'Groen ondernemerschap'. Het betreft hier dan ook GDs waarbij de nadruk ligt op het gebruik van groen ten gunste van een ander thema. Bijvoorbeeld de teelt van het niet-inheemse Olifantsgras voor de energieproductie (GD069), of het gebruik van een groene, natuurlijke omgeving als positieve stimulans voor een goede fysieke, psychische en sociale gezondheid (GD139, GD176). Deze GDs dragen niet of nauwelijks actief bij aan de beoogde 'Veelzijdige natuur met een stevige basis'.

\section{Natuurinclusieve landbouw: natuur en landbouw als vanzelfsprekende partners}

De agrobiodiversiteit in Nederland staat vanwege de hoogproductieve landbouw al decennialang zwaar onder druk. Hier valt dan ook relatief veel biodiversiteitwinst te behalen. Binnen het doel 'Natuurinclusieve landbouw' streeft het kabinet naar een beter evenwicht tussen agrarische productie en de ecologische draagkracht van gebieden. Een gezonde bodem en functionele agrobiodiversiteit zijn daarbij onontbeerlijk voor een duurzame productiviteitsverhoging van de landbouw, die bovendien is aangepast aan klimaatverandering (Min. EZ, 2014). Van de huidige 41 GDs sluiten acht deals in meer of mindere mate aan op dit beleidsdoel (figuur 2.2). Met name de GD Duurzaamheid Doorgrond (GD108), die zich richt op een verduurzaming van het akkerbouwbedrijf en duurzame productieketens, is een belangwekkende uitwerking van dit thema. De betreffende GDs hebben 
overigens vrijwel uitsluitend betrekking op akkerbouw, en niet of nauwelijks op veeteelt. Daarmee is de betekenis van Nederland voor bijvoorbeeld weidevogels geen onderwerp dat binnen de afgesloten GDs duidelijk naar voren komt.

\section{Gebiedsontwikkeling met natuurcombinaties: het gebeurt in de regio}

Binnen dit doel wil het kabinet dat economische ontwikkelingen op gebiedsniveau worden gecombineerd met natuurinvesteringen, zoals: natuurontwikkeling in combinatie met hervorming van verblijfsrecreatie, energie-infrastructuur, drinkwaterwinning, klimaatadaptatie. Terreinbeherende organisaties (TBOs) en particulieren zoals landgoedeigenaren, agrariërs en private investeerders moeten in beginsel dezelfde mogelijkheden hebben om gronden voor natuur te verwerven, ontwikkelen en beheren (Min. EZ, 2014). Binnen de GDs zijn vele natuurcombinaties mogelijk en van de huidige 41 GDs sluit ongeveer de helft in meer of mindere mate aan op dit beleidsdoel (figuur 2.2).

\section{Groen wonen en werken: een wereld te winnen}

Het kabinet hecht veel waarde aan natuurinvesteringen in de stedelijke omgeving, vanwege het potentieel positieve effect op het vestigingsklimaat voor bedrijven en werknemers en besparingen op maatschappelijke kosten voor bijvoorbeeld gezondheidszorg, waterbeheer en koeling. Naast groen in de stad is ook de verbinding tussen stad en platteland van belang. Juist omdat de verstedelijking in Nederland alleen maar zal toenemen vindt het kabinet het van belang om de toegankelijkheid van de groene omgeving rond de stad te verbeteren (Min. EZ, 2014). Van de huidige 41 GDs sluiten er tien in meer of mindere mate aan op dit doel (figuur 2.2), zoals de GDs voor groene daken (GD167, GD200), stedelijke natuur en tuinen (GD148, GD193) en natuur langs infrastructuur (GD102, GD196).

\section{Toekomstbestendige natuur: meer ruimte voor natuurlijke processen}

De provincies spannen zich in om het Natuurnetwerk Nederland (NNN) te realiseren, met de Natura 2000-gebieden als belangrijke bouwstenen. Nu het NNN meer samenhang begint te vertonen, en ook de omgeving buiten Natura 2000 met een programmatische aanpak (zoals voor stikstof) meer in beeld komt, kan de aandacht van het natuurbeleid verschuiven van afzonderlijke beschermde soorten en gebieden naar de schaal van landschappen. Daardoor kunnen robuuste, veerkrachtige systemen met ruimte voor natuurlijke processen ontstaan: lage beheerlasten, en haalbare doelen die op natuurlijke wijze mee kunnen bewegen met veranderende omstandigheden zoals door het klimaat. Voor natuur en economie is het aantrekkelijk om natuurinclusief ontwerpen binnen de Europese richtlijnen beter mogelijk te maken (Min. EZ, 2014).

Bij dit doel is er vooral een relatie met GDs die actief zijn binnen het NNN of die daarop aansluiten, zodat de samenhang van het NNN verder wordt versterkt. Denk bijvoorbeeld aan natuurinclusieve (verblijfs)recreatieve bedrijven en landgoederen die merendeels zijn gelegen in de NNN. Maar ook natuurinclusieve landbouw en natuur langs infrastructuur die natuurkernen (nog) beter met elkaar kunnen verbinden. Van de huidige 41 GDs sluit iets minder dan de helft (18 deals) in meer of mindere mate aan op dit doel (figuur 2.2).

\section{Effectieve natuurwetgeving: natuur beschermen, bedrijven en burgers ontzorgen}

Met de Wet natuurbescherming (per 1-1-2017) en de toekomstige Omgevingswet beoogt het kabinet de werkbaarheid van de wetgeving in de praktijk te verbeteren, onnodige lasten voor burgers en ondernemingen te schrappen, beter aan te sluiten bij internationale afspraken, vroegtijdig het natuuren landschapsbelang te betrekken bij gebiedsontwikkeling en grote projecten, actieve beschermingsmaatregelen beter te faciliteren en meer flexibiliteit en ruimte te bieden voor maatwerk. Het perspectief is dat de Wet natuurbescherming zal opgaan in de Omgevingswet (Min. EZ, 2014).

Van de huidige 41 GDs richt ongeveer een derde (13 deals) zich mede op een effectievere natuurwetgeving (figuur 2.2), zoals de GDs voor tijdelijke natuur (GD066), groene groei van recreatieve bedrijven in natuurgebieden (GD037, 103, 104, 105, 106, 107,138) en natuur langs infrastructuur (GD196). Bijzonder resultaat is ook geboekt binnen de GD Duurzaamheid Doorgrond (GD108) waar de Stichting Veldleeuwerik ruim een jaar heeft onderhandeld met het ministerie van EZ en de Europese Commissie. 'Veldleeuwerik' gecertificeerde telers krijgen, vanwege hun grote toewijding voor duurzame landbouw, meer keuzemogelijkheid bij de verplichting om 5\% van het landbouwareaal in te vullen als ecologisch aandachtsgebied. De Veldleeuwerik methode heeft daarmee een definitieve plek gekregen binnen het Europese Gemeenschappelijk Landbouwbeleid (GLB). 


\section{Ontwikkelen en bouwen met natuur: overheid geeft het goede voorbeeld}

Het kabinet heeft als doel om nieuwe grote projecten te combineren met natuur. Een vloeiende overgang tussen bijvoorbeeld natuur en landbouw, tussen platteland en stad en tussen nat en droog biedt kansen voor de beoogde robuuste, veerkrachtige en diverse natuur. Het gaat hier om relatief grote programma's en projecten van het Rijk, zoals het programma Ruimte voor de Rivier en de Natuurambitie Grote Wateren. Maar ook natuurinclusief bouwen en andere overheden en particuliere initiatiefnemers uitnodigen hetzelfde te doen, behoren tot dit doel (Min. EZ, 2014). In dat licht bezien sluiten 17 van de GDs aan op dit doel (fig. 2.2), zoals groene groei van recreatieve bedrijven in natuurgebieden (GD037, 103, 104, 105, 106, 107, 138), de aanleg van groene daken (GD167, 200) en natuur langs infrastructuur (GD102, 196). Zo wordt er bij Rijkswaterstaat geëxperimenteerd om ecologische vraagstukken reeds in de aanbesteding van infrastructurele projecten mee te geven. Snelwegverbreding wordt zo reeds bij projectaanvang binnen een ecologische structuur uitgevoerd (De Vlinderstichting, Wageningen; persoonlijke mededeling, 2016).

\section{Bouwen aan een open, lerend kennisnetwerk: samen meer weten}

Het kabinet wil lerende netwerken stimuleren en ziet daarbij voor zichzelf een rol in het ontsluiten en verspreiden van kennis, en in het stimuleren van het bewustzijn over de eigen invloed op natuur. Om de ambities van het kabinet voor een veelzijdige natuur met een stevige basis waar te maken, zijn veranderingen nodig op het gebied van onderzoek, wetenschap en educatie. Lerende netwerken staan daarbij centraal: netwerken van ondernemers, onderzoekers, overheden, onderwijs, burgers en maatschappelijke organisaties. Hierbij is een speciale rol weggelegd voor de zogenaamde meetnetten waaraan inmiddels zo'n zestienduizend vrijwilligers meewerken. Zij leveren gegevens over populatieveranderingen en de verspreiding van soorten aan Particuliere Gegevensbeherende Organisaties ${ }^{3}$ (PGOs), die via het CBS verwerkt worden tot beleidsinformatie (Min. EZ, 2014).

Alle GDs (100\%) betreffen feitelijk netwerken van diverse partijen die kennis kunnen delen over natuur en/of natuurlijk kapitaal. De meeste GDs zijn door vele partijen ondertekend, zoals de 27 ondertekenaars van de (vooralsnog) laatste GD betreffende Groene Daken (GD200). Toch is slechts in iets minder dan een derde van de van de gevallen (12 deals) sprake van een GD waarbij een onderzoeks- of onderwijsinstelling zoals een universiteit, hogeschool of PGO, officieel partij is in de GD (figuur 2.2). Van alle PGO's is De Vlinderstichting momenteel de enige die al dan niet als tekenpartij betrokken is bij een zevental GDs.

\subsubsection{Aansluiting van afzonderlijke GD-doelen op doelen Rijksnatuurvisie}

De mate waarin de GD-doelen aansluiten op de verschillende doelen uit de Rijksnatuurvisie 2014, verschilt sterk per GD. Om in de diversiteit van GDs een onderscheid te kunnen maken zijn ze verdeeld in drie groepen (Bijlage 1):

1. De 21 GDs (51\%) die via natuurbeheer of natuurontwikkeling in potentie een direct positief effect hebben op natuur en biodiversiteit;

2. De $7 \mathrm{GDs}(17 \%)$ die in potentie een indirect positief effect hebben op natuur en biodiversiteit;

3. De 13 GDs (32\%) waarbij het potentiële effect op natuur en biodiversiteit marginaal is.

\section{Ad. 1 GDs met een potentieel direct positief effect op biodiversiteit}

Deze groep GDs Biodiversiteit betreft de deals waarbij sprake is van natuurontwikkeling en/of beheermaatregelen met een praktisch uitvoerend karakter, zoals aanleg van groen of het maaien of snoeien van vegetatie. Het zijn dan ook allemaal deals waarbij sprake is van een pilot of zelfs opschaling daarvan. Het betreft hier ook een aantal koepeldeals. Zo zijn de zeven GD Natuur \& Gastvrijheid (GD103, 104, 105, 106, 107, 138, 182) feitelijk pilots en een opschaling van de GD Natuurlijk Kapitaal (GD037). Zo ook bij de GDs Groene Daken $(G D 167,200)$ die een opschaling zijn van de GD De Kruideniersgroep, CoP Bedrijven en Biodiversiteit (GD009). De 21 afzonderlijke GDs die het hier betreft sluiten (in meer of mindere mate) aan op gemiddeld bijna vijf van de acht doelen uit de Rijksnatuurvisie (figuur 2.3).

\footnotetext{
${ }^{3}$ Een Particuliere Gegevensbeherende Organisatie (PGO) is een verzamelnaam voor zes stichtingen (bijv. Vlinderstichting) en vier verenigingen (bijv. Zoogdiervereniging en SOVON Vogelonderzoek Nederland) die beschikken over door vrijwilligers verzamelde flora en fauna gegevens in Nederland. Deze PGO's hebben zich verenigd in de Stichting VeldOnderzoek Flora en Fauna (VOFF).
} 


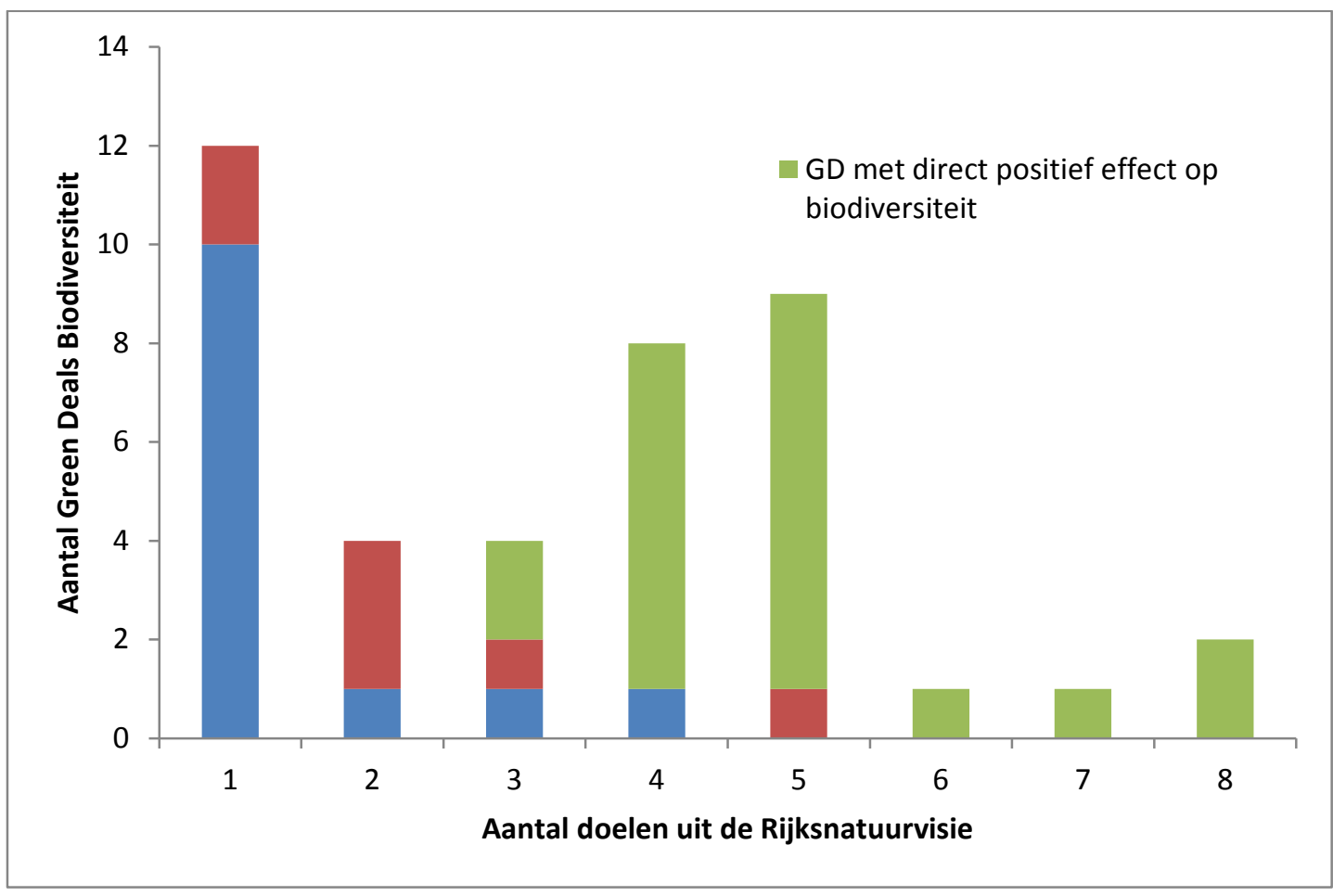

Figuur 2.3 Elke GD Biodiversiteit sluit aan op één tot alle acht beleidsdoelen uit de Rijksnatuurvisie. Voor elk van de 41 GDs is het aantal doelen waarop wordt aangesloten bepaald. Deze figuur laat zien hoeveel GDs Biodiversiteit aans/uiten op 1, 2, 3... tot alle acht doelen uit de Rijksnatuurvisie.

\section{Ad. 2 GDs met een indirect potentieel positief effect op biodiversiteit}

Deze groep van GDs Biodiversiteit betreft de acht deals die zijn gericht op biodiversiteit maar waarbij geen sprake is van een direct effect via natuurontwikkeling of -beheer. Het zijn vooral GDs waarbij de verschillende partijen binnen een sector afspraken maken over vergroening, zoals een biodiversiteitlabel voor agrarische producten (GD071 Biodiversiteit + label), Bevorderen Duurzaam Bosbeheer (GD150) en Samenwerken aan transparantie van natuurlijk en sociaal kapitaal (GD161). De GD Biomimicry (GD070) maakt eigenlijk vooral gebruik van biodiversiteit voor innovatie en commerciële doeleinden. Het indirect positieve effect voor de biodiversiteit betreft hier een op te richten fonds waarvan de gelden aan natuurbescherming kunnen worden besteed. Een vergelijkbaar initiatief geldt voor de GD Duurzaam toerisme (GD175) waarbij een van de tekenpartijen actief wil bijdragen aan natuurherstel in vakantiebestemmingen, door het ondersteunen van biodiversiteitprojecten aldaar.

De zeven afzonderlijke deals die het hier betreft sluiten (in meer of mindere mate) aan op gemiddeld ruim twee van de acht doelen uit de Rijksnatuurvisie (figuur 2.3).

\section{Ad. 3 GDs met (waarschijnlijk) een marginaal effect op biodiversiteit}

Bij deze groep van dertien GDs Biodiversiteit is het effect op biodiversiteit waarschijnlijk marginaal, omdat de focus vooral ligt op andere thema's zoals afvalinzameling (GD171, 172), gezondheid (GD139,176), voedsel (GD083) en energie (GD001, 046, 049, 069, 101, 128 140, 190). Bij een deel van deze GDs levert de natuur/biodiversiteit vooral een (ecosysteem)dienst aan 'de mens', maar deze levert daar relatief weinig voor terug in termen van meer natuur of biodiversiteit. Wel zou een toename in de maatschappelijke waardering van natuur, op termijn kunnen bijdragen aan het behoud daarvan. De effecten op biodiversiteit zijn in deze deals nu toch gekenmerkt als marginaal, neutraal of zelfs negatief. Zo wordt met GD69 olifantsgras geteeld, wat als biomassa moet dienen voor de productie van groene energie. Weliswaar is dit een ecosysteemdienst, maar de teelt van dit nietinheemse gewas, kan wel ten koste gaan van de inheemse agrobiodiversiteit op de betreffende landbouwpercelen.

De dertien afzonderlijke deals die het hier betreft sluiten (in meer of mindere mate) aan op gemiddeld 1,5 van de acht doelen uit de Rijksnatuurvisie (figuur 2.3). 


\subsection{GDs Biodiversiteit en de Uitvoeringsagenda Natuurlijk Kapitaal}

De 'Uitvoeringsagenda Natuurlijk Kapitaal: behoud en duurzaam gebruik van biodiversiteit' kent vier samengestelde thema's en zestien concrete actiepunten (tabel 2.1). Het blijkt dat de doelen van de 41 GDs Biodiversiteit tesamen in meer of mindere mate aansluiten op alle vier beleidsthema's van de Uitvoeringsagenda (Bijlage 1). Het gaat hier echter om minder dan de helft van de GDs (18 deals). De meerderheid van de GDs sluit dus niet aan op de doelen van de Uitvoeringsagenda (figuur 2.4). Daarmee is de bijdrage van de GDs Biodiversiteit aan de Uitvoeringsagenda minder substantieel dan aan de eerder besproken Rijksnatuurvisie (fig. 2.2). Dit komt deels doordat de Uitvoeringsagenda sterk internationaal is georiënteerd, terwijl de GD-partijen zich vooralsnog vooral op Nederland richten. Ook zijn er twee GDs die als koepel en platform fungeren voor een groot aantal afzonderlijke activiteiten: GD161 Samenwerken aan transparantie van natuurlijk en sociaal kapitaal en de circa 50 initiatieven binnen de GD65 Biodiversiteit en Economie (zie kader onder § 2.2). De rijkheid van deze GDs komt in deze analyse minder goed tot uiting.

Daarnaast is de Uitvoeringsagenda ruimer van opzet en richt deze zich niet alleen op natuur en biodiversiteit maar ook op ecosysteemdiensten, bijvoorbeeld energie uit biomassa. Hiermee komen we ook op het terrein van andere GD-thema's, zoals Energie en Biobased Economy. GD 141 Rapportage Duurzaamheid Vaste Biomassa voor Energie, draagt bijvoorbeeld ook bij aan de beleidsthema's van de Uitvoeringsagenda, maar is niet aangemerkt als GD Biodiversiteit. Nadere analyse van alle 200 GDs valt echter buiten deze studie.

De aansluiting van de GDs Biodiversiteit op de vier beleidsthema's van de Uitvoeringsagenda wordt hieronder nader toegelicht.

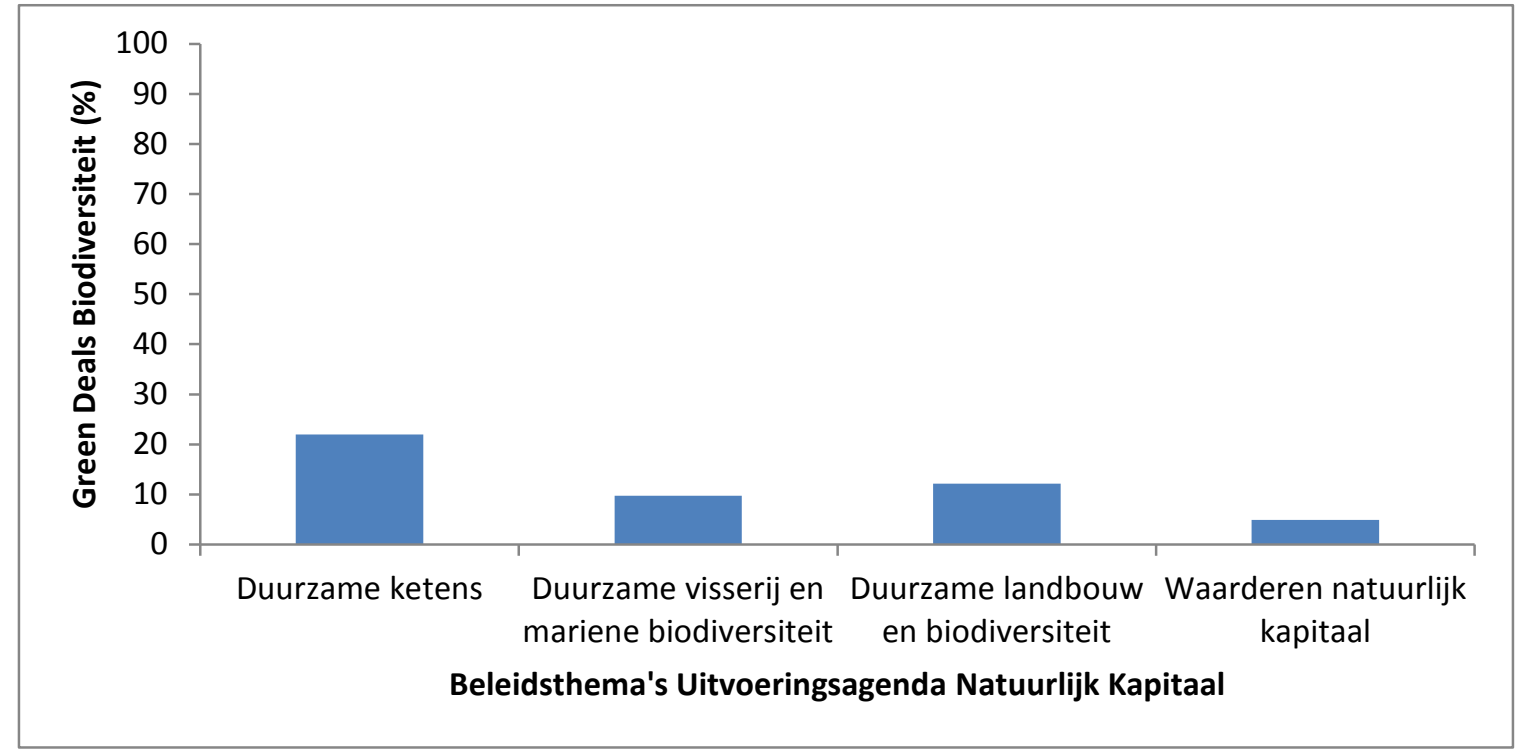

Figuur 2.4 Aantal GDs Biodiversiteit waarvan de GD-doelen (in meer of mindere mate) aansluiten op één van de vier beleidsthema's van de Uitvoeringsagenda Natuurlijk Kapitaal.

\section{Duurzaam produceren en consumeren: duurzame ketens}

De groeiende wereldbevolking en toenemende welvaart leiden tot een toenemende vraag naar agrogrondstoffen, zoals soja en palmolie. Natuurlijke ecosystemen komen daardoor steeds verder onder druk te staan. Daarom is het nodig dat de teelt van gewassen als ingrediënt voor voedsel en veevoer, voor hout en biobrandstoffen wereldwijd zo duurzaam mogelijk plaatsvindt.

Het algemeen streven binnen dit thema is dat agrogrondstoffenketens met een grote impact op biodiversiteit, middels een internationale aanpak in 2020 aan de criteria voor duurzame productie voldoen. 
Negen GDs Biodiversiteit (22\%) sluiten in meer of mindere mate aan op dit thema. De GD Bevorderen Duurzaam Bosbeheer (GD150) sluit zelfs naadloos aan. Zo ook de GD Rapportage Duurzaamheid Vaste Biomassa voor Energie (GD141). Hierin is vastgelegd dat de deelnemende partijen jaarlijks rapporteren over de duurzaamheidskenmerken van vaste houtachtige biomassa die zij inzetten voor de productie van elektriciteit en warmte. GD141 is echter niet één van de 41 GDs Biodiversiteit, maar staat gerangschikt onder andere GD-thema's. De GD Biodiversiteit en Economie (GD65) heeft verschillende initiatieven die aansluiten of onder andere de hout-, koffie- en cacaoketen.

Daarnaast zijn er nog zes GDs Biodiversiteit (GD001, 049, 069, 101, 128, 140) waarbij biomassa wordt geproduceerd en/of vergist voor de energieproductie. Bij Vogelwerende Teelt Olifantsgras (GD069) wordt olifantsgras op landbouwgrond geteeld, dat als biobrandstof kan worden ingezet. Bij de andere GDs is het verband met landbouwgrond, en daarmee de aansluiting bij het thema duurzame ketens, minder duidelijk. Desalniettemin gaat het hier wel om het gebruik van biomassa (bijvoorbeeld bermmaaisel) voor de opwekking van duurzame energie. In hoeverre al deze GDs aan de door de EU vereiste rapportage- en duurzaamheidscriteria voor hernieuwbare energie voldoen is niet duidelijk.

Binnen de GD Biomimicry (GD070) wordt gebruik gemaakt van natuurlijk materiaal voor innovatieve en commerciële doeleinden. Daarmee sluit deze GD aan op dit thema (en is zodoende opgenomen in figuur 2.4 en tabel 2.1). In hoeverre binnen deze GD sprake is van Actiepunt 3: Eerlijke afspraken over gebruik van plantgenetisch materiaal (ofwel ABS - Access Benefit Sharing) wordt echter niet duidelijk uit de beschikbare informatie.

Tabel 2.1 De thema's en concrete actiepunten uit de Uitvoeringsagenda Natuurlijk Kapitaal, evenals de GDs Biodiversiteit die hierop aans/uiten.

\begin{tabular}{|c|c|c|}
\hline $\begin{array}{l}\text { Thema } \\
\text { Uitvoerings- } \\
\text { Agenda NK }\end{array}$ & Actiepunt Uitvoeringsagenda & GD Biodiversiteit (en andere GDs) \\
\hline $\begin{array}{l}\text { Duurzaam } \\
\text { produceren en } \\
\text { consumeren: } \\
\text { duurzame } \\
\text { ketens }\end{array}$ & $\begin{array}{l}\text { 1. Meer hout uit duurzaam beheerde bossen op } \\
\text { de Nederlandse markt } \\
\text { 2. Ronde Tafel Duurzaam Hout brengt } \\
\text { ketenpartijen bij elkaar } \\
\text { 3. Eerlijke afspraken over gebruik van } \\
\text { plantgenetisch materiaal } \\
\text { 4. Biomassa voor elektriciteit en warmte wordt } \\
\text { duurzaam geproduceerd } \\
\text { 5. Natuur wordt op landschapsniveau } \\
\text { beschermd in productiegebieden van } \\
\text { agrogrondstoffen }\end{array}$ & $\begin{array}{l}\text { - Bevorderen Duurzaam Bosbeheer (GD150) } \\
\text { - Groene Groei (GD001) } \\
\text { - DE-on (GD049) } \\
\text { - Vogelwerende Teelt Olifantsgras (GD069) } \\
\text { - Biomimicry (GD070) } \\
\text { - Biomassavergister Winterswijk (GD101) } \\
\text { - Landgoed de Logt (GD128) } \\
\text { - Groene Gevangenis Veenhuizen (GD140) } \\
\text { - Biodiversiteit en Economie (GD65) } \\
\text { - Rapportage Duurzaamheid Vaste Biomassa voor } \\
\text { Energie (GD141) } \\
\text { - Driekwart Duurzame Koffie in Nederland in } 2015 \\
\text { (GD093) }^{5}\end{array}$ \\
\hline $\begin{array}{l}\text { Duurzame } \\
\text { visserij en } \\
\text { bescherming } \\
\text { van mariene } \\
\text { biodiversiteit }\end{array}$ & $\begin{array}{l}\text { 6. Caribisch koraal wordt beter beschermd } \\
\text { 7. Sargassozee wordt beschermd gebied } \\
\text { 8. Plastics in zee worden aangepakt } \\
\text { 9. Gedegradeerde ecosystemen in het mariene } \\
\text { milieu worden hersteld }\end{array}$ & $\begin{array}{l}\text { - Visserij voor een schone zee (GD171) } \\
\text { - Schone stranden (GD172) } \\
\text { - Biodiversiteit Oosterschelde (GD074) } \\
\text { - Biodiversiteit en Economie (GD65) } \\
\text { - Verbetering Afvalbeheer Caribisch gebied } \\
(\text { GD184) }\end{array}$ \\
\hline
\end{tabular}

\footnotetext{
${ }^{4}$ GD141 Rapportage Duurzaamheid Vaste Biomassa voor Energie valt officieel niet onder het GD-thema Biodiversiteit, maar onder de GD-thema's Energie en Biobased economy.

${ }^{5}$ GD093 Driekwart Duurzame Koffie in Nederland in 2015 valt officieel niet onder het GD-thema Biodiversiteit, maar onder de GD-thema's Energie, Energie-efficiency, Mobiliteit, Voedsel

${ }^{6}$ GD184 Verbetering Afvalbeheer Caribisch gebied valt officieel niet onder het GD-thema Biodiversiteit, maar onder de GDthema's Biobased Economy, Duurzame energie, Energie, Energie-efficiency, Grondstoffen, Klimaat.
} 


\begin{tabular}{|c|c|c|}
\hline $\begin{array}{l}\text { Thema } \\
\text { Uitvoerings- } \\
\text { Agenda NK }\end{array}$ & Actiepunt Uitvoeringsagenda & GD Biodiversiteit (en andere GDs) \\
\hline $\begin{array}{l}\text { Duurzame } \\
\text { landbouw en } \\
\text { bescherming } \\
\text { van } \\
\text { biodiversiteit }\end{array}$ & $\begin{array}{l}\text { 10. Gewasbeschermingsmiddelen belasten de } \\
\text { natuur minder } \\
\text { 11. Gedegradeerde ecosystemen op het land } \\
\text { worden hersteld } \\
\text { 12. Biodiversiteit en voedselproductie in balans }\end{array}$ & $\begin{array}{l}\text { - Biodiversiteit+label (GD071) } \\
\text { - Producerend landschap (GD072) } \\
\text { - Samen ondernemen in landbouw en natuur } \\
\text { (GD073) } \\
\text { - Duurzaamheid Doorgrond (GD108) } \\
\text { - Biodiversiteit en Economie (GD65) }\end{array}$ \\
\hline $\begin{array}{l}\text { Het waarderen } \\
\text { van natuurlijk } \\
\text { kapitaal }\end{array}$ & $\begin{array}{l}\text { 13. Een digitale atlas van onze } \\
\text { ecosysteemdiensten } \\
\text { 14. Toepassing van TEEB studies } \\
\text { 15. Natuurlijk kapitaal en economie in de } \\
\text { statistieken } \\
\text { 16. Nederlands bedrijfsleven schat het Natuurlijk } \\
\text { Kapitaal op waarde }\end{array}$ & $\begin{array}{l}\text { - Samenwerken aan transparantie van natuurlijk } \\
\text { en sociaal kapitaal (GD161) } \\
\text { - Biodiversiteit en Economie (GD65) }\end{array}$ \\
\hline
\end{tabular}

\section{Duurzame visserij en bescherming mariene biodiversiteit}

De biodiversiteit van de zeeën en oceanen staat onder druk door onder andere overbevissing en vervuiling. Dat geldt ook voor de Europese zeeën. Het algemeen streven onder dit thema is dat in 2020:

- zowel de keten van kweekvis als de keten van wild gevangen vis voldoen aan internationale criteria op het gebied van duurzaam bestandsbeheer en biodiversiteit;

- de overbevissing binnen EU wateren is gestopt als voorwaarde voor het herstel van vispopulaties;

- het bodemleven en de kwaliteit van het mariene milieu zijn verbeterd;

- voor de bescherming van de biodiversiteit internationaal Marine Protected Areas zijn ingesteld;

- overbevissing en vervuiling van de oceanen wordt voorkomen en waar mogelijk opgeruimd.

Twee GDs Biodiversiteit sluiten aan op actiepunt 8, vanwege het voorkomen en opruimen van afval in zee (tabel 2.1). De GD Biodiversiteit Oosterschelde (GD074) was onder andere gericht op herstel van de mariene biodiversiteit in de kom van de Oosterschelde en sluit daarmee aan op actiepunt 9. Het doel van deze GD is uiteindelijk echter niet gerealiseerd (en officieel is de Oosterschelde ook eigenlijk een binnenwater). Ook de GD Verbetering Afvalbeheer Caribisch gebied (GD184, officieel geen GD Biodiversiteit) kan onder dit thema worden geschaard. Veel afval op de eilanden belandde in de 'oude situatie' door wind en afspoeling uiteindelijk in zee en daarmee uiteindelijk ook op het koraal.

Binnen de GD Biodiversiteit en Economie (GD65) zijn er verschillende initiatieven die vallen onder dit beleidsthema, zoals het terugdringen van plastic afvalstromen, plantaardige alternatieven voor visvoer of visolie en het verwerken van invasieve vissoorten, zoals de Koraalduivel, in restaurants op Curaçao.

\section{Duurzame landbouw en bescherming van biodiversiteit}

Landbouw is wereldwijd en in Nederland de grootste economische 'gebruiker' van landoppervlak. Door de groeiende wereldbevolking en toenemende vraag naar voedsel is de vraag naar landbouwgrond groot en daarmee de druk op biodiversiteit hoog. Landbouw en biodiversiteit kunnen echter niet zonder elkaar: agrarische productie benut de functies van biodiversiteit en andersom heeft de wijze van productie invloed op het functioneren van het ecosysteem als geheel.

Door landbouw in een breder perspectief te plaatsen en naast agrarische productie ook ander functies maatschappelijk te waarderen kan een robuust landbouwsysteem ontstaan. Het algemeen streven binnen dit thema is dat in 2020 sprake is van een duurzaam landbouwkundig beheer, zodat biodiversiteit behouden blijft. Daarnaast dient internationaal te worden bijgedragen aan een duurzaam evenwicht tussen landbouw en biodiversiteit, door het opzetten van voorbeeldprojecten voor geïntegreerde landgebruiksplanning en ecosysteemherstel.

Vijf GDs Biodiversiteit (12\%) sluiten in meer of mindere mate aan op dit thema, omdat wordt gezocht naar een combinatie van landbouw en biodiversiteit (tabel 2.1). 


\section{Het waarderen van natuurlijk kapitaal}

De biodiversiteit levert - direct of indirect - waardevolle diensten aan de maatschappij en economie. Ecosysteemdiensten die ons land levert en gebruikt in bedrijfsprocessen zijn nog beperkt in beeld en worden daardoor nog niet op waarde geschat. Het kabinet ontwikkelt daarom instrumenten om de nationale staat van ecosystemen en hun potentiële diensten in beeld te brengen en onderzoekt de mogelijkheden om deze diensten te waarderen. Het toekennen van economische waarde aan deze diensten helpt inzicht in impact en afhankelijkheid van deze ecosysteemdiensten te verkrijgen en vergroot daarmee de bewustwording. Het algemeen streven is dat in 2020 de Nederlandse ecosysteemdiensten in kaart zijn gebracht, een zichtbare plek hebben in het economisch verkeer en onderdeel zijn van besluitvorming door overheid en bedrijfsleven.

De GD Samenwerken aan transparantie van natuurlijk en sociaal kapitaal (GD161), kan worden gezien als een uitwerking op dit thema. Ook de GD Biodiversiteit en Economie (GD65) valt binnen dit beleidsthema, omdat bedrijven werk maken van natuurlijk kapitaal in en om hun bedrijf. Uiteraard zijn er ook GDs die gebruik maken van natuurlijk kapitaal, zoals ten behoeve van de gezondheid (GD139, 176) of productie van biomassa voor de opwekking van 'groene' energie. Het 'waarderen' van natuurlijk kapitaal is echter geen onderdeel van deze GDs.

\subsection{Samenvatting}

In dit hoofdstuk is nagegaan in hoeverre de ambities of doelen van de GDs Biodiversiteit aansluiten op de beleidsdoelen zoals verwoord in de Rijksnatuurvisie 2014 (Min. EZ, 2014) en de beleidsthema's van de Uitvoeringsagenda Natuurlijk Kapitaal (Min. EZ \& Min. I\&M, 2013). In de Rijksnatuurvisie zijn acht beleidsdoelen geformuleerd, in de Uitvoeringsagenda vier beleidsthema's met zestien actiepunten. Op alle beleidsdoelen en beleidsthema's is er in meer of mindere mate aansluiting vanuit de GDs Biodiversiteit. Meer specifiek als volgt:

\section{Beleidsdoelen Rijksnatuurvisie}

De GDs Biodiversiteit sluiten aan op één of meer van de beleidsdoelen uit de Rijksnatuurvisie 2014. De GDs die via natuurontwikkeling en/of beheer (in potentie) een direct positief effect hebben op natuur en biodiversiteit (circa de helft van de GDs) sluiten aan op drie tot acht doelen uit de Rijksnatuurvisie. De overige GDs, waar sprake is van een (in potentie) indirect of een marginaal effect, sluiten minder 'breed' aan bij deze beleidsdoelen, maar nog steeds is er aansluiting bij één of zelfs meer van de Rijksdoelstellingen. De 'marginale' deals richten zich vooral op andere duurzaamheidsthema's zoals energie, afval, gezondheid en voedsel.

\section{Beleidsthema's Uitvoeringsagenda}

Ongeveer twee vijfde van de GDs Biodiversiteit sluit aan op meestal één van de beleidsthema's van de Uitvoeringsagenda. Daarmee oogt de bijdrage aan Rijksdoelen voor biodiversiteit minder substantieel dan bij de Rijksnatuurvisie. Dit komt deels doordat de Uitvoeringsagenda zich naast natuur en biodiversiteit ook op (andere) ecosysteemdiensten richt, zoals energie uit biomassa. Ook zijn er twee GDs die als koepel en platform fungeren voor een groot aantal afzonderlijke activiteiten. De Uitvoeringsagenda kent daarnaast een sterk internationale focus, terwijl de GD-partijen vooral nationaal zijn georiënteerd. 


\section{$3 \quad$ Het potentiële effect van de Green Deals op natuur en biodiversiteit}

\subsection{Inleiding}

In hoofdstuk 2 is nagegaan in hoeverre de doelen of ambities van de GDs Biodiversiteit aansluiten op de beleidsdoelen, zoals verwoord in de Rijksnatuurvisie 2014 (Min. EZ, 2014) en de Uitvoeringsagenda Natuurlijk Kapitaal (Min. EZ \& Min. I\&M, 2013). De ambities zeggen echter nog niets over het mogelijke resultaat van de GDs, dat wil zeggen het potentiële effect op natuur en biodiversiteit. Een kleine bijdrage aan meer beleidsdoelen kan per saldo uiteindelijk resulteren in een geringer effect dan een grote bijdrage aan één beleidsdoel. Het effect van de GDs op natuur en biodiversiteit wordt niet of nauwelijks gemeten ${ }^{7}$, dus concreet kan hierover weinig worden gezegd. Wel kan een indicatie van het potentiele effect worden verkregen. Daar wordt in dit hoofdstuk verder op ingegaan. Het potentiële effect op natuur en biodiversiteit refereert hier dus niet aan de doelen van de GD zelf. Met andere woorden, een slechte score op het potentiële effect, wil niet zeggen dat sprake is van een mislukte GD.

\subsection{Indicatoren om het potentiële effect op natuur en biodiversiteit te kunnen analyseren}

De effecten op natuur en biodiversiteit worden niet of nauwelijks gemeten. Om een indicatie te krijgen van het potentiële effect kunnen de GDs worden beoordeeld op een aantal indicatoren die verband houden met de kwantiteit en kwaliteit van de te realiseren natuur en biodiversiteit. Deze indicatoren volgen uit bestudering van werking van de 41 GDs en worden voldoende onderscheidend geacht (zonder de pretentie om hierin uitputtend te zijn):

- Indicator 1: Betrokkenheid kennisinstellingen natuur en biodiversiteit en andere GD-partijen.

- Indicator 2: Fase in het innovatieproces.

- Indicator 3: Natuur en biodiversiteit als hoofddoel.

- Indicator 4: SMART-formulering van doelen.

- Indicator 5: Potentie voor opschaling.

\subsubsection{Betrokkenheid kennisinstellingen natuur en biodiversiteit en andere GD-partijen}

Een GD heeft waarschijnlijk de meeste kans van slagen indien de belangrijkste stakeholders met elkaar gaan samenwerken. Welke de belangrijkste stakeholders zijn, verschilt per GD. In de kamerbrief over de evaluatie van de GDs (Min. EZ 2016) wordt gesteld dat "het gemiddelde aantal ondertekenaars van een deal is verdubbeld van 9,9 in 2011 naar 18,6 in 2015. Deze toename komt de slaagkans van deals ten goede omdat zo beter geborgd wordt dat alle stakeholders betrokken zijn."

Wanneer specifiek wordt gekeken naar de 41 GDs Biodiversiteit dan blijkt dat er in de periode 20112012, 28 GDs zijn gestart met gemiddeld zes ondertekenende partijen. Zes van deze 28 deals zijn uiteindelijk voortijdig gestopt, of hebben anderszins (te) weinig resultaat geboekt (deze zes GDs hadden gemiddeld bijna zeven ondertekenaars). Bij de 13 GDs die daarna in de periode 2013-2016 zijn gestart, waren gemiddeld 20 ondertekenaars betrokken. Hiervan is vooralsnog geen enkele voortijdig gestopt.

\footnotetext{
${ }^{7}$ Als gevolg van de GD Tijdelijke Natuur kunnen er Ff-wet vergunningen 'Tijdelijke Natuur' worden aangevraagd. Aan iedere vergunningverlening worden voorwaarden en (mitigerende en/of compenserende) maatregelen gekoppeld. Monitoring van de effectiviteit van die maatregelen is echter eerder uitzondering dan regel (Ottburg en Henkens, 2015).
} 
Het 'aantal ondertekenaars' is echter geen goede indicator. Het gaat vooral om een evenwichtige balans van GD-partijen, waaronder overheid, bedrijfsleven en kennisinstellingen, ook wel de gouden driehoek genoemd (Van Vliet en Beers, 2011). Voor het effect op natuur en biodiversiteit is het betrekken van kennispartners vaak belangrijk, omdat het niet evident is wat gunstige condities zijn voor natuur- en biodiversiteitwinst. Het gaat niet alleen om de aanleg van hectares groen (natuurkwantiteit), maar ook om de wijze waarop een gebied wordt ingericht (onder andere situering van ecologische corridors in het landschap) en hoe dit groen wordt beheerd (natuurkwaliteit). Vele bedreigde, vaak kritische soorten zijn veeleisend voor hun leefomgeving. Met een uitgekiende inrichting en natuurbeheer kan hierop worden ingespeeld. Het gaat dan om een combinatie van maatregelen, zoals de waterhuishouding en het maairegime. De gemiddelde sterfte van rupsen, vlinders en andere insecten door maaien bijvoorbeeld, is met de gebruikelijke klepelmaaier groter dan $80 \%$, maar met een messenbalk minder dan $10 \%$. Ook de maaifrequentie, maaihoogte, maaiselafvoer en het gefaseerd maaien (en ongemoeid laten) van stukken terrein, dragen in sterke mate bij aan de biodiversiteitwaarde (Wallis de Vries, 2016).

Zonder een dergelijke op kritische soorten afgestemde inrichting en beheer, zal een terrein vooral het leefgebied worden van algemene soorten. De potentie van een terrein voor natuur en biodiversiteit blijft dan onderbenut. Deze praktische natuurbeheer- en soortenkennis is vooral aanwezig bij terreinbeherende organisaties (TBO's) zoals Staatsbosbeheer, Natuurmonumenten, de Landschappen en Particuliere Gegevensbeherende Organisaties (PGO's), zoals de Vlinderstichting, Zoogdiervereniging, Ravon (reptielen, amfibieën en vissen), Sovon (vogels) of Floron (planten).

Uit analyse van de 21 GDs Biodiversiteit, waarbij sprake is van de aanleg en/of het beheer van natuur (GDs met direct effect op biodiversiteit; zie §2.2.2), blijkt dat in ongeveer de helft van de gevallen een TBO of PGO betrokken is (de kennis en kunde van natuurinrichting en -beheer van eventuele andere betrokken partijen is niet duidelijk); bij de andere helft is een dergelijke kennispartner in ieder geval niet als ondertekenaar betrokken bij de deal. Opvallend is ook dat van alle PGOs alleen de Vlinderstichting als tekenpartij bij GDs betrokken is. Dit wijst in de richting dat dat de kansen voor natuur en biodiversiteit in veel GDs waarschijnlijk onderbenut worden. Voor wat betreft het effect op natuur en biodiversiteit missen deze GDs belangrijke belanghebbenden.

\subsubsection{Fase in het innovatieproces}

Een belangrijke functie van het instrument GDs is te zorgen voor vernieuwing. Om na te kunnen gaan waar de verschillende GDs zich in het innovatieproces bevinden en welke stappen daarbij zijn gezet, kan gebruik worden gemaakt van het processchema in figuur 3.1. Dit schema is specifiek opgesteld voor de evaluatie van de GDs Circulaire Economie (Ganzevles et al., 2016), maar kan ook inzicht geven in de voortgang van de GDs Biodiversiteit. In het schema worden drie stappen onderscheiden: 1) kwartier maken, 2) demonstreren en 3) opschalen.

De meeste GDs starten met stap 1 'kwartier maken', maar GDs kunnen ook op een ander moment in het innovatieproces worden afgesloten. Zo zijn de zeven icoonprojecten van de Gastvrijheidssector (GD 103, 104, 105, 106, 107, 138, 182) feitelijk pilots (stap 2) van de GD Natuurlijk Kapitaal (GD037). Ook in de opschalingsstap (stap 3) kunnen GDs worden afgesloten. Zo werkten, voorafgaand aan de GD Duurzaamheid Doorgrond (GD108), circa 100 akkerbouwers in Flevoland aan een duurzame bedrijfsvoering volgens de systematiek van Stichting Veldleeuwerik. Omdat men het duurzaam beheerde akkerbouwareaal wilde opschalen, ook buiten Flevoland, is de betreffende GD afgesloten.

Figuur 3.2 geeft de verdeling van de GDs Biodiversiteit in deze drie stappen. Hieruit blijkt dat er bij alle GDs acties zijn die vallen onder 'Kwartier maken' (stap 1). Voor circa de helft van de GDs zijn er acties die vallen onder stap 2 'Demonstreren' en bijna een kwart onder stap 3 'Opschalen'. Van de 41 GDs blijkt ongeveer twee derde (29 deals) te zijn afgerond (stand van zaken eind 2016). De rest was eind 2016 nog in uitvoering en kan in het innovatieproces nog stappen zetten (Bijlage 1). 


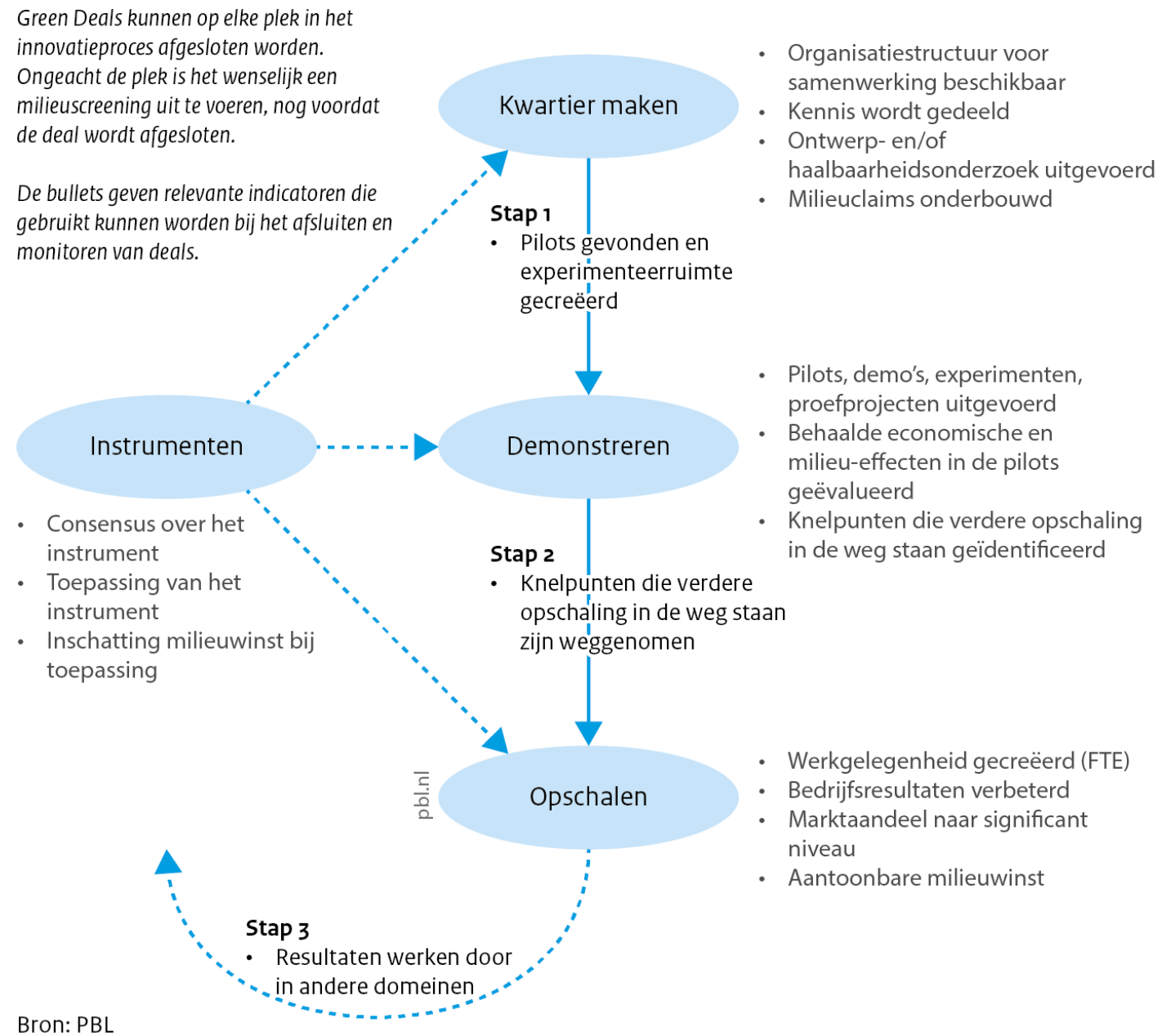

Figuur 3.1 Processchema Green Deals (Ganzevles et al., 2016).

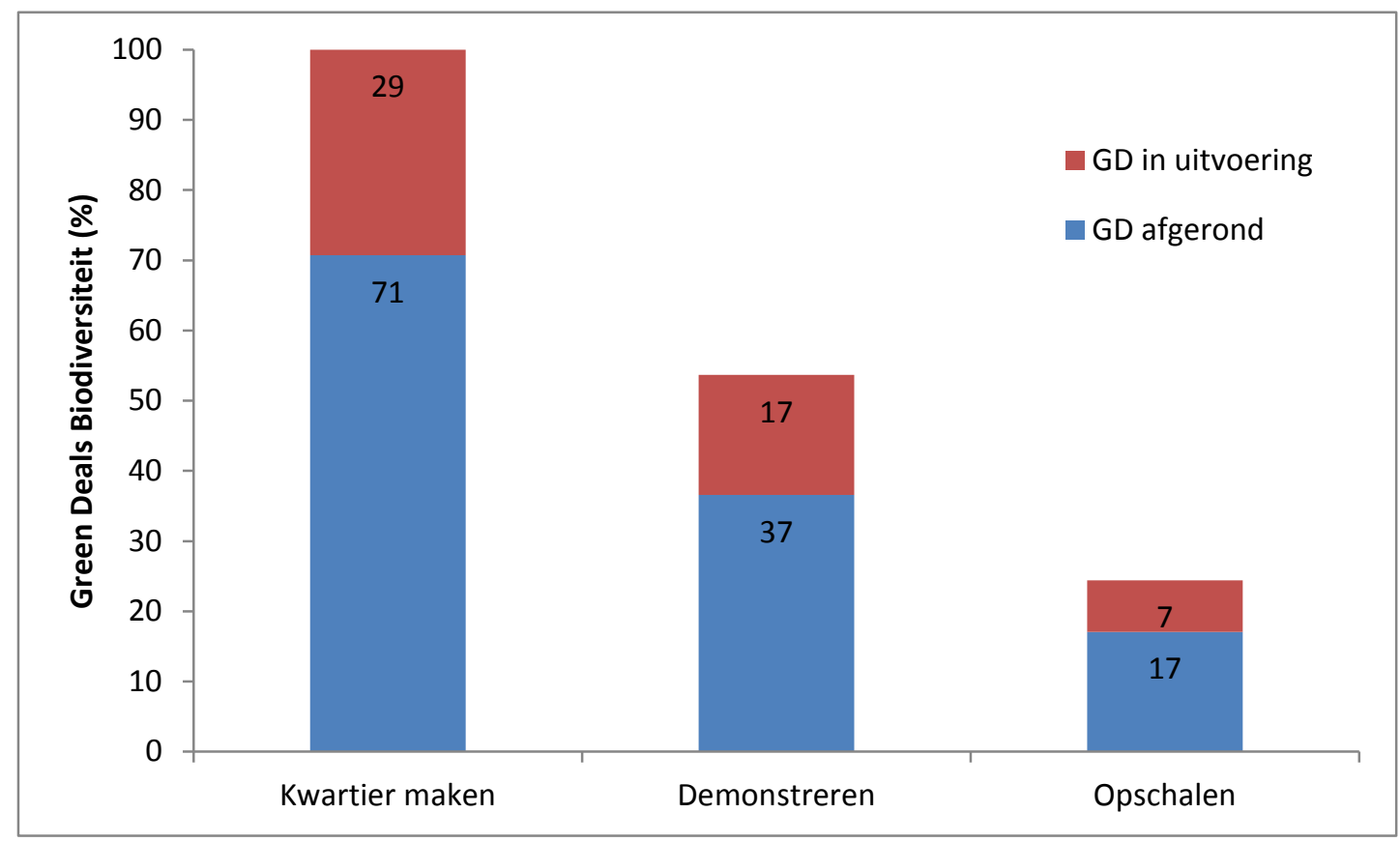

Figuur 3.2 Verdeling van afgeronde en nog in uitvoering zijnde Green Deals Biodiversiteit in de stappen Kwartier maken, Demonstreren en Opschalen. 


\section{Kwartiermaken}

De ondertekening van een GD markeert niet alleen het begin van een samenwerkingsproces, maar ook het eind van een onderhandelingsproces met de verschillende dealpartijen. Het proces om tot de GD Bevorderen Duurzaam Bosbeheer (GD 150) te komen heeft bijvoorbeeld anderhalf jaar geduurd en uiteindelijk waren er 27 organisaties officieel partner. Feitelijk is het door alle partijen ondertekende dealdocument een eerste tastbaar resultaat van elke GD (Schultz et al., 2016).

Vervolgens vinden er binnen elke GD acties plaats om die samenwerking te implementeren, het zogenaamde kwartiermaken. Dit zijn acties zoals netwerkevents binnen de GD Biomimicry (GD070), publicatie van essays binnen de GD Het Landgoedbedrijf (GD075) of het opzetten van een governance-structuur met aanstelling van een secretaris en organisatie van platform- en stuurgroepbijeenkomsten binnen de GD Bevorderen Duurzaam Bosbeheer (GD150).

Van de 29 deals die zijn afgerond, is ongeveer de helft in het innovatieproces uiteindelijk niet gekomen tot een demonstratie- of pilotfase. Bij zes daarvan (15\% van totaal) bleek de GD uiteindelijk niet realiseerbaar, zoals de biogasinstallaties op Landgoed de Logt (GD128) en bij Winterswijk (GD128) en het doorlaatmiddel in de Oesterdam, dat de natuur- en waterkwaliteit van de Oosterschelde had moeten stimuleren (GD074 Biodiversiteit Oosterschelde). Ook de GDs Land van Bezinning Noord-Holland (GD103) en Zuid-Holland (GD104) zijn uiteindelijk niet gerealiseerd, omdat de gastvrijheidsondernemer afhaakte. Deze GDs waren als concrete pilots geïnitieerd (stap 2), maar verder dan acties behorende tot kwartiermaken, is het niet gekomen. Dit geef aan dat het ruimte geven aan experimenteren met innovatieprocessen niet altijd leidt tot positieve resultaten op de korte termijn. Vanuit innovatieperspectief op langetermijn is het belangrijk dat er ook ruimte is voor 'vallen en opstaan'; nieuwe projecten kunnen weer leren van eerdere deals die mogelijk minder succesvol waren.

\section{Demonstreren}

Circa de helft van alle GDs Biodiversiteit (54\%) heeft ook een pilotfase (stap 2 Demonstreren). Dat percentage zal waarschijnlijk nog toenemen, omdat circa een derde deel van de GDs nog in uitvoering is. De in 2015 gestarte GD 1000 hectare nieuwe stedelijke natuur (GD193) en de in 2016 gestarte GD Infranatuur (GD196) bijvoorbeeld zullen in het innovatieproces naar verwachting nog kunnen doorontwikkelen naar stap 2 en wellicht stap 3.

In stap 2 zitten ook GDs die zijn gestart in stap 2, zoals de eerdergenoemde GDs Natuur \& Gastvrijheid (GD105, 106, 107, 138, 182). Dit zijn pilots van de GD Natuurlijk Kapitaal (GD037) waarvoor stap 2 ook de eindstap betreft. Nieuwe pilots betreffen in dit geval vooral een verdere opschaling van GD037.

\section{Opschalen}

Zolang (eventuele) belangrijke knelpunten niet zijn weggenomen, kan feitelijk niet met opschaling worden begonnen. Binnen de GD Bevorderen Duurzaam Bosbeheer (GD150) bijvoorbeeld zijn oplossingen aangedragen voor het grote prijsverschil tussen gecertificeerd tropisch hout en het goedkopere niet-gecertificeerde hout, waarbij het prijsverschil kan oplopen tot $30 \%$. Herziening van het belastingstelsel en/of minder heffing van invoerrechten voor duurzame producten, zijn mogelijke oplossingsrichtingen die echter politiek gevoelig liggen. Weliswaar wordt als vervolg op deze GD een nieuw internationaal MVO-convenant afgesloten, maar zolang dit knelpunt niet is weggenomen, blijft de kans op opschaling vermoedelijk laag. De overheid probeert wel een gelijk speelveld te creëren door regelgeving voor het weren van illegaal geoogst hout, wat met name geldt voor hout uit tropische gebieden.

Bij bijna een kwart van alle GDs Biodiversiteit (24\%) is sprake van stap 3 Opschalen. Dat kunnen er meer worden, aangezien een derde deel van de deals nog in uitvoering is. De afgeronde GD Tijdelijke Natuur (GD066) waarmee natuurwaarden zich tijdelijk kunnen ontwikkelen op toekomstige bouwterreinen, heeft bijvoorbeeld geresulteerd in een gelijknamige stichting, een toenemend aantal ontheffingsaanvragen en inmiddels 3000 ha tijdelijke natuur. Ook de nog in uitvoering zijnde GD Duurzaamheid Doorgrond (GD108) blijft groeien met een toenemend aantal participerende akkerbouwers die hun bedrijfsvoering willen verduurzamen. Ook bij de GD Biodiversiteit en Economie 
(GD 65) is sprake van opschaling. Meer dan 50 ondernemers hebben in samenwerking met het Platform BEE inmiddels werk gemaakt van natuurlijk kapitaal op en om hun bedrijf, in de keten of door te investeren in natuurgebieden.

Nieuwe verdienmodellen kunnen helpen om tot de gewenste opschaling te komen. Bij een verdienmodel gaat het om het vinden van een positieve balans tussen opbrengsten en investeringen. Het gaat hierbij niet alleen om economische maar ook om maatschappelijke verdienmodellen. De GD167 Groene Daken bijvoorbeeld leverde liefst vijf potentiële verdienmodellen op. Zoals het verdienmodel Ecosysteemherstel dat zich richt op het bundelen van groene daken in een gebiedsgerichte aanpak, wat aantrekkelijk kan zijn voor projectontwikkelaars en grotere investeerders. Of het verdienmodel Differentiatie belastingen (rioolheffing, waterschapsbelasting, OZB) dat zich richt op de baten op het gebied van hemelwater(berging) en/of ecosysteemversterking. Dit kan doordat gemeenten en waterschappen worden beloond met een korting op gebouwgerelateerde belastingen.

Niet bij elke GD is echter meteen sprake van een verdienmodel. Vaak kan een GD ook worden aangemerkt als een vorm van maatschappelijk verantwoord ondernemen. Binnen de GD Infranatuur bijvoorbeeld streven de partijen (waaronder ProRail, Gasunie, TenneT, Vitens en Heijmans) ernaar om biodiversiteit onderdeel uit te laten maken van hun beheer. Vergroening van bedrijventerreinen met nieuwe natuur levert veel positieve feedback en bewustwording op. Het vergroot het draagvlak voor andere verduurzamingsmaatregelen binnen de organisatie (De Vlinderstichting Wageningen, pers. mededeling, 2016). Vermindering van onderhoudskosten als gevolg van een ecologischer beheer kan wellicht een verdienmodel blijken te zijn, maar dit lijkt niet de enige drijfveer te zijn om in een GD te participeren.

\subsubsection{Natuur en biodiversiteit als hoofddoel}

Voor de mate waarin een GD bijdraagt aan de biodiversiteitdoelen maakt het doorgaans uit of biodiversiteit voor de betreffende deal een hoofd- of een nevendoel is. Deze analyse is reeds voor $\S 2.2 .2$ uitgevoerd.

Voor twee derde van de GDs ( $n=28$ ofwel $68 \%$ ) kan natuur of biodiversiteit direct of indirect worden beschouwd als een (van de) hoofddoel(en). Bij een derde van de GDs echter ( $n=13$, ofwel $32 \%$ ) is natuur of biodiversiteit slechts een nevendoel, omdat ze vooral zijn gericht op andere duurzaamheidsthema's zoals energie $(n=8)$, afval $(n=2)$, gezondheid $(n=2)$ en voedsel $(n=1)$. Het effect op natuur en biodiversiteit is in deze GDs waarschijnlijk geringer of marginaal.

\subsubsection{SMART-formulering van doelen}

Afrekenbare doelen vergroten de kans dat deze doelen ook worden bereikt, omdat partijen elkaar daar onderling op kunnen aanspraken en ook andere partijen in de samenleving dat kunnen doen. Vaak worden afrekenbare doelen SMART geformuleerd: specifiek, meetbaar, acceptabel, realistisch en tijdgebonden. SMART doelen maken het ook beter mogelijk om na te kunnen gaan of een gemeten effect het gevolg is van de betreffende GD. Het formuleren van SMART-doelen is echter niet kenmerkend voor GDs. Dit komt vooral doordat de GD-aanpak is gericht op het stimuleren van dynamiek in de samenleving en niet zozeer op afrekenbare resultaten. Over SMART in relatie tot de GD-doelen kan het volgende worden opgemerkt:

- Specifiek: de GDs hebben over het algemeen meer doelen die al dan niet specifiek zijn geformuleerd. De GD108 Duurzaamheid doorgrond bijvoorbeeld heeft als concreet doel dat de methode Veldleeuwerik in 2014 is opgeschaald naar 1.000 telers, maar ook als meer abstract doel dat in 2014 de meerderheid van de toonaangevende bedrijven aangesloten en actief is in de methode Veldleeuwerik, zonder dat duidelijk wordt om hoeveel en welke bedrijven dat dan zou moeten gaan. De verhouding tussen specifiek en abstract geformuleerde doelen binnen de GDs is min of meer gelijk.

- Meetbaarheid: de mate waarin de gestelde doelen worden of zijn behaald, blijkt niet altijd zo eenvoudig in beeld te brengen. Vooral vanwege het ontbreken van een helder geformuleerde uitgangssituatie of referentiewaarde. Het is veelal onduidelijk in welke mate een gemeten of vermeend effect (als het al wordt gemonitord) aan de GD kan worden toegeschreven. 
- Acceptabel: er mag worden aangenomen dat alle in de GDs genoemde doelen acceptabel zijn, aangezien ze niet top-down zijn opgelegd, maar bottom-up door de deelnemende partijen zelf zijn geformuleerd. Ook heeft de overheid de deal goedgekeurd.

- Realistisch: de doelen lijken in eerste instantie realistisch. Enerzijds omdat doelen vaak abstract zijn geformuleerd in termen als meer of minder (i.p.v. dat er een boven- of ondergrens is aangegeven), anderzijds omdat ze door de deelnemende partijen zelf zijn geformuleerd. Toch bestaat juist bij innovatieprocessen het 'gevaar' dat allerlei ambities worden overdreven om partijen in beweging te krijgen. Dat lijkt ook het geval bij de GD Duurzaamheid doorgrond (GD108). Deze had als doel om de methode Veldleeuwerik op te schalen naar 1.000 telers in 2014. Eind 2016 waren dat er echter nog 'slechts' 390. Nog steeds bijna een vervierdubbeling van de uitgangssituatie, maar wel ruim 600 minder dan het doel van twee jaar daarvoor.

- Tijdgebonden: de GDs zijn over het algemeen tijdgebonden, aangezien de doelen overwegend binnen de looptijd van de deal dienen te worden behaald. Ook kunnen ze nader worden gespecificeerd in een vervolgdeal.

\subsubsection{Potentie voor opschaling}

Potentie voor opschaling is een belangrijke indicator om het potentiële effect op natuur en biodiversiteit te kunnen bepalen. De GD moet idealiter een innovatie zijn die breed kan worden uitgerold over Nederland of daarbuiten. Bijvoorbeeld een GD Infranatuur (GD196) die in potentie langs duizenden kilometers infrastructuur in Nederland kan worden opgeschaald, een GD Duurzaamheid Doorgrond (GD108) waar duizenden akkerbouwers zich bij kunnen aansluiten of de cases binnen de Natuur en Gastvrijheidssector die als voorbeeld kunnen dienen voor duizenden andere gastvrijheidsondernemers. Sommige GDs zijn echter dermate uniek dat de potentie voor opschaling beperkt is, zoals een beoogde doorlaat voor zoet water in een van de Oosterscheldedammen (GD074 Biodiversiteit Oosterschelde).

\subsection{Potentieel effect van de GDs op natuur en biodiversiteit}

Een analyse (figuur 3.3) van de score van de 41 GDs Biodiversiteit op de hierboven beschreven vijf indicatoren laat zien dat het potentiële effect op natuur en biodiversiteit bij bijna de helft van de GDs beperkt lijkt (score op maximaal twee van de vijf indicatoren; zie Bijlage 1 voor de scores per GD). Het potentiële effect bij de overige GDs lijkt beloftevol (score op minimaal drie indicatoren). De zes GDs die voortijdig zijn gestopt zijn per definitie tot de groep 'beperkt' gerekend.

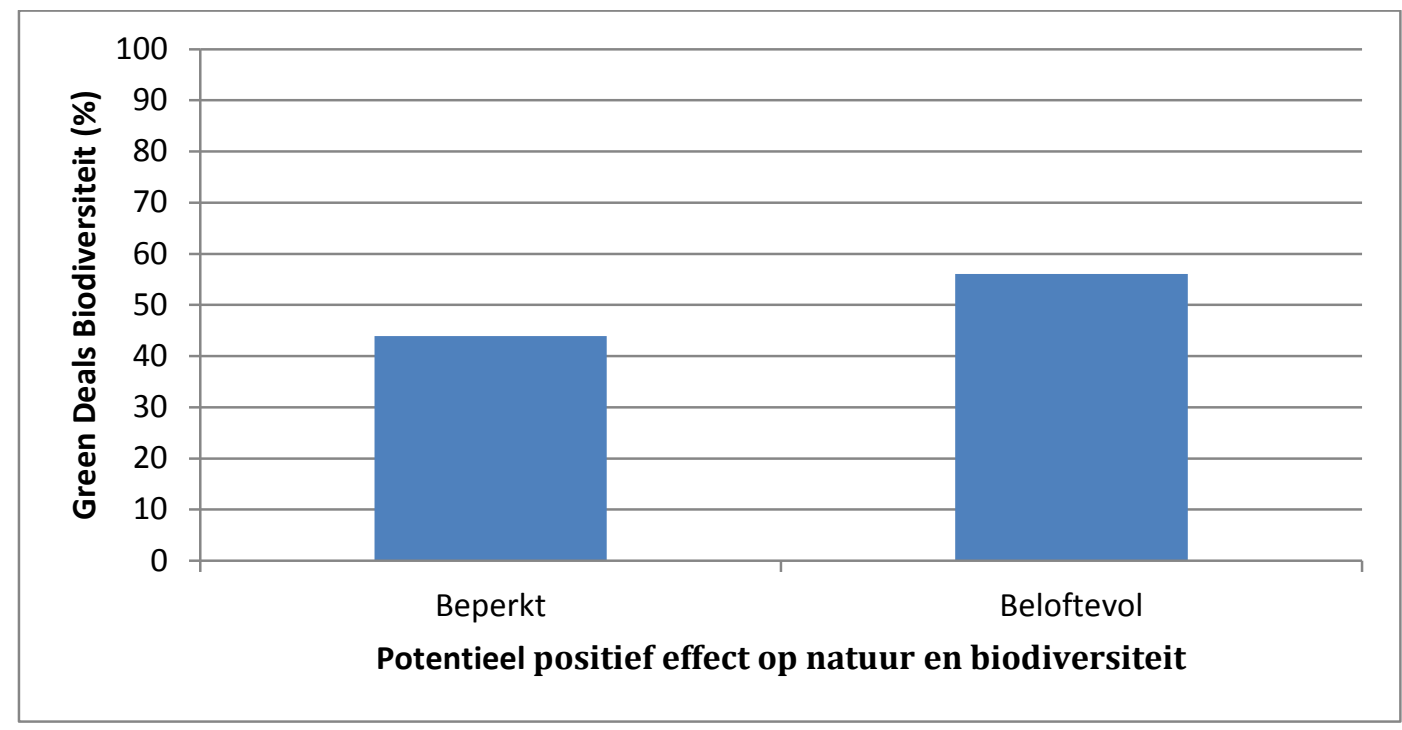

Figuur 3.3 Mate waarin de GDs Biodiversiteit in een potentieel (positief) effect hebben op natuur en biodiversiteit op basis van een analyse op vijf indicatoren: beperkt (score op maximaal twee indicatoren), beloftevol (score op minimaal drie indicatoren). 
Omdat de desk-analyse van het potentieel effect op natuur en biodiversiteit slechts een eerste indicatie geeft, zijn vier aanvullende interviews gehouden met GD-partijen uit het veld. Aangezien de Rijksnatuurvisie streeft naar een Veelzijdige natuur met een stevige basis (zie figuur 2.1) is gekozen voor beloftevolle GDs die van toepassing zijn op verschillende biodiversiteitthema's: biodiversiteit van het Natuurnetwerk Nederland, agrarisch gebied, stedelijk gebied en ecologische verbindingen. Omdat de Uitvoeringsagenda een meer internationaal karakter heeft is ook een GD-partij opgenomen die betrokken is bij een GD op een internationaal biodiversiteitthema (tabel 3.1).

Tabel 3.1 Geïnterviewde GD-partijen en de GDs waarbij ze betrokken zijn.

\begin{tabular}{lll}
$\begin{array}{l}\text { Interview } \\
\text { GD-partij }\end{array}$ & $\begin{array}{l}\text { Thema natuur en } \\
\text { biodiversiteit }\end{array}$ \\
$\begin{array}{l}\text { Stichting Innovatie Recreatie } \\
\text { en Ruimte (STIRR) }\end{array}$ & $\begin{array}{l}\text { Natuurnetwerk } \\
\text { Nederland }\end{array}$ & $\begin{array}{l}\text { Natuurlijk Kapitaal (GD037) met zeven icoonprojecten } \\
\text { (GD103, 104, 105, 106, 107, 138, 182). }\end{array}$ \\
\hline Stichting Veldleeuwerik & Agrarisch gebied & Duurzaamheid Doorgrond (GD108) \\
\hline Vlinder-stichting & Stedelijk gebied & Tijdelijke Natuur (GD066) \\
& & $\begin{array}{l}\text { Levende duurzame buitenruimtes (GD148) } \\
\text { Groene Daken (GD167, 200) }\end{array}$ \\
\hline Vlinderstichting & & 1000 hectare nieuwe stedelijke natuur (GD193) \\
\hline $\begin{array}{l}\text { Koninklijke Vereniging Van } \\
\text { Nederlandse }\end{array}$ & Ecologische verbindingen & Blauwzaam lint (GD102) \\
Houtondernemingen (VVN) & internationaal & Bevorderen duurzaam bosbeheer (GD150) \\
\hline
\end{tabular}

De deals worden in relatie tot de indicatoren hieronder nader toegelicht. Daarbij wordt ook gebruik gemaakt van de interviewverslagen (Bijlage 2).

\subsubsection{Natuur en biodiversiteit in het Natuurnetwerk Nederland}

\section{Natuurnetwerk Nederland}

Het Natuurnetwerk Nederland (NNN), voorheen de 'Ecologische Hoofdstructuur' (EHS), is een netwerk van bestaande en nieuw aan te leggen natuurgebieden. Het NNN heeft als doel om de achteruitgang van het areaal aan natuur en van de biodiversiteit te stoppen door een samenhangend netwerk van natuurgebieden te creëren. De provincies zijn verantwoordelijk om dit netwerk te realiseren. Na de herijking zal het NNN circa 20\% van het landoppervlak beslaan (circa 695.000 ha). Naast het NNN op het land zijn alle Rijkswateren, waaronder de Waddenzee, het IJsselmeer, de Zeeuwse delta en de Noordzee aangewezen als onderdeel van het NNN. De Natura 2000-gebieden liggen grotendeels binnen het NNN (op circa 27.000 hectare van vooral agrarische gebieden na).

\section{GDs en het NNN}

De GDs die van toepassing zijn op het NNN, zoals de GDs Natuur \& Gastvrijheid, richten zich vooral op het terrestrische deel. Het aquatische NNN is met de GDs Biodiversiteit Oosterschelde (GD074) en Visserij voor een schone zee (GD171) relatief ondervertegenwoordigd.

\section{GDs Natuur \& Gastvrijheid}

Het NNN is een aantrekkelijke omgeving om te recreëren. Veel gastvrijheidsbedrijven, zoals campings en bungalowparken, zijn dan ook gelegen in of nabij het NNN. Om concurrerend te blijven, moeten deze bedrijven blijven vernieuwen om tegemoet te komen aan de wensen van recreanten en toeristen. Wetten en regels, en de interpretatie daarvan, zorgen echter nogal eens voor vertraging of zelfs dat de benodigde ontwikkelingsruimte er niet komt. Dat geldt vooral voor gastvrijheidsbedrijven in of nabij kwetsbare natuur zoals het NNN. Om hierin een oplossing te vinden zijn de GDs Natuur en Gastvrijheid (GD037, 103, 104, 105, 106, 107, 138, 182) afgesloten. De Stichting Innovatie Recreatie en Ruimte (STIRR) is in al deze GDs een belangrijke partij. De STIRR ${ }^{8}$ heeft de ambitie om recreatie en toerisme (de gastvrijheidssector) tot een gewaardeerde partner te maken bij gebiedsontwikkeling.

\footnotetext{
${ }^{8}$ STIRR: www.recreatieenruimte.nl
} 
Groene groei is dan ook leidraad bij de GDs Natuur \& Gastvrijheid. Verbeterpunten zitten vooral bij het betrekken van kennis over biodiversiteit en SMART-formulering van doelen. Meer specifiek per indicator:

\section{Indicator: Kennisinstellingen biodiversiteit en andere GD-partijen}

De GD opereert volgens de zogenaamde urgentiedriehoek, waarbij op basis van ondernemersurgenties, overheidsurgenties en gebiedsurgenties wordt gezocht naar een win-winsituatie. TBOs en PGOs zijn officieel geen tekenpartij in de GDs. Wel zullen TBOs bij veel bedrijven actief zijn in het gebied rondom een recreatiebedrijf, waardoor ze hun kennis over inrichting en beheer van natuur kunnen inbrengen.

2. Indicator: Voortgang in het innovatieproces

Het doel was om via GDs vijf icoonprojecten te starten. Dat zijn er uiteindelijk zeven geworden, al zijn er ook twee voortijdig gestaakt, omdat de ondernemer afhaakte. Binnen de GDs is de zogenaamde urgentiedriehoek ontwikkeld waardoor procedures veel sneller worden doorlopen. De GDs leiden vanwege een verbeterd gastvrijheidsproduct tot versterking van de lokale/regionale economie. Ondernemers dragen ook financieel bij aan ontwikkeling, waarbij de bijdrage afhangt van de verwachtingen over extra omzet. Nieuwe cases zijn onderweg, ook na afronding van de GDs. Deze cases worden door de STIRR begeleid.

3. Indicator: Natuur en biodiversiteit als hoofddoel

De GDs dragen bij aan zes van de acht doelen uit de Rijksnatuurvisie en hebben een direct effect op biodiversiteit door natuurontwikkeling, -beheer en/of de aanleg van groen.

4. Indicator: SMART-formulering van doelen

In de GD-teksten gaat het vooral over inspanningsverplichtingen en enkele afrekenbare doelen. Bij Uitbreiding Camping Zeeburg (GD105) bijvoorbeeld gaat het om de "aanleg van een circa 1,5 ha groot kampeereiland, aansluitend op de provinciale ecologische verbindingszone Bovendiep, waarvan de oevers op een natuurlijke wijze worden ingericht en beheerd". Doelsoorten, minimale breedte van de oevers (oppervlak natuur), oeverprofiel e.d. worden niet genoemd, terwijl dat juist wel belangrijke aspecten zijn als het om de toekomstige natuurwaarden gaat.

5. Indicator: Potentie voor opschaling

De GDs hebben een voorbeeldfunctie en wat dat betreft zijn de kansen voor opschaling groot. De GDs betreffen reeds zeven pilots van gastvrijheidsondernemingen onder de noemer Natuur en Gastvrijheid, maar dat is slechts een fractie van de circa 2400 kampeerterreinen en 2400 vakantieparken en B\&B's in Nederland. Velen daarvan zijn eveneens gelegen in of nabij het NNN. Een natuurlijker inrichting van deze terreinen kan de natuurwaarden van het NNN versterken. Een toename in natuurkwaliteit, kan daarmee in potentie enig verlies aan natuuroppervlak (als gevolg van uitbreiding) compenseren.

Het feit dat wordt geïnvesteerd in mooie omgeving betaalt zich terug. De ondernemer krijgt een groener imago, heeft een goed verhaal en onderscheid zich daarmee van zijn concurrenten. Veelal kan men daardoor ook een hogere prijs vragen voor het recreatieve product (STIRR, Driebergen, 2016 persoonlijke mededeling).

\subsubsection{Natuur en biodiversiteit in het agrarisch gebied}

\section{Agrarisch gebied}

De landbouw is met circa 47\% (1,6 miljoen ha) van het landoppervlak (3,4 miljoen ha) de grootste grondgebruiker in Nederland. Het landbouwareaal bestaat voor 993.000 ha $(62 \%)$ uit grasland, 517.000 ha $(32 \%)$ uit akkerbouw, 87.000 ha $(>5 \%)$ uit open tuinbouw en 9.500 ha $(<1 \%)$ uit glastuinbouw (data 2014, CBS et al., 2015d).

In 2012 bedroeg het aandeel biologische landbouw in het totale Nederlandse landbouwareaal nog slechts 2,6 procent (CBS et al., 2015e). Het overgrote deel bestaat dus uit intensieve landbouw. De landbouwsector heeft daarmee de afgelopen decennia een desastreus effect gehad en heeft dat nog steeds op de biodiversiteit in Nederland (Berendse, 2016). De broedvogelpopulaties van het boerenland zijn sinds 1960 bijvoorbeeld met 75\% afgenomen. Soorten die vroeger algemeen waren, zoals de Veldleeuwerik (Alauda arvensis) en Patrijs (Perdix perdix) staan nu op de Nationale Rode Lijst na populatieafnames van respectievelijk 96\% en 93\% sinds 1960 (SOVON, 2012). 


\section{GDs en het agrarisch gebied}

Een beperkt aantal GDs richt zich op de biodiversiteit van het agrarisch gebied, zoals Producerend landschap (GD072), Duurzaamheid Doorgrond (GD108) en Samen ondernemen in landbouw en natuur (GD073). Bij laatstgenoemde gaat het erom dat Brabantse boeren en TBOs meer gaan samenwerken. Bijvoorbeeld dat boeren het beheer uitvoeren van natuurgrasland en natuurakkers. Het is opvallend dat veenweidegebieden niet of nauwelijks onderdeel uitmaken van de GDs Biodiversiteit. Dit ondanks de dramatische achteruitgang van weidevogelpopulaties en de internationale verantwoordelijkheid die Nederland hierbij heeft. Met name wat betreft de Grutto waarvan de broedpopulatie grotendeels van de Nederlandse veenweides afhankelijk is.

\section{GD Duurzaamheid Doorgrond}

De GD Duurzaamheid Doorgrond (GD 108) richt zich op de verduurzaming van akkerbouwbedrijven, op ecologisch, sociaal en economisch gebied, volgens de methode van de Stichting Veldleeuwerik. Participerende akkerbouwers schrijven aan de hand van tien indicatoren ieder jaar een duurzaamheidsplan voor hun bedrijf. Biodiversiteit is één van die indicatoren. De betreffende GD kan in potentie een groot effect hebben op de biodiversiteit van het agrarisch gebied. Het potentieel effect op natuur en biodiversiteit van de GD Duurzaamheid Doorgrond lijkt beloftevol. Verbeterpunten zitten er vooral bij het betrekken van kennis over biodiversiteit. Meer specifiek per indicator:

\section{Indicator: Kennisinstellingen biodiversiteit en andere GD-partijen}

Naast Stichting Veldleeuwerik is alleen de Rijksoverheid tekenpartij van de GD. Binnen Stichting Veldleeuwerik werken akkerbouwers aan verduurzaming van de voedselproductie, tezamen met toeleveranciers, afnemers en een geaccrediteerde duurzaamheidsadviseur. TBO's en/of PGO's zijn geen (vaste) partij binnen de Veldleeuwerik-systematiek. Kansen voor insecten, vogels e.d. worden daardoor mogelijk onderbenut, alsook de kansen die dit biedt voor de boer in de vorm van biologische bestuiving en plaagbestrijding.

2. Indicator: Voortgang in het innovatieproces

Binnen de GD is een certificering opgezet om kwaliteit bij opschaling te kunnen waarborgen. De GD kent een gestaag groeiend aantal participerende telers/akkerbouwers. Dus zit deze in de opschalingsfase. Minder input van mest- en gewasbeschermingsstoffen leidt tot kostenbesparing. Een biodiversere bodem lijkt beter bestand tegen extremen, zoals droogte en langdurige neerslagperiodes, waardoor de oogstopbrengst stabieler is. Duurzame(re) akkerbouw leidt ook tot een aantrekkelijker landschap voor recreatie.

3. Indicator: Natuur en biodiversiteit als hoofddoel

De GD draagt bij aan vijf van de acht doelen uit de Rijksnatuurvisie alsook aan de Uitvoeringsagenda Natuurlijk Kapitaal. De GD leidt tot een duurzamere meer natuurinclusieve vorm van akkerbouw, zoals door de aanleg van bloemrijke akkerranden.

4. Indicator: SMART-formulering van doelen

De doelen zijn grotendeels SMART geformuleerd, zoals 500 telers en 100 aangesloten bedrijven in 2013 en 1000 telers in 2014. Er is zeker sprake van opschaling, maar met bijna 400 telers en 60 aangesloten bedrijven eind 2016, lijken de SMART-doelen achteraf te ambitieus gesteld.

5. Indicator: Potentie voor opschaling

In Nederland zijn circa 12.000 akkerbouwbedrijven en ruim 90\% van het akkerbouwareaal wordt nog niet bewerkt volgens de Veldleeuwerik-methode. Ook is met Brussel overeengekomen dat akkerbouwers met een Veldleeuwerik-certificaat meer keuzemogelijkheid hebben bij de verplichting om $5 \%$ van hun areaal in te vullen als ecologisch aandachtsgebied. De kansen voor opschaling worden daarom groot geacht.

\subsubsection{Natuur en biodiversiteit in het stedelijk gebied}

\section{Stedelijk gebied}

Het bebouwde oppervlak in Nederland, bedraagt circa 10\% (356.000 ha) van het totale landoppervlak (3,4 miljoen ha). Het betreft hier merendeels stedelijk gebied. Terwijl het bebouwde landoppervlak verder toeneemt, gaat de biodiversiteit van het stedelijk gebied achteruit. Tussen 1990 en 2014 bijvoorbeeld, gingen broedvogels en dagvlinders in de bebouwde kom met gemiddeld $30 \%$ in populatie-omvang achteruit. Illustratief is de vermelding van de Huismus (Passer domesticus) op de Nationale Rode Lijst. Vlinderpopulaties gingen gedurende de hele periode in omvang achteruit, terwijl bij vogels de situatie de laatste tien jaar stabiel bleef (CBS, 2015f). 
Een belangrijke oorzaak voor de achteruitgang is de afname van het groene oppervlak. Door voortschrijdende verdichting van de bebouwing verdwijnen braakliggende landjes met onkruid en ruigtes. Tuinbezitters vervangen steeds vaker het groen voor tegels en nestplaatsen voor vogels gaan verloren als gevolg van renovatie, isolatie en sneldakpannen. Daarnaast laat ook het gangbare beheer te wensen over. Gazons en grasbermen worden vaak gemaaid en het maaisel gehakseld zodat de bodem verrijkt. Hierdoor verarmt de vegetatie waardoor voedselbronnen voor vogels (zaden, insecten) en vlinders (nectar- en waardplanten) afnemen.

\section{GDs en het stedelijk gebied}

Verschillende GDs proberen de afname van natuurwaarden in het stedelijk gebied te keren. Levende duurzame buitenruimtes (GD148) richt zich op de bewustwording voor het gebruik van duurzame materialen en inheemse beplanting voor tuinen, parken en overig groen. De GDs Groene daken (GD167, 200) beogen om daken van teer en grind te beplanten met inheemse begroeiing, wat onder andere ten goede moet komen aan insecten en ook verschillende ecosysteemdiensten zal leveren (zoals wateropslag, isolatie in de winter en verkoeling in de zomer). Met Tijdelijke natuur (GD066) kan zich op terreinen met een andere bestemming dan natuur, tijdelijk waardevolle natuur ontwikkelen, terwijl de grondeigenaar de garantie heeft dat de uiteindelijke bestemming niet in gevaar komt. Dit komt vooral ten goede aan zogenaamde pioniersoorten. Met 1000 hectare nieuwe stedelijke natuur (GD193) vervolgens willen 40 gemeenten de biodiversiteit verder bevorderen door natuurlijk inheems groen naar de stad te halen in parken, plantsoenen en braakliggende terreinen.

\section{GDs en de Vlinderstichting}

Bij alle hierboven genoemde GDs in het stedelijk gebied is de Vlinderstichting betrokken. Zij ziet GDs als een goede manier om haar ambities te verwezenlijken, dat wil zeggen het versterken van het Natuurnetwerk Nederland door de natuur daarbuiten te ontwikkelen. Het potentiële effect op natuur en biodiversiteit van de GDs waar de Vlinderstichting bij betrokken is, lijkt over het algemeen beloftevol, al zijn er een paar GDs die pas in 2016 zijn gestart zodat daar nog weinig resultaten van zijn. Meer specifiek per indicator:

\section{Indicator: Kennisinstellingen biodiversiteit en andere GD-partijen}

De hierboven genoemde vijf GDs kennen gemiddeld elf ondertekende partijen, waarvan de Vlinderstichting er één is (behalve bij GD148, waarbij ze wel betrokken is maar niet als tekenpartij). De Vlinderstichting voert ook onderzoek uit om na te gaan hoe de biodiversiteitwaarde kan worden vergroot, bijvoorbeeld voor het maaibeheer en de inrichting van groene daken.

2. Indicator: Voortgang in het innovatieproces

Sommige van de genoemde GDs zijn pas in 2016 gestart, anderen lopen al langer zoals de GD Tijdelijke Natuur. Voor deze GD heeft aanpassing van de Ff-wet plaatsgevonden, is inmiddels 3000 ha tijdelijke natuur ingericht en is een stichting opgezet voor de periode na de GD. Ook andere GDs zoals Groene daken zijn beloftevol met vijf potentiële economische (en maatschappelijke) verdienmodellen.

3. Indicator: Natuur en biodiversiteit als hoofddoel

De deals dragen bij aan vier tot vijf van de acht doelen uit de Rijksnatuurvisie en er vindt ook natuurontwikkeling plaats.

4. Indicator: SMART-formulering van doelen

De doelen zijn deels SMART geformuleerd, bijvoorbeeld daar waar het aantal pilotprojecten betreft voor tijdelijke natuur of groene daken.

5. Indicator: Potentie voor opschaling

De kansen voor opschaling bij de betreffende GDs zijn groot gezien de circa 35.000 ha (bouw)grond aangekocht door overheden en projectontwikkelaars, het grote oppervlak aan daken dat potentieel geschikt is als groen dak en het feit dat er naast de 40 gemeenten die deelnemen aan de GD 1000 hectare nieuwe stedelijke natuur, er nog 310 gemeenten zijn die dat nog niet doen. 


\subsubsection{Ecologische verbindingen tussen natuurlijke, agrarische en stedelijke gebieden}

\section{Ecologische verbindingen}

Nederland beschikt over een dicht netwerk aan infrastructuur, zoals $139.000 \mathrm{~km}$ aan wegen waarvan $20.000 \mathrm{~km}$ rijks- en provinciale wegen, $3000 \mathrm{~km}$ spoorwegen (CBS et al., 2015g) en $1345 \mathrm{~km}$ dijken (Henkens et al., 2014). Langs deze wegen en spoorwegen, onder hoogspanningsmasten en bij watergangen en dijken liggen veel terreinen die ecologisch veel potentie hebben. Natuur langs infrastructuur is in potentie bij uitstek geschikt om de biodiversiteit van het Natuurnetwerk Nederland, het agrarisch gebied en het stedelijk gebied beter met elkaar te verbinden.

\section{GDs en ecologische verbindingen}

Verschillende GDs spelen hier op in, zoals Blauwzaam Lint (GD102) waarbij langs infrastructuur en op braakliggende gronden in de Alblasserwaard en Vijfherenlanden, natuurlijke en bloemrijke vegetaties worden aangelegd. De pas in 2016 gestarte GD Infranatuur (GD169) beoogt feitelijk hetzelfde, maar dan op een groter schaalniveau.

\section{GDs en de Vlinderstichting}

Bij beide hierboven genoemde GDs is de Vlinderstichting betrokken, aangezien zij deze zien als een goede manier om hun ambities te verwezenlijken, dat wil zeggen het versterken van het Natuurnetwerk Nederland door de natuur daarbuiten te ontwikkelen. Deze kan dan ondersteunend zijn aan natuur binnen het Netwerk. Het potentiële effect op natuur en biodiversiteit van de betreffende GDs lijkt over het algemeen beloftevol al is de GD Infranatuur pas in 2016 gestart, waardoor de resultaten nog beperkt zijn. Meer specifiek per indicator:

\section{Indicator: Kennisinstellingen biodiversiteit en andere GD-partijen}

Blauwzaam Lint kent vier ondertekende partijen, Infranatuur maar liefst 20. De Vlinderstichting is bij Infranatuur officieel tekenpartij, bij Blauwzaam Lint alleen participerend. De Vlinderstichting brengt kennis in over het maximaliseren/optimaliseren van de biodiversiteitwaarde, bijvoorbeeld voor de vegetatiesamenstelling en het maaibeheer. Daarmee kunnen kansen voor kritische (vlinder)soorten, die hoge eisen stellen aan hun leefomgeving, zo goed mogelijk worden benut.

2. Indicator: Voortgang in het innovatieproces

Blauwzaam Lint wordt reeds opgeschaald naar andere regio's. Binnen de GD Infranatuur (gestart eind 2016) wordt er onder andere mee geëxperimenteerd om ecologische vraagstukken reeds in de aanbesteding van bijvoorbeeld een snelwegverbreding mee te geven. Dergelijke GDs leiden tot een verbetering van natuur en landschap en een prettiger woon- en werkklimaat wat gunstig kan zijn voor de lokale/regionale economie. De (onderhouds-)kosten en baten dienen verder inzichtelijk te worden gemaakt, om na te gaan wat de economische en maatschappelijk verdienmodellen zijn.

3. Indicator: Natuur en biodiversiteit als hoofddoel

De GDs dragen bij aan vijf tot zeven doelen uit de Rijksnatuurvisie en richten zich op natuurontwikkeling buiten het NNN. Daarmee kan de natuur binnen het NNN worden versterkt.

4. Indicator: SMART-formulering van doelen

De doelen zijn deels SMART geformuleerd, bijvoorbeeld daar waar het concrete acties en pilotprojecten betreft om natuurwaarden te ontwikkelen door partijen zoals Vitens, Tennet, Heijmans, Waterschappen enz.

5. Indicator: Potentie voor opschaling

De kansen voor opschaling zijn groot gezien de grote lengte aan infrastructuur in Nederland hetzij wegen, spoorwegen, waterwegen, hoogspanningsleidingen enz.

\subsubsection{Natuur en biodiversiteit internationaal}

\section{Effect Nederland op internationale biodiversiteit}

Nederland is een klein land met een hoge bevolkingsdichtheid. Voor onze consumptie zijn we grotendeels van het buitenland afhankelijk, met bijkomende effecten op de biodiversiteit in die landen. De ecologische voetafdruk van Nederland is circa drie keer groter dan het Nederlandse landoppervlak (Wilting et al., 2015). Van het land dat in gebruik is voor deze Nederlandse voetafdruk ligt circa $15 \%$ in Nederland zelf, circa $50 \%$ in de andere OESO-landen, circa $25 \%$ in de transitielanden (Brazilië, Rusland, India, Indonesië, China en Zuid-Afrika, de zogenoemde BRIICS-landen) en circa $10 \%$ in de 
rest van de wereld, waaronder het Midden-Oosten en ontwikkelingslanden (Van Oorschot et al., 2012). Gezien de ecologische voetafdruk van Nederland in het buitenland kan er in potentie veel worden bereikt indien we ons consumptiepatroon verduurzamen.

\section{GDs en internationale biodiversiteit}

De Nederlandse overheid heeft de ambitie om internationale handelsketens te verduurzamen. Vooral GDs zoals Bevorderen Duurzaam Bosbeheer (GD150) en ook wel Duurzaam Toerisme (GD175) passen binnen deze ambitie. Bevorderen Duurzaam Bosbeheer (GD150) gaat over het bevorderen van duurzaam bosbeheer, wereldwijd. Het vergroten van de vraag naar duurzaam hout is daarvoor een belangrijke impuls. De GD wil de bekendheid en afzet van aantoonbaar duurzaam geproduceerd hout op de Nederlandse markt vergroten, met als doel om het aandeel hout uit duurzaam beheerde bossen op de Nederlandse markt te vergroten. Duurzaam Toerisme (GD175) gaat over het bevorderen van duurzaam toerisme middels het ontwikkelen van een door alle partijen gedragen visie. Om dat te bereiken werken zij samen, wisselen ze kennis en ervaring uit en ondernemen ze acties. Daarnaast zetten partijen in op het ontwikkelen van methodes, processen en middelen om de duurzaamheid en het verduurzamen van bestemmingen te bevorderen.

Het is opvallend dat de meeste andere GDs Biodiversiteit vooral zijn gericht op Nederland. En dan vooral het Europese deel want de activiteiten in Caribisch Nederland zijn (vooralsnog) beperkt. GDs voor duurzame handel zijn er naast de houtketen ook voor de koffieketen (EL\&I en KNVKT, 2012; overigens geen GD Biodiversiteit), maar voor andere prioritaire ketens (bijv. vis, palmolie, soja en cacao) zijn er geen GDs, maar wel andere initiatieven die grotendeels hetzelfde beogen.

\section{GD Bevorderen Duurzaam Bosbeheer}

Twee derde van alle biodiversiteit op het land komt voor in bossen, met name tropische bossen, en meer dan 1 miljard mensen zijn voor hun levensonderhoud afhankelijk van bos. Circa $90 \%$ van het hout dat in Nederland geconsumeerd wordt komt uit het buitenland. De Nederlandse impact is dan ook mondiaal want het hout wordt uit 48 verschillende landen geïmporteerd, variërend van de tropen tot de poolcirkel. De Koninklijke Vereniging Van Nederlandse Houtondernemingen (VVNH) is de overkoepelende brancheorganisatie van 205 groothandelsbedrijven in hout en initiator van de GD Bevorderen Duurzaam Bosbeheer (van Oorschot et al., 2015).

Het potentiële effect op natuur en biodiversiteit van de GD Bevorderen Duurzaam Bosbeheer lijkt beloftevol. Verbeterpunten zitten er vooral bij de SMART-formulering van doelstellingen en het oplossen van knelpunten. Meer specifiek per indicator:

\section{Indicator: Kennisinstellingen biodiversiteit en andere GD-partijen}

De GD heeft 28 ondertekenende partijen (incl. twee ministeries) en brengt de belangrijkste partijen in de keten samen. De deal heeft geen betrekking op de aanleg en het beheer van natuur waardoor TBO's en PGO's hier niet van toepassing zijn. Wel wordt via een partij zoals Tropenbos International veel kennis ingebracht, en de aanwezigheid van deze partij helpt ook met de acceptatie bij andere ondertekenaars van verdere stappen partners vanwege hun onafhankelijke en wetenschappelijke positie.

2. Indicator: Voortgang in het innovatieproces

Binnen de GD zijn pilots uitgevoerd met bedrijven om een certificatieregeling in de praktijk te verkennen/ realiseren ( $\operatorname{stap} 2$ ). De acties zijn te schetsen als kennisverspreiding over het certificeringssysteem bij branches die daar nog niet bekend mee zijn, en dat is een voorwaarde voor opschaling. Er zijn echter nog de nodige aanbevelingen om tot een GD 2.0 te komen (Doornebosch et al., 2015). Inmiddels is de opzet van een vervolg grotendeels uitgewerkt in een convenant voor internationaal MVO.

3. Indicator: Natuur en biodiversiteit als hoofddoel

De deal betreft de concrete uitwerking van het actiepunt 'Meer hout uit duurzaam beheerde bossen op de Nederlandse markt' van de Uitvoeringsagenda Natuurlijk Kapitaal. Gecertificeerd hout komt uit duurzaam beheerde bossen en heeft daarmee in potentie een groot effect op de biodiversiteit door de bijdrage aan het vermijden van verder ontbossing (door het waarde geven aan bossen). 


\section{Indicator: SMART-formulering van doelen}

De doelen van de GD betroffen vooral een inspanningsverplichting voor bewustwording en communicatie in verschillende branches van de houtsector en zijn daarmee niet SMART geformuleerd. Het convenant dat kan worden beschouwd als een vervolg heeft wel SMART geformuleerde doelen.

5. Indicator: Potentie voor opschaling

De kansen voor opschaling zijn groot gezien het grote aantal actoren en bedrijfstakken in de houtindustrie dat nog niet met het kopen en verkopen van gecertificeerd hout actief is, terwijl de houthandel dit hout al wel kan aanbieden. Daarnaast blijkt er in het buitenland belangstelling voor de Nederlandse GD-aanpak.

Groot knelpunt voor marktacceptatie is echter het prijsverschil van circa $30 \%$ tussen het ongecertificeerde hout en het duurdere gecertificeerde hout, en dat geldt met name bij tropisch hout. Binnen de GD zijn hiervoor wel oplossingen aangedragen, maar deze zijn (nog) niet geaccepteerd binnen het Ministerie van Financiën en de EU. Om gecertificeerd hout grotere kansen op de markt te geven helpt het ook om ongewenste stromen van de markt weren. Dan kan onder de handelsregels als het om praktijken gaat die als illegaal worden beoordeeld in de landen van herkomst. Inzet van de Nederlandse overheid is daarom om eerst een Level playing field aan te brengen, via EU-regulering voor illegale stromen (via het FLEGT-beleid en de EU Timber Regulation) .

\subsection{Samenvatting}

Uit hoofdstuk 2 bleek dat de GD-doelen in meer of mindere mate aansluiten op alle beleidsdoelen, zoals verwoord in de Rijksnatuurvisie 2014 en de Uitvoeringsagenda Natuurlijk Kapitaal. Wat dat betekent voor het concrete effect van deze GDs op natuur en biodiversiteit wordt niet gemeten. De huidige monitoring door de Rijksdienst voor Ondernemend Nederland (RVO) is vooral gericht op de procesgang. Om toch het potentieel positieve effect op natuur en biodiversiteit inzichtelijk te maken, zijn een vijftal indicatoren opgesteld; 1) Betrokkenheid kennisinstellingen natuur en biodiversiteit en andere GD-partijen, 2) Fase in het innovatieproces, 3) Natuur en biodiversiteit als hoofddoel, 4) SMART-formulering van doelen, en 5) Potentie voor opschaling.

Uit analyse van de GDs op deze indicatoren kunnen de volgende conclusies worden getrokken:

- Indicator 1: Betrokkenheid kennisinstellingen natuur en biodiversiteit en andere GD-partijen Een GD heeft waarschijnlijk de meeste kans van slagen indien de belangrijkste stakeholders met elkaar gaan samenwerken. Voor het effect op natuur en biodiversiteit van een GD is het van groot belang dat er ook voldoende kennis hierover wordt betrokken. Als een GD bijvoorbeeld leidt tot de aanleg van hectares groen (natuurkwantiteit) dan is de uiteindelijke natuur- of biodiversiteitwaarde sterk afhankelijk van de wijze waarop het gebied wordt ingericht (onder andere situering van ecologische corridors in het landschap) en hoe het wordt beheerd (natuurkwaliteit). De kennis hiervoor is vooral aanwezig bij terreinbeherende organisaties (TBO's) en PGO's. Toch zijn deze organisaties betrokken bij niet meer dan ongeveer de helft van de GDs, waarbij groen wordt aangelegd of beheerd. De Vlinderstichting is bovendien de enige PGO die bij (zeven) GDs betrokken is. De kennis en kunde van de betrokken partijen in de overige GDs is onduidelijk, maar de kansen voor kwalitatief hoogwaardige natuurwaarden worden waarschijnlijk onderbenut.

\section{- Indicator 2: Fase in het innovatieproces}

De GDs kunnen bijdragen aan de voortgang in het innovatieproces door bijvoorbeeld stappen te zetten voor de organisatiestructuur van GD-partijen, het implementeren van pilots en het oplossen van knelpunten om zodoende te kunnen opschalen. In dit innovatieproces worden drie stappen onderscheiden: 1) kwartiermaken, 2) demonstreren en 3) opschalen. GDs kunnen in alle drie de stappen worden afgesloten. In alle GDs worden door partijen acties ondernomen die kunnen worden gekenmerkt als 'kwartiermaken' (stap 1). Ruim een kwart van de afgeronde GDs is echter niet verder gekomen dan kwartiermaken (waarvan de helft bovendien niet of nauwelijks realiseerbaar is gebleken). Ruim de helft van de GDs blijkt ook tot stap 2 te zijn gekomen en bijna een kwart tot stap 3. Omdat circa een derde van de GDs nog in uitvoering is kunnen deze resultaten nog enigszins verschuiven. 


\section{- Indicator 3: Natuur en biodiversiteit als hoofddoel}

Voor twee derde van de GDs is natuur en biodiversiteit direct of indirect een hoofddoel. De overige GDs richten zich vooral op andere duurzaamheidsthema's zoals energie, afval, gezondheid en voedsel, waarbij natuur en biodiversiteit eerder een nevendoel is.

- Indicator 4: SMART formulering van doelen

Afrekenbare doelen vergroten de kans dat deze doelen ook worden bereikt. De doelen van een GD Biodiversiteit dienen daarom bij voorkeur SMART te zijn geformuleerd. Naar schatting de helft blijkt daaraan te voldoen. Dit komt vooral doordat de GD-aanpak is gericht op het stimuleren van dynamiek in de samenleving en niet zozeer op afrekenbare resultaten.

\section{- Indicator 5: Potentie voor opschaling}

Een GD moet idealiter een innovatie zijn die breed kan worden uitgerold over Nederland of daarbuiten. Sommige GDs zijn echter dermate uniek en/of locatie-gebonden dat de kansen voor opschaling beperkt zijn.

Een analyse op deze vijf indicatoren indiceert dat het potentiële effect op natuur en biodiversiteit bij iets minder dan de helft van de GDs beperkt lijkt en bij ruim de helft beloftevol. Beloftevolle GDs zijn actief binnen verschillende aandachtsvelden van natuur, zoals het Natuurnetwerk Nederland, het agrarisch gebied, het stedelijk gebied en ecologische verbindingen. Dit komt tegemoet aan het hoofddoel van de Rijksnatuurvisie, namelijk het realiseren van een veelzijdige natuur met een stevige basis.

Desalniettemin moet het effect van deze GDs op natuur en biodiversiteit niet worden overschat. Er zijn nog genoeg aandachtsvelden waaraan niet wordt bijgedragen. De GDs zijn bijvoorbeeld vooral gericht op het land. Grote wateren met de kenmerkende deltanatuur zijn nauwelijks onderwerp van GDs. De GDs in het agrarisch gebied zijn vooral gericht op akkerbouw. De unieke veenweiden met weidevogels, waarvoor Nederland een grote internationale verantwoordelijkheid heeft, vormen geen aandachtsveld binnen de GDs. Ook de natuur en biodiversiteit van het Caribisch deel van het Nederlands Koninkrijk komt nog nauwelijks voor binnen de GDs Biodiversiteit, terwijl hier toch belangrijke natuurwaarden liggen waarvoor Nederland internationale verantwoordelijkheid draagt. Ook ten aanzien van internationaal natuur- en biodiversiteitbeleid zijn er naast hout nog verschillende andere prioritaire handelsketen waar Nederland via GDs een bijdrage kan leveren in het bereiken van de beleidsdoelen. Dat hoeft overigens niet allemaal via GDs te gebeuren, het is zaak om de inzet van GDs af te zetten tegen andere instrumenten (complementariteit). 


\section{$4 \quad$ Green deals Biodiversiteit nader beschouwd}

\subsection{De meerwaarde van de GDs Biodiversiteit}

Het blijkt dat de ambities/doelen van de GDs Biodiversiteit in meer of mindere mate aansluiten op alle doelen van de Rijksnatuurvisie en de Uitvoeringsagenda Natuurlijk Kapitaal (hoofdstuk 2). De uiteindelijke effecten op natuur en biodiversiteit worden niet of nauwelijks gemonitord. Desalniettemin geeft een analyse op een aantal indicatoren aan dat de helft van de GDs kansrijk is om een wezenlijke bijdrage aan de beleidsdoelen voor natuur en biodiversiteit te kunnen leveren (hoofdstuk 3). De GDs zijn opgezet om innovatie en vergroening te bevorderen. Vraag blijft echter wat de meerwaarde van de GD-aanpak voor innovatie nu oplevert voor natuur en biodiversiteit, ook ten opzichte van andere instrumenten. Er zou top-down goed gekeken moeten worden naar de optimale beleidsmix per beleidsdoel; wat de meest effectieve en efficiënte aanpak per doel is en welke rol GDs Biodiversiteit daarbinnen kunnen innemen.

\subsubsection{Meerwaarde van de GD-aanpak}

Volgens de geïnterviewde GD-partijen (de Vlinderstichting, Stichting Innovatie Recreatie \& Ruimte (STIRR), Stichting Veldleeuwerik en de Koninklijke Vereniging van Nederlandse Houtondernemingen $(\mathrm{VVNH})$ ) heeft de GD-aanpak het innovatieproces duidelijk versneld. Iets wat zonder de GDs niet of nauwelijks mogelijk zou zijn geweest. Zo is de Vlinderstichting inmiddels bij acht afgeronde, lopende én (potentieel) toekomstige GDs betrokken. Ze beschouwt de GDs als een belangrijk middel om samen met marktpartijen haar ambitie te verwezenlijken, dat wil zeggen het versterken van het Natuurnetwerk Nederland (NNN), door de natuur buiten het NNN te ontwikkelen. De STIRR is bij zeven GDs Natuur \& Gastvrijheid betrokken, 'die de sector nieuw elan hebben gegeven'. De GDs hebben laten zien dat recreatieondernemingen ook in kwetsbare natuurgebieden kunnen innoveren en groeien. Via de zogenaamde 'urgentiedriehoek', die binnen de GD is ontwikkeld, blijken procedures veel sneller te kunnen worden doorlopen. Voor Stichting Veldleeuwerik bleek de GD deuren te hebben geopend in Den Haag en Brussel. De Veldleeuwerik-systematiek voor duurzame akkerbouw wordt nu erkend binnen het Europese Gemeenschappelijk Landbouwbeleid, wat een goede stimulans is voor de beoogde opschaling. Voor de VVNH bleek de GD hét instrument om de vele partijen in de houtketen op één lijn te krijgen in het gezamenlijk streven om duurzaam hout uiteindelijk mainstream te laten worden in Nederland. Er is veel gewerkt aan bewustwording en de GD heeft de verschillende partijen daarmee rijp gemaakt voor een concretere en SMART geformuleerde vervolgstap.

Samenvattend bleek de meerwaarde van de GD voor de geïnterviewden te liggen in de samenwerking tussen de vele partijen, het enthousiasme en de innovaties die daaruit voortkwamen. Een resultaat dat, in de perceptie van de betrokkenen, met de gebruikelijke instrumenten blijkbaar niet kon worden gerealiseerd.

\subsubsection{GD geeft invulling aan maatschappelijk verantwoord ondernemen}

Uit bovenstaande voorbeelden blijkt dat een innovatief economisch verdienmodel niet per definitie het ultieme einddoel is van een GD en ook is het geen absolute voorwaarde voor succes. Voor de Vlinderstichting is het bijvoorbeeld een investering met eigen middelen om in de vele GDs te kunnen participeren. Gastvrijheidondernemers investeren in een mooiere omgeving, waar uiteindelijk ook andere ondernemers kosteloos baat bij kunnen hebben. Duurzame akkerbouwers die werken volgens de Veldleeuwerik-systematiek ondernemen niet per definitie lucratiever dan hun collega's in de minder duurzame intensievere akkerbouw, maar worden op een andere manier gewaardeerd dan wel gecompenseerd. Gecertificeerd hout zou idealiter goedkoper moeten zijn dan het niet-gecertificeerde hout, omdat de maatschappelijke externaliteiten (externe effecten of kosten) van duurzame houtproductie kleiner zijn. De hogere prijs van gecertificeerd hout wordt nu door een deel van de markt geaccepteerd onder de noemer van maatschappelijk verantwoord ondernemen (MVO), en wordt 
ook gestimuleerd door het duurzaam aanbestedingsbeleid van de overheid (weg- en waterbouw). De GDs geven blijkbaar invulling aan het begrip 'maatschappelijk verantwoord ondernemen'. En zo zijn er door de geïnterviewden nog meer voorbeelden genoemd waarbij partijen zich enthousiast inzetten voor bijvoorbeeld een natuurlijker inrichting en beheer van bedrijventerreinen, wat ook weer het draagvlak vergroot voor een duurzamere bedrijfsstrategie.

Het blijkt al met al dat de GDs voor deze, en waarschijnlijk andere partijen, een aantal knelpunten hebben opgelost, kansen hebben gecreëerd en tot inspiratie hebben geleid wat zonder de GDs niet zou zijn gebeurd. In die zin blijkt duidelijk de meerwaarde van het instrument GDs.

\subsection{Aandachtspunten bij opzetten en monitoren GDs Biodiversiteit}

Het effect van GDs op natuur en biodiversiteit kan waarschijnlijk nog worden vergroot. Dat begint al bij het opzetten van de GD. Het gaat daarbij om aandachtspunten zoals de samenstelling van de GDpartijen, de formulering van GD-doelen en de monitoring van effecten.

\subsubsection{Samenstelling GD-partijen}

\section{Kennisorganisaties biodiversiteit}

In het natuur- en biodiversiteitbeleid gaat de discussie enerzijds over kwetsbare soorten en ecosystemen waarvoor Nederland een duidelijke beschermingstaak heeft, anderzijds gaat het om het beter betrekken van maatschappelijke partijen bij het behoud en duurzaam gebruik. Idealiter zou dit samen kunnen gaan. Bijdragen aan natuur en biodiversiteit is dan ook meer dan de aanleg van een lap groen of een bloemrijke akkerrand.

In de 'gouden driehoek' (Van Vliet en Beers, 2011) gaat het om de samenwerking tussen overheid, bedrijfsleven en kennisinstellingen. Het betrekken van specifieke kennis over natuur en biodiversiteit is echter geen voorwaarde geweest bij het afsluiten van de GDs. Slechts bij de helft van de GDs waarbij groen wordt aangelegd of beheerd, heeft een erkende kennisorganisatie op het gebied van natuur en biodiversiteit als officiële partij de GD ondertekend (bijv. Staatsbosbeheer of de Vlinderstichting). Het betrekken van meer kennis over natuur en biodiversiteit in de GDs zal de biodiversiteitwinst kunnen vergroten.

\section{Andere overheden}

GDs zijn deals met de Rijksoverheid. De verschillende hogere en lagere overheden hebben verschillende rollen in het natuur- en biodiversiteitbeleid dat steeds meer decentraal is opgezet. Zoals afgesproken in het Natuurakkoord (2011) is de Rijksoverheid verantwoordelijk voor de kaders en ambities van het natuur- en biodiversiteitbeleid. De provincies zijn verantwoordelijk voor invulling en uitvoering van het beleid, samen met de gemeenten. De verschillende overheden hebben een eigen rol. Het is belangrijk om die rollen specifieker te benoemen en de verschillende overheden (nog meer dan nu) als tekenpartij bij de GD te betrekken.

\subsubsection{Formulering GD-doelen}

De doelen van de GDs Biodiversiteit sluiten in meer of mindere mate aan op één of meer beleidsdoelen van de Rijksnatuurvisie en/of Uitvoeringsagenda. Deze GD-doelen zouden over het algemeen echter (veel) sterker kunnen aansluiten op de beleidsdoelen voor natuur en biodiversiteit, de genoemde synergie is niet steeds herkenbaar (zie ook §4.3). Wel opvallend is (Hoofdstuk 2) dat sommige doelen maar beperkt voorkomen, met name bij de Uitvoeringsagenda. In het selectieproces voor het toekennen van GDs zou dat een aandachtspunt kunnen zijn, eventueel via oproepen voor specifiekere doelen uit het natuur en biodiversiteitbeleid. Daarnaast kunnen de doelen meer SMART worden geformuleerd, zodat een GD méér is dan een inspanningsverplichting. SMART-doelen bevorderen waarschijnlijk de voortgang in het innovatieproces, waardoor het uiteindelijke effect op natuur en biodiversiteit groter is. 
Deze SMART-doelen zijn wel afhankelijk van de fase waarin het innovatieproces verkeert. Zo kunnen voor de fase van 'kwartiermaken' doelen worden gesteld over een onderbouwing van de effecten op natuur en biodiversiteit (bijvoorbeeld via onderzoek) en het ontwikkelen van nieuwe verdienmodellen. Voor de pilot/demonstratie fase kunnen doelen worden gesteld over het aantal pilots en het oplossen van knelpunten. Voor de opschalingsfase kunnen doelen worden gesteld over het aantal gerealiseerde hectares natuur binnen een bepaalde periode. Op dit moment komen SMART-afspraken beperkt voor, in ongeveer de helft van de deals.

\subsubsection{Monitoring effecten natuur en biodiversiteit}

Monitoring van effecten is van belang om vast te kunnen stellen of GD-doelen zijn behaald. Dat hoeft niet persé de monitoring van soorten te zijn. Bij natuurdoelen gaat het vooral om het scheppen van bepaalde (minimale) milieucondities (middels inrichting en beheer) die randvoorwaardelijk zijn voor de ontwikkeling van kwetsbare ecosystemen en/of soorten. Of deze ook daadwerkelijk gaan voorkomen is vaak een lange termijn proces, wat bovendien afhangt van externe factoren die buiten de invloedssfeer van de GD vallen. Afhankelijk van het stadium in het innovatieproces kunnen indicatoren worden vastgesteld, waarmee kan worden gemonitord of met de GD de beoogde randvoorwaarden worden geschapen. Voor de pilotfase en opschalingsfase kunnen dat bijvoorbeeld indicatoren zijn in relatie tot het gevoerde maaibeheer, zoals de frequentie en periode van maaien, het al of niet gefaseerd maaien, het gebruikte maaimiddel (machine) en maatregelen omtrent de afvoer van het maaisel.

\subsection{Kansen voor nieuwe GDs Biodiversiteit}

\subsubsection{Opschaling kansrijke GDs}

Bovenstaande maakt duidelijk dat er nog het nodige te winnen valt, ook al wordt er aan alle beleidsdoelen van de Rijksnatuurvisie en Uitvoeringsagenda NK een bijdrage geleverd. GDs met een goede voortgang in het innovatieproces zouden verder kunnen worden gestimuleerd met vervolgdeals, zodat een positieve 'Deal flow' ontstaat (Schultz et al., 2016). Zoals het geval was met de afgeronde zeven GDs Natuur \& Gastvrijheid als vervolg op de GD Natuurlijk Kapitaal (GD037) en de lopende GD Groene Daken fase 2 (GD200) als vervolg op de GD Groene Daken (GD167). Opvolgende initiatieven worden reeds ontwikkeld, al hoeft dat niet per se een GD te zijn. Zo werkt de VVNH met partners en het Ministerie van Buitenlandse Zaken momenteel aan een IMVO-convenant (Internationaal Maatschappelijk Verantwoord Ondernemen), als opvolging van de GD Bevorderen Duurzaam Bosbeheer (GD150). Dat is een voor de hand liggend kader, omdat de innovatie voor dit onderwerp (certificering) al bestaat en zich in de markt al heeft bewezen. Opschaling moet nu vooral plaatsvinden in een internationaal kader. Wel is nog de vraag of geconstateerde knelpunten voldoende zijn aangepakt.

\subsubsection{Meer sturing op biodiversiteitthema's en GD-partijen}

Naast vervolg-GDs kan ook worden gedacht aan nieuwe GDs op natuur en biodiversiteitthema's die nu niet of ondervertegenwoordigd zijn. De bottom-up benadering van GDs hoeft nog niet te betekenen dat de overheid daar geen sturende rol in kan hebben. In de Evaluatie GDs van Kwink-groep (Gooskens et al., 2016) werd reeds geadviseerd om de aanwas van nieuwe deals te stimuleren door te zoeken naar manieren om nieuwe partijen te bereiken. Een manier zou kunnen zijn om nieuwe biodiversiteitthema's en veldpartijen te combineren met bestaande al dan niet afgeronde GDs. Nieuwe veldpartijen kunnen hun voordeel doen met samenwerking met ervaren GD-partijen. Onderbelichte biodiversiteitthema's binnen de GDs zijn bijvoorbeeld: de biodiversiteit van de grote wateren, biodiversiteit weidevogels, duurzame handelsketens en biodiversiteit van Caraïbisch Nederland.

\section{Biodiversiteit grote wateren}

Slechts weinig GDs zijn gericht op de grote wateren (d.w.z. het Waddengebied, de Zuidwestelijke Delta, het IJsselmeergebied, de Noordzee, het kustgebied en het rivierengebied), terwijl Nederland hier een grote internationale verantwoordelijkheid heeft voor het behoud van biodiversiteit. Zo zijn al deze gebieden (deels) Natura 2000-gebied en hebben ze betrekking op internationale 
biodiversiteitverdragen zoals Ramsar, AEWA, CMS, ASCOBANS. In de toekomstvisie 'Natuurambitie Grote Wateren 2050-2100' (Min EZ., 2014b) worden kennisvragen geformuleerd zoals over de gewenste synergie tussen natuur en andere gebruiksfuncties zoals recreatie, landbouw, visserij en transport. Ook hier zouden GDs een antwoord kunnen bieden, zoals voor de verduurzaming van de visserij of bij de ontwikkeling van jachthavens via opschaling van de GDs Natuur \& Gastvrijheid. 'Vergroening' van de haven van Amsterdam (GD65 Biodiversiteit en Economie) kan daarbij ter inspiratie dienen.

\section{Biodiversiteit weidevogels}

De weinige GDs die zijn gericht op het agrarisch gebied hebben vooral betrekking op akkerbouw. De biodiversiteit van het weidegebied blijft vooralsnog sterk onderbelicht, terwijl die biodiversiteit sterk achteruitgaat en Nederland hier een grote internationale verantwoordelijkheid heeft, vooral voor onze nationale vogelsoort, de Grutto. In november 2016 is het plan van aanpak weidevogels gepresenteerd (Min. EZ, 2016b), waarna de Vogelbescherming een klacht heeft ingediend bij de Europese Commissie vanwege het ontbreken van concrete (SMART)-doelstellingen en het niet voldoen aan de doelstellingen van de Europese Vogelrichtlijn. Deze problematiek biedt kansen voor het ontwikkelen van een GD Weidevogels vergelijkbaar met de GD Duurzaamheid Doorgrond (GD108) van de Stichting Veldleeuwerik. Nieuwe GD-veldpartijen kunnen dan bijvoorbeeld Vogelbescherming Nederland en SOVON Vogelonderzoek Nederland zijn.

\section{Duurzame Handelsketens}

GDs voor duurzame handel zijn er voor de houtketen (GD Bevorderen Duurzaam Bosbeheer) en de koffieketen (EL\&I en KNVKT, 2012; overigens geen GD Biodiversiteit). Ook zijn er binnen de GD Biodiversiteit en Economie bedrijven die werken aan verduurzaming van (onderdelen van) de hout-, koffie- en cacao-keten. Ook andere prioritaire ketens zoals gevangen vis, gekweekte vis, palmolie en soja richten zich op verduurzaming (Van Oorschot et al., 2015), maar het instrument GDs is daarbij (nog) niet toegepast. Er zijn voor deze ketens wel initiatieven vanuit de betrokken branche opgezet, met een andere organisatie en vaak minder brede groep aan betrokkenen. De resultaten met opschaling zijn verschillend, voor palmolie is er veel voortgang geboekt en is het doel gehaald, bij soja was er wel voortgang maar is het doel voor 2020 vermoedelijk buiten beeld (PBL, 2016 - Balans van de Leefomgeving). Een GD kan hier wellicht tot nieuwe inspiratie en deelnemers leiden voor ketens waar nog niet sterk op in is gezet, of waar de sector commitments niet haalbaar zijn gebleken (zoals bij soja).

\section{Natuur en biodiversiteit van Caraïbisch Nederland}

Eén van de doelen in het Natuurbeleidsplan Caribisch Nederland 2013-2017 (Min EZ, 2013) betreft: "Richtlijnen en initiatieven ontwikkelen voor innovatie op het gebied van duurzame ontwikkeling en duurzaam leven met betrekking tot Caribisch Nederland met een positief effect voor natuur". Dit doel heeft veel raakvlakken met de GDs Biodiversiteit. Toch is momenteel geen enkele GD specifiek gericht op de rijke biodiversiteit van het Caribisch deel van het Koninkrijk, terwijl Nederland daar een grote internationale verantwoordelijkheid heeft. Wel is er de GD Duurzaam Toerisme (GD175) met als doel om Nederlandse toeristische bestemmingen, waaronder op de Caraïben, wereldwijd te ondersteunen bij het verduurzamingsproces en consumenten ook te informeren over de kwaliteit en duurzaamheid van deze vakantiebestemmingen. In dat kader zijn er in 2016 zogenaamde Green Destination Assessments uitgevoerd op Bonaire, Saba en St. Eustatius en zijn er QualityCoast Awards uitgereikt (goud, zilver, brons) die de mate van duurzaamheid aangeven, als ook verbeterpunten.

De verwachte ontwikkeling van de toeristische sector en de kwetsbaarheid en beperkte omvang van de Caraïbische natuur, maakt het noodzakelijk dat verschillende doelen gezamenlijk worden opgepakt. De groei van de toeristische sector mag met andere woorden niet leiden tot het 'slachten van de kip met de gouden eieren'. Dat toeristisch-economische groei en natuurontwikkeling elkaar niet hoeven te bijten is bijvoorbeeld aangetoond binnen de GD Natuur \& Gastvrijheid. Het integreren van een aantal belangrijke natuurwaarden binnen gastvrijheidsbedrijven is ook op de Caraïben goed mogelijk. Natuurlijk aangelegde inheemse bloem- en vruchtrijke tuinen kunnen bijvoorbeeld leefgebied vormen voor veel inheemse soorten vlinders en vogels, zoals kolibries en de kwetsbare Geelvleugel Amazone (Amazona barbadenis) op Bonaire en reptielen, zoals de bedreigde Antillenleguaan (Iguana delicatissima) op St. Eustatius. Toeristen zullen een dergelijk terrein over het algemeen bovendien positief kunnen waarderen. 


\subsubsection{Positie Green Deals in instrumentenmix}

De meeste onderzochte GDs hebben een bijdrage geleverd aan groene innovatie, maar de manier waarop is divers. Een groot deel van de acties die partijen in de onderzochte GDs uitvoeren, bevindt zich in de prille innovatie-fase van kwartier maken. Bij diverse deals maken partijen al de stap naar het demonstreren van innovaties en een geringer deel van de onderzochte GDs draagt aanwijsbaar bij aan opschaling. Met de GDs heeft de overheid dus ruimte gegeven aan vernieuwing vanuit de maatschappij.

Individuele GDs dragen meestal bij aan een klein deel van het innovatieproces. Dat is niet per se een probleem of tekortkoming, zolang er maar een 'flow' qua groene innovatie op gang komt die de verschillende fasen van innovatie bestrijkt. Daar kun je GDs voor inzetten, zoals eerder werd voorgesteld (Schulze et al., 2016), maar dat is niet per se noodzakelijk. Voor het bereiken van 'flow' is het wellicht juist beter om andere instrumenten in te zetten. Het is daarom van belang dat de overheid de inzet van het instrument GDs voor bepaalde beleidsdoelen bekijkt vanuit een overall blik op doelen en beschikbare instrumenten. Ook kan dan worden geconstateerd voor welke onderwerpen meer aandacht voor maatschappelijke inbreng wenselijk is. Het is dus belangrijk hier, bij het aflopen van elke deal opnieuw, aandacht voor te blijven houden.

\subsection{Samenvatting}

Via GDs kunnen er innovatieprocessen gaan lopen die via de gebruikelijke beleidsinstrumenten blijkbaar niet of onvoldoende tot ontwikkeling komen. De meerwaarde van GDs lijkt te liggen in de bottom-up benadering en inspirerende samenwerking tussen GD-partijen uit verschillende sectoren. Dat kan leiden tot een creatieve oplossing van 'oude' knelpunten, het creëren van nieuwe kansen en uiteindelijk opschaling van de innovatie. Het gaat daarbij niet alleen om het streven naar financiële verdienmodellen. Ook het geven van invulling aan het begrip 'maatschappelijk verantwoord ondernemen' blijkt een belangrijke drijfveer. Een dergelijk proces vindt bij verschillende GDs plaats, maar (uiteraard) niet bij allemaal. De GDs leiden tot aantoonbaar meer groen, maar de potenties voor biodiversiteit worden waarschijnlijk nog onderbenut. Verbeterpunten liggen er onder andere bij het opzetten en monitoren van GDs. Daarnaast liggen er kansen op beleidsterreinen voor biodiversiteit die nu nog ondervertegenwoordigd zijn.

\section{Opzetten en monitoren van GDs Biodiversiteit}

Bij de GDs Biodiversiteit gaat het niet alleen om meer hectares groen (kwantiteit), maar vooral ook om meer biodiversiteit (kwaliteit). Het gaat niet alleen om algemene soorten, maar vooral ook om zeldzamere soorten. Dat vraagt om GD-partijen met praktische kennis over natuurbeheer en inrichting. Echter, bij slechts ongeveer de helft van de GDs waarbij groen wordt aangelegd of beheerd, zijn dergelijke kennisinstellingen officieel tekenpartij. Daarnaast is het van belang om bij de samenstelling van de GD-partijen goed te kijken naar de rol van de verschillende lokale en provinciale overheden in het natuurbeleid en deze overheden (nog meer dan nu) als tekenpartij op te nemen.

De doelen van de GDs Biodiversiteit sluiten in meer of mindere mate aan op één of meer beleidsdoelen maar dit zou nog veel sterker kunnen. In het selectieproces voor het toekennen van GDs zou dat een aandachtspunt kunnen zijn, eventueel via oproepen voor specifiekere doelen uit het natuuren biodiversiteitbeleid. Daarnaast dienen de doelen veel meer SMART te worden geformuleerd, zodat een GD méér is dan een inspanningsverplichting en het effect op natuur en biodiversiteit uiteindelijk groter is.

Monitoring van de effecten op biodiversiteit, of afgeleide indicatoren hiervan, is vervolgens van belang om na te gaan in hoeverre de GD-doelen zijn behaald, maar ook om te analyseren waar er nog verbeterpunten zijn. 


\section{Kansen voor nieuwe GDs Biodiversiteit}

Kansen voor nieuwe GDs Biodiversiteit liggen er enerzijds bij de opschaling van bestaande kansrijke GDs. Anderzijds kan sturing op natuur- en biodiversiteitthema's die nu nog ondervertegenwoordigd zijn, veel biodiversiteitwinst opleveren. Zo kan opschaling van de binnen de GDs Natuur \& Gastvrijheid ontwikkelde 'urgentiedriehoek' naar Caribisch Nederland, een win-win betekenen voor zowel biodiversiteit als de noodzakelijk geachte toeristisch-economisch ontwikkeling van de eilanden. Iets vergelijkbaars geldt waarschijnlijk voor de ontwikkeling van jachthavens langs de grote wateren in Nederland. Voor de biodiversiteit van deze wateren heeft Nederland een grote internationale verantwoordelijkheid, maar binnen de GDs Biodiversiteit komen ze nauwelijks voor. Hetzelfde geldt voor weidevogels, waarvan de populaties al jaren achteruit hollen. Een GD-aanpak zoals is opgezet voor akkerbouw, zou een belangrijke bijdrage kunnen leveren voor het behoud van deze soortgroep.

Omdat Nederland een belangrijk handelsland is, liggen er verschillende kansen om biodiversiteit ook internationaal via GDs te stimuleren. Daarbij kan men denken aan vertaling van de GD-aanpak voor de houthandel, naar andere prioritaire handelsketens zoals vis, palmolie, soja en cacao.

\section{GDs binnen de beleidsmix}

Meer in het algemeen zou goed gekeken moeten worden naar de optimale beleidsmix per beleidsdoel biodiversiteit. Wat is de meest efficiënte aanpak per doel, en welke rol kunnen GDs daarbinnen innemen? Een dergelijke top-down blik vraagt om meer regie op beleidsdoelen, en wat er met GDs bereikt kan worden. 


\section{Literatuur}

Berendse, Frank (2016). Wilde Apen. KNNV Uitgeverij. 96 p.

CBS, PBL, Wageningen UR (2015a). Flora van wegbermen 1999-2014 (indicator 1433, versie 04,25 november 2015 ). www.compendiumvoordeleefomgeving.nl. CBS, Den Haag; Planbureau voor de Leefomgeving, Den Haag/Bilthoven en Wageningen UR, Wageningen.

CBS, PBL, Wageningen UR (2015b). Infrastructuur, 2015 (indicator 2096, versie 06 , 13 oktober 2015). www.compendiumvoordeleefomgeving.nl. CBS, Den Haag; Planbureau voor de Leefomgeving, Den Haag/Bilthoven en Wageningen UR, Wageningen.

CBS, PBL, Wageningen UR (2015c). Trend fauna stad, 1990-2014 (indicator 1585, versie 01 , 29 oktober 2015 ). www.compendiumvoordeleefomgeving.nl. CBS, Den Haag; Planbureau voor de Leefomgeving, Den Haag/Bilthoven en Wageningen UR, Wageningen.

CBS, PBL, Wageningen UR (2015d). Land- en tuinbouw: ruimtelijke spreiding, grondgebruik en aantal bedrijven, 1980-2014 (indicator 2119, versie 06 , 30 juli 2015 ).

www.compendiumvoordeleefomgeving.nl. CBS, Den Haag; Planbureau voor de Leefomgeving, Den Haag/Bilthoven en Wageningen UR, Wageningen.

CBS, PBL, Wageningen UR (2015e). Biologische landbouw: aantal bedrijven en areaal, 1998-2014 (indicator 0011, versie 14, 21 mei 2015 ). www.compendiumvoordeleefomgeving.nl. CBS, Den Haag; Planbureau voor de Leefomgeving, Den Haag/Bilthoven en Wageningen UR, Wageningen.

CBS, PBL, Wageningen UR (2015f). Trend fauna stad, 1990-2014 (indicator 1585, versie 01 , 29 oktober 2015). www.compendiumvoordeleefomgeving.nl. CBS, Den Haag; Planbureau voor de Leefomgeving, Den Haag/Bilthoven en Wageningen UR, Wageningen.

CBS, PBL, Wageningen UR. (2015g). Infrastructuur, 2015 (indicator 2096, versie 06 , 13 oktober 2015). www.compendiumvoordeleefomgeving.nl. CBS, Den Haag; Planbureau voor de Leefomgeving, Den Haag/Bilthoven en Wageningen UR, Wageningen.

CBS, PBL, Wageningen UR (2009). Oppervlaktewater in Nederland (indicator 1401, versie 01,20 januari 2009 ). www.compendiumvoordeleefomgeving.nl. CBS, Den Haag; Planbureau voor de Leefomgeving, Den Haag/Bilthoven en Wageningen UR, Wageningen.

De Geeter, Sandra de, Miriam van Gool, Hans van de Veen en Erik van Zadelhof (eds) (2016). Natuurlijke Kapitaal. Brochure uitgegeven door Platform BEE, Ministerie van EZ, VNO-NCW en IUCN Nederlands Committee. 36 p.

Doornebosch, Berdi, Arjon Kalter en Ronald Hiel (2015). Impact studie. Green Deal Bevorderen Duurzaam Bosbeheer. Schuttelaar \& Partners B.V.: 44 p.

EL\&I en KNVKT (2012). Green Deal Driekwart Duurzame Koffie in Nederland in 2015, Den Haag: Ministerie van EL\&I.

Ganzevles, Jurgen, José Potting en Aldert Hanemaaijer (2016). Evaluatie Green Deals Circulaire Economie. Achtergrondstudie. Planbureau voor de :Leefomgeving, Den Haag. 65 p.

Gooskens, B. J. F., van Mil, B. P. A. en P. Modderman (2016). Evaluatie Green Deals. Eindrapport. Kwinkgroep. 93p.

Green Deal Board (2016). Verzilveren perspectief op groene groei. Voortzetting, aanscherping en opschaling Green Deal aanpak. 5 p.

Hamer, Astrid, Monique Mooren, Wouter Siemers, Dick Both \& Kees Kwant (2016). Monitoring Biobased Economy in Nederland 2015 (samenvatting). Rijksdienst voor Ondernemend Nederland, Utrecht.

Hendriks, Kees, Snep, Robbert, de Vries, Barry \& Reinder Brolsma (2016). Groene daken in Tilburg. Operationele handvatten voor ontwikkeling van gemeentelijk beleid. Alterra-rapport 2692. Alterra Wageningen UR, Wageningen. $62 \mathrm{p}$.

Henkens, René, Jansje van Loon-Steensma, Ron Franken, Sandy van Tol en Bart de Knegt (2014). Kustbescherming. In: B. de Knegt (ed.), Graadmeter Diensten van Natuur. Vraag, aanbod, gebruik en trend van goederen en diensten uit ecosystemen in Nederland. WOt-technical report 13. Wageningen: WOT Natuur \& Milieu, Wageningen UR. P. 113- 122. 
Leenders, Caroline van, en Anne-Marie Bor (2014). Bedrijven en Biodiversiteit. Inzichten uit de Community of Practise. Rijksdienst voor Ondernemend Nederland. 73p.

Mill, B.P.A. van, Gooskens, B.J.F., van Schelven, R.M. \& A. Stutje (2013). Externe audit green deal aanpak. Kwink groep. 71p.

Min. EZ (2013). Natuurbeleidsplan Caribisch Nederland. Natuurbeleid voor Caribisch Nederland 2013-2017. 31p. Ministerie van Economische Zaken, Den Haag

Min. EZ (2014). Rijksnatuurvisie 2014. Ministerie van Economische Zaken, Den Haag.

Min. EZ (2014b). Natuurambitie Grote Wateren 2050 en verder. Ministerie van Economische Zaken, Den Haag. 76 p.

Min. EZ (2016). Aanbieden beleidsevaluatie green deals. Ministerie van Economische Zaken, Den Haag. Kamerbrief 29 juni 2016.8 p.

Min. EZ (2016b). Aanpak Weidevogels. Ministerie van Economische Zaken, Den Haag. Kamerbrief 2 november 2016. 12 p.

Min. EZ \& Min. I\&M (2013). Uitvoeringsagenda Natuurlijk Kapitaal: behoud en duurzaam gebruik van biodiversiteit. Ministerie van Economische Zaken en Ministerie van Infrastructuur en Milieu. Kamerbrief, kenmerk DGNR-NB / 13091035. 16p.

Noordijk, Jinze, Katrien Delille, André P. Schaffers \& Karlè V. Sýkora (2009). Optimizing grassland management for flower-visiting insects in roadside verges. Biological Conservation 142: 2097-2103.

Oorschot, Mark van, Johan Brons, Jan Janse, Trudy Rood, Edward Vixseboxse, Harry Wilting en Siemen van Berkum (2015). Duurzame handelsketens onder de loep. Achtergronden bij 'Verduurzaming van internationale handelsketens'. PBL-publicatienummer 1147. Planbureau voor de Leefomgeving, Den Haag. 128p.

Oorschot, Mark van, Trudy Rood, Edward Vixseboxse, Harry Wilting en Stefan van der Esch (2012). De Nederlandse voetafdruk op de wereld: hoe groot en hoe diep? Den Haag: Planbureau voor de Leefomgeving. 61p.

Ottburg, F.G.W.A. en R.J.H.G. Henkens (2015). Kennistabel mitigerende maatregelen. Alterra-rapport 2683. Wageningen, Alterra Wageningen UR. $18 \mathrm{blz.}$

PBL (2016). Balans van de Leefomgeving. Planbureau voor de Leefomgeving, Den Haag.

RVO (2015). Green Deals in beeld. Voortgangsrapportage Green Deals 2011-2015. Rijksdienst voor Ondernemend Nederland. 58 p.

Schuerhoff, Marianne en Arjan Ruijs (2015). Hoe gaan bedrijven om met biodiversiteit? Leren van de Subsidieregeling Biodiversiteit en Bedrijfsleven. Planbureau voor de Leefomgeving, Den Haag. 28p.

Schultz, Martin, Jorren Scherpenisse, Martijn van der Steen en Mark van Twist (2016). Systematisch maatwerk. Green Deals als vorm van strategische netwerksturing. Een essay van de NSOB Denktank. Nederlandse School voor Openbaar Bestuur, Den Haag. 46 p.

SOVON (2012). Vogelbalans 2012. Eds. Kees Koffijberg, Ruud Foppen \& Chris van Turnhout. Sovon Vogelonderzoek Nederland, Nijmegen. 24 p.

Sýkora, Karel V., Jesse M. Kalwij \& Peter-Jan Keizer (2002). Phytosociological and floristic evaluation of a 15-year ecological management of roadside verges in the Netherlands. Preslia, Praha, 74: 421-436.

Vliet, J.M. van \& G. Beers (2011). De gouden driehoek in actie. Praktische voorbeelden van verbinding bedrijf, kennis en overheid. LEI, Den Haag. 116p.

Wallis de Vries, Michiel (2016). Vlindervriendelijk maaien: hoe doe je dat? Vlinders 3/16: 10-13.

Wilting, Harry, Aldert Hanemaaijer, Mark van Oorschot \& Trudy Rood (2015). Trends in Nederlandse voetafdrukken 1995-2010. PBL-publicatienummer: 0707. Planbureau voor de Leefomgeving, Den Haag. $59 \mathrm{p}$.

Wynhoff, I. R. van Gestel, C. van Swaay \& F. van Langevelde (2011). Not only the butterflies: managing ants on road verges to benefit Phengaris (Maculinea) butterflies. J. Insect Conserv. 15: 189-206. 


\section{Verantwoording}

Dit project werd uitgevoerd in opdracht van het Planbureau voor de Leefomgeving. De projectaanpak en resultaten zijn afgestemd met Esther Rotteveel-Kok van het Ministerie van Economische Zaken en Judith Eijs van de Rijksdienst voor Ondernemend Nederland. Interviews met Albert Vliegenthart

(Vlinderstichting), Albert-Jan Olijve (Stichting Veldleeuwerik), Paul van den Heuvel (VVNH) en Marien Borgstein (STIRR) heeft meer inzicht gegeven in concrete resultaten en beleving van de Green Deals Biodiversiteit.

De auteurs bedanken allen voor hun bijdrage aan het tot stand komen van deze rapportage. 


\section{Bijlage 1 Scoringstabellen GDs Biodiversiteit}

\begin{tabular}{|c|c|c|c|c|c|c|c|c|c|c|c|c|c|c|c|c|c|c|c|c|c|c|c|}
\hline \multirow[b]{2}{*}{ Code } & \multirow[b]{2}{*}{ Green Deal Biodiversiteit } & \multirow[b]{2}{*}{$\begin{array}{l}\text { Bijdrage } \\
\text { biodiversiteit }\end{array}$} & \multirow[b]{2}{*}{ 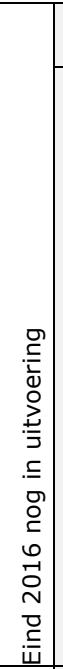 } & \multicolumn{8}{|c|}{ Rijksnatuurvisie } & \multicolumn{4}{|c|}{ Uitvoeringsagenda } & \multicolumn{5}{|c|}{$\begin{array}{c}\text { Indicatoren potentieel } \\
\text { effect op N\&B }\end{array}$} & \multicolumn{3}{|c|}{ Innovatiefase } \\
\hline & & & & 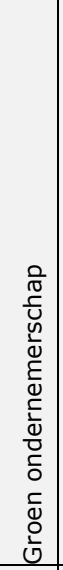 & 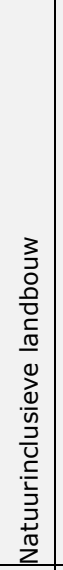 & 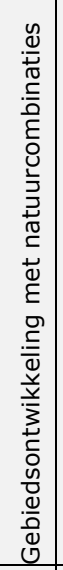 & 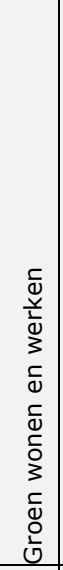 & 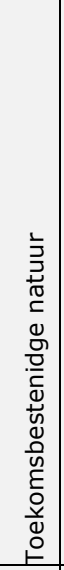 & 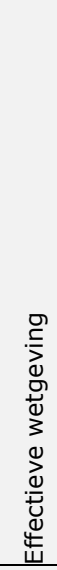 & 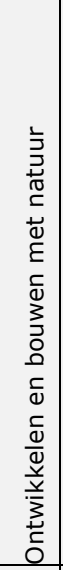 & 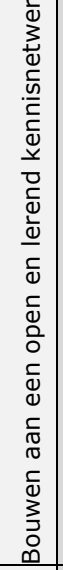 & 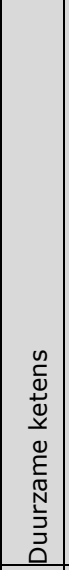 & 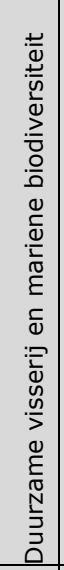 & 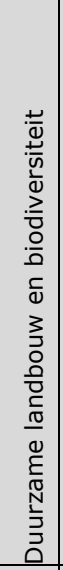 &  & 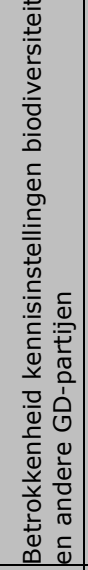 & 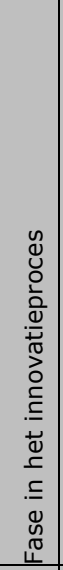 & 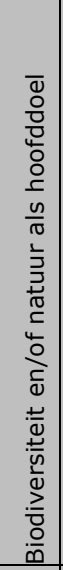 &  & 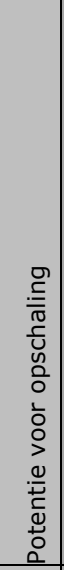 & 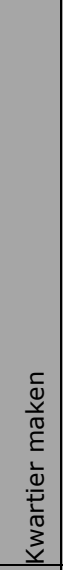 & 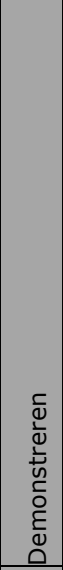 & $\begin{array}{l}\frac{c}{0} \\
\frac{0}{0} \\
\text { پ } \\
0 \\
0\end{array}$ \\
\hline GD001 & Groene Groei & Marginaal (energie) & & $\mathrm{x}$ & & & & & & & & & & & & & $\mathrm{x}$ & & & $\mathrm{x}$ & $\mathrm{X}$ & $\mathrm{x}$ & $\mathrm{x}$ \\
\hline GD009 & De Kruideniersgroep, CoP 'Bedrijven en Biodiversiteit' & Direct & & $\mathrm{X}$ & $\mathrm{x}$ & $\mathrm{X}$ & $\mathrm{X}$ & $\mathrm{X}$ & $\mathrm{X}$ & $\mathrm{X}$ & $\mathrm{X}$ & & & & & & $\mathrm{X}$ & $\mathrm{X}$ & & $\mathrm{X}$ & $\mathrm{X}$ & $\mathrm{x}$ & $\mathrm{x}$ \\
\hline GD037 & Natuurlijk Kapitaal (zie GD 103, 104, 105, 106, 107, 138) & Direct & & $\mathrm{X}$ & & & & $\mathrm{X}$ & $\mathrm{X}$ & $\mathrm{x}$ & & & & & & & $\mathrm{X}$ & $\mathrm{X}$ & & $\mathrm{X}$ & $\mathrm{X}$ & $\mathrm{x}$ & $\mathrm{x}$ \\
\hline GD046 & Gemeente Amsterdam & Marginaal (energie) & & $\mathrm{X}$ & & & & & & & & & & & & & & & $\mathrm{X}$ & & $\mathrm{X}$ & & \\
\hline GD049 & DE-on & \begin{tabular}{|l} 
Marginaal (energie) \\
\end{tabular} & & $\mathrm{X}$ & & & & & & & & $\mathrm{X}$ & & & & & & & & & $\mathrm{X}$ & & \\
\hline GD065 & Biodiversiteit en Economie & Direct & & $\mathrm{x}$ & $\mathrm{x}$ & $\mathrm{x}$ & $\mathrm{x}$ & $\mathrm{x}$ & $\mathrm{x}$ & $\mathrm{x}$ & $x$ & $x$ & $\mathrm{x}$ & $\mathrm{x}$ & $\mathrm{x}$ & $x$ & $\mathrm{x}$ & $\mathrm{x}$ & & $x$ & $x$ & $x$ & $\mathrm{x}$ \\
\hline GD066 & \begin{tabular}{|l|} 
Tijdelijke Natuur \\
\end{tabular} & \begin{tabular}{|l|} 
Direct \\
\end{tabular} & & $\mathrm{x}$ & & & & & $\mathrm{X}$ & $\mathrm{x}$ & $\mathrm{x}$ & & & & & $\mathrm{x}$ & $\mathrm{x}$ & $\mathrm{x}$ & $\mathrm{X}$ & $\mathrm{X}$ & $\mathrm{x}$ & $\mathrm{x}$ & $\mathrm{x}$ \\
\hline GD068 & Veenvervanging & Indirect & & $\mathrm{X}$ & & & & & & & & & & & & $x$ & & $\mathrm{X}$ & & & $\mathrm{x}$ & & \\
\hline GD069 & Vogelwerende Teelt Olifantsgras & \begin{tabular}{|l|} 
Marginaal (energie) \\
\end{tabular} & & & & & & & & & $\mathrm{X}$ & $x$ & & & & & $\mathrm{x}$ & & $\mathrm{X}$ & & $x$ & $\mathrm{x}$ & \\
\hline GD070 & Biomimicry & Indirect & & $\mathrm{X}$ & & & & & & & $\mathrm{x}$ & $\mathrm{x}$ & & & & $\mathrm{x}$ & & $\mathrm{x}$ & & & $\mathrm{X}$ & & \\
\hline GD071 & Biodiversiteit + label & Indirect & & $\mathrm{x}$ & $\mathrm{x}$ & & & & $\mathrm{x}$ & & & & & $\mathrm{x}$ & & $x$ & $\mathrm{x}$ & $\mathrm{x}$ & $\mathrm{X}$ & & $\mathrm{x}$ & $x$ & \\
\hline GD072 & Producerend Landschap & Direct & $\mathrm{x}$ & $\mathrm{X}$ & $\mathrm{x}$ & $\mathrm{x}$ & & $\mathrm{x}$ & & & & & & $\mathrm{x}$ & & $\mathrm{X}$ & $\mathrm{x}$ & $\mathrm{x}$ & & & $\mathrm{x}$ & $\mathrm{x}$ & \\
\hline GD073 & Samen ondernemen in Landbouw en Natuur & Direct & $\mathrm{x}$ & $\mathrm{X}$ & $\mathrm{x}$ & $\mathrm{x}$ & & $\mathrm{x}$ & & & & & & $\mathrm{x}$ & & $\mathrm{x}$ & $\mathrm{X}$ & $\mathrm{X}$ & $\mathrm{X}$ & & $\mathrm{x}$ & $\mathrm{x}$ & \\
\hline GD074 & Biodiversiteit Oosterschelde & Direct & & $\mathrm{X}$ & & $\mathrm{X}$ & & $\mathrm{X}$ & & & & $\mathrm{X}$ & & & & & & & & & $\mathrm{X}$ & & \\
\hline GD075 & Het Landgoedbedrijf & Indirect & & $\mathrm{X}$ & & $\mathrm{x}$ & & $\mathrm{X}$ & $\mathrm{x}$ & & $\mathrm{x}$ & & & & & $\mathrm{x}$ & $\mathrm{x}$ & $\mathrm{x}$ & & $\mathrm{x}$ & $x$ & $\mathrm{x}$ & \\
\hline GD083 & Nationale Federatie Stadsgerichte Landbouw i.o. & Marginaal (voedsel) & & $\mathrm{X}$ & & & $\mathrm{X}$ & & & $\mathrm{x}$ & $\mathrm{x}$ & & & & & & & & & & $\mathrm{x}$ & & \\
\hline GD101 & Biomassavergister Winterswijk & Marginaal (energie) & & $\mathrm{X}$ & & $\mathrm{X}$ & & & & & & $\mathrm{X}$ & & & & & & & & & $\mathrm{x}$ & & \\
\hline GD102 & Blauwzaam Lint & Direct & & $\mathrm{X}$ & & $\mathrm{X}$ & $\mathrm{X}$ & $\mathrm{X}$ & & $\mathrm{X}$ & & & & & & $x$ & $\mathrm{x}$ & $\mathrm{x}$ & $\mathrm{x}$ & $\mathrm{x}$ & $x$ & $x$ & $x$ \\
\hline
\end{tabular}




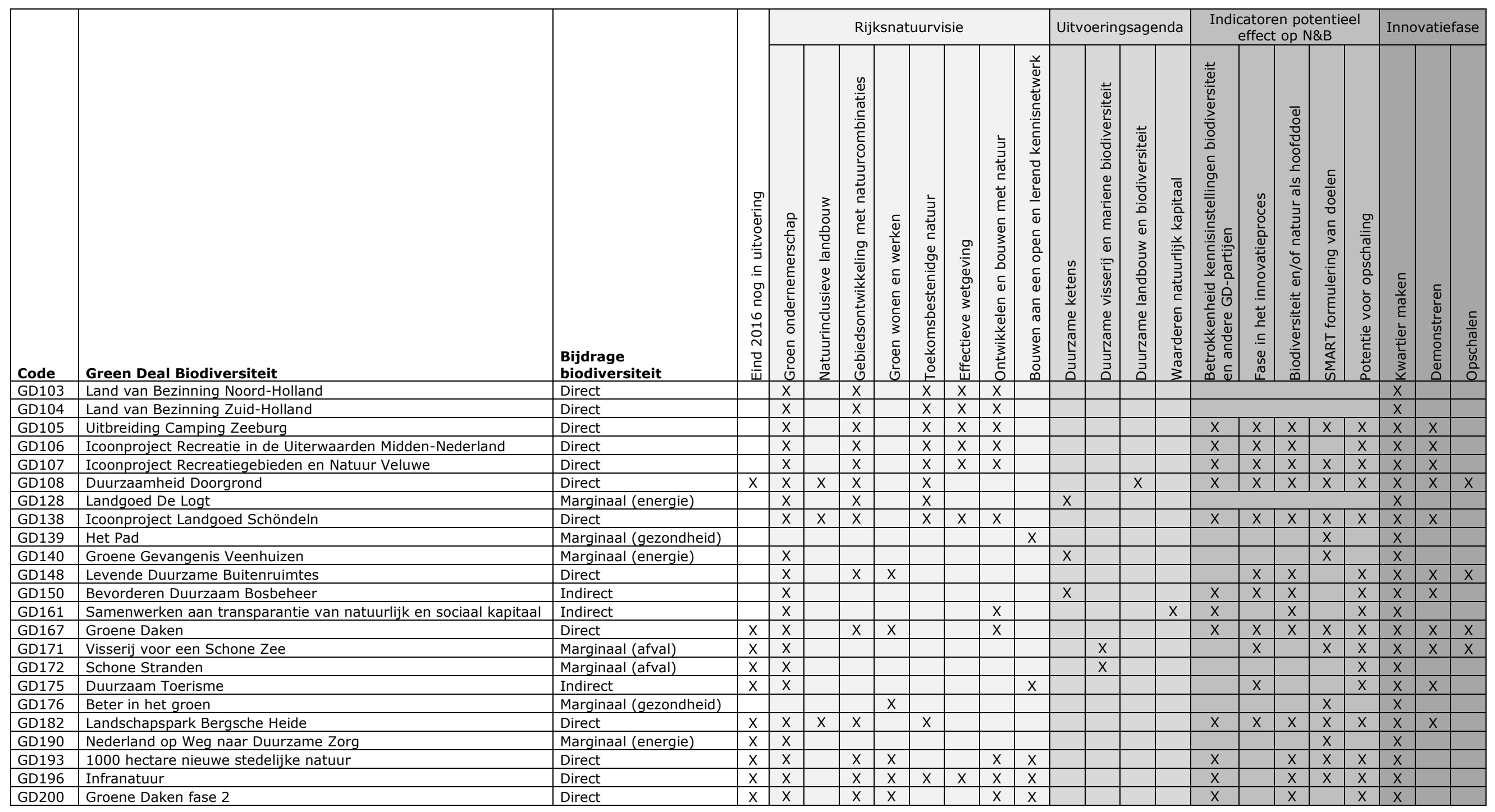

54 | wot-technical report 94 


\section{Bijlage 2 Interviewverslagen}

\section{Vlinderstichting}

Verslag interview Albert Vliegenthart, ecoloog Vlinderstichting.

Bij welke Green Deals Biodiversiteit (GDs) is de Vlinderstichting allemaal betrokken geraakt? De Vlinderstichting is inmiddels betrokken bij acht afgeronde, lopende of toekomstige GDs Biodiversiteit. Vanaf 2011 was de Vlinderstichting al officieel partij bij de GD Tijdelijke Natuur (GD066). Ze was in 2012 zijdelings betrokken bij de GD Blauwzaam Lint (GD102). Vanaf 2013 participeert De Vlinderstichting in "De levende tuin" de bewustwordingscampagne van de GD Levende Duurzame Buitenruimtes (GD148). Ze was vanaf 2014 en 2016 partij in de GDs Groene daken fase 1 en 2 (respectievelijk GD167 en GD200) en vanaf 2015 in de GD 1000 hectare nieuwe stedelijke natuur (GD193) en trekt zelf sinds 2016 de GD Infranatuur (GD196). Daarnaast zal de Vlinderstichting partij zijn in de GD Biomassa die momenteel door Rijkswaterstaat wordt opgezet. Deze toekomstige GD heeft raakvlakken met de GD Infranatuur.

\section{Wat wil de Vlinderstichting met al deze GDs?}

Het is geen financieel gewin. Het gaat De Vlinderstichting vooral om het verwezenlijken van haar ambities ten zien van natuurbescherming en -ontwikkeling, met daarbij natuurlijk vooral oog voor insecten zoals vlinders, libellen en bijen. De kleinschalige vlinderidylles, bijenhotels en dergelijke die concreet worden gerealiseerd zijn leuk, vooral voor de bewustwording, maar het eigenlijke ambitieniveau ligt veel hoger. De Vlinderstichting heeft de ambitie om het Natuurnetwerk Nederland (NNN) te versterken door de natuur daarbuiten te ontwikkelen. Daar liggen immers nog vele onbenutte kansen voor natuurontwikkeling zoals op bedrijventerreinen, (tijdelijk) braakliggende terreinen, daken, terreinen langs infrastructuur enzovoorts. Het GDs concept is een goed middel gebleken om die ambities te kunnen verwezenlijken.

Er is inmiddels bijvoorbeeld 3000 hectare tijdelijke natuur ontwikkeld op terreinen die liggen 'te wachten' op hun uiteindelijke bestemming. Daar is veel biodiversiteitwinst mee geboekt. De uiteindelijk bestemming van braakliggende terreinen kan immers vele jaren, soms 15-20 jaar, duren. In de tussentijd kan er zich biodiversiteit ontwikkelen die zich van daaruit naar de omgeving kan verspreiden. Daarmee fungeren de tijdelijke natuurterreinen als een soort ecologische kraamkamers of stapstenen, waarmee je de natuur in de omgeving versterkt. De uitgangspunten en aanpak van de GD Tijdelijke Natuur sluit ook goed aan op de andere GDs waar De Vlinderstichting bij betrokken is.

De Vlinderstichting doet ook onderzoek naar het vergroten van de biodiversiteit, overigens niet alleen binnen de GDs. Onderzoek naar de ecologische effecten van de verschillende vormen van maaien bijvoorbeeld. Dit is van groot belang om het beheer van wegbermen en andere terreinen binnen de verschillende GDs te verbeteren.

Ook doet de Vlinderstichting onderzoek naar groene daken en hoe deze moeten worden ingericht. Het gaat er dan om dat de verschillende soorten een groen dak als leefgebied gaan gebruiken, zodat ze zich er kunnen voortplanten en in het substraat kunnen overwinteren. Een gangbaar sedumdak is daarvoor veel te beperkt. Er wordt nu onder andere via citizen science (enigszins vergelijkbaar met de tuinvogeltelling) onderzocht welke soorten onder welke omstandigheden op daken worden gesignaleerd (de potentiële biodiversiteitwaarde van een klein dak op 13-hoog verschilt bijvoorbeeld van een groot dak op de $1^{\mathrm{e}}$ verdieping). Met die kennis kunnen richtlijnen worden opgesteld voor het ontwikkelen van biodiversiteit op de verschillende daktypen.

Wat ziet de Vlinderstichting als de belangrijkste resultaten van de GDs? Kwartier maken Het GD concept waarbij men samen met de overheid, marktpartijen, NGO's en andere partijen concrete afspraken kan maken blijkt sterk. Het gaat in eerste instantie niet om geld. Er komt bij de verschillende partijen vooral veel positieve energie en enthousiasme los. 
Doordat de overheid medeondertekenaar is van de GDs, betekent dit dat ze (naast de logistieke ondersteuning) ervoor openstaan om te zoeken waar de ruimte zit om biodiversiteit te bevorderen. Bijvoorbeeld om naast de flexibiliteit bij semi-overheden te onderzoeken om dit thema te verwezenlijken, (bijvoorbeeld infrabeheer), ook te zoeken naar natuurmaatregelen. Het gaat om gesprekken over wet- en regelgeving, voorwaarden en kaders.

De verschillende partijen doen enthousiast mee aan de GDs. Niet in de laatste plaats vanwege de kennisdeling. Zo was er binnen de GD Infranatuur een samenwerking tussen zes waterschappen die dezelfde problematiek op verschillende wijze aanpakten. Na samenwerking binnen de GD ontstond consensus over sommige strategieën.

Ook bínnen de deelnemende organisaties treedt veel bewustwording op. Vergroening van bedrijventerreinen met nieuwe natuur levert bijvoorbeeld veel positieve feedback. Het vergroot het draagvlak voor andere te nemen verduurzamingsmaatregelen binnen de organisatie. De Vlinderstichting wordt nu bijvoorbeeld al gevraagd om mee te denken over de vergroening van de bedrijfsstrategie van Vitens en Prorail.

\section{Oplossen knelpunten}

Verschillende werkgroepen onderzoeken op verschillende thema's hoe knelpunten kunnen worden opgelost. Vooral knelpunten i.r.t. wet- en regelgeving bij bijvoorbeeld aanbestedingen, omgevingsmanagement en businessmodellen. Bijvoorbeeld hoe een bedrijf als Tennet rekening kan houden met biodiversiteit op de afdeling inkoop.

Sommige knelpunten zijn al opgelost. Aan andere wordt nog gewerkt omdat GDs nog in uitvoering zijn. De GD Tijdelijke natuur heeft geleid tot aanpassingen in de flora en faunawetgeving. Met een ontheffing Tijdelijke Natuur op zak kan een bedrijf nu zorgeloos tijdelijke natuur laten ontwikkelen, omdat het die nieuwe natuur later weer (met zorg) mag verwijderen. Een binnen de GD ontwikkelde gedragscode tijdelijke natuur moet waarborgen dat dit ook op zorgvuldige wijze gebeurt. Het grote voordeel van de gedragscode is de uniformiteit, omdat de verantwoordelijkheid hiervoor bij het ministerie ligt. Het voorkomt immers dat een ontheffing, vanwege decentralisatie naar de 12 provincies, ook 12 keer verschillend wordt geïnterpreteerd.

\section{Pilots en opschaling}

Het gaat niet alleen om bewustwording, samenwerken en kwartier maken. Er zijn ook concrete resultaten zichtbaar. Bijvoorbeeld:

- GD Tijdelijke Natuur: In samenwerking met de Haven Amsterdam en de 12 Landschappen is de Stichting Tijdelijke Natuur opgericht. De GD Tijdelijke Natuur was afgerond, maar alle partijen vonden dat het daar niet bij moest blijven. Er zijn inmiddels 40 ontheffingen Tijdelijke Natuur verleend en ruim 3000 hectare gerealiseerd. De Stichting Tijdelijke Natuur fungeert als een vraagbaak en kennisplatform voor partijen die op de resterende circa 30 tot 35.000 ha braakliggend terrein aan de slag willen.

De positieve ervaringen met de GD Tijdelijke Natuur hebben mogelijk een positief effect gehad op de ontwikkeling van een aantal GDs die daarna zijn afgesloten, en waar de Vlinderstichting bij betrokken is geraakt. Dit zou je eveneens als een opschaling kunnen beschouwen.

- GD Infranatuur: de verschillende partijen proberen bewust natuur binnen hun projecten te verwezenlijken. Bij Tennet proberen projectleiders sinds het tekenen van de GD Infranatuur bewust natuur binnen hun projecten te verwezenlijken. De Vlinderstichting gaat bijvoorbeeld het veld in met als doel om het terrein rond electriciteitsstations te vergroenen. Bij Rijkswaterstaat wordt ermee geëxperimenteerd om ecologische vraagstukken reeds in de aanbesteding mee te geven. Bouwbedrijf Heijmans bijvoorbeeld blijkt snelwegverbreding reeds bij projectaanvang binnen een ecologische structuur uit te gaan voeren.

\section{Wat ziet de Vlinderstichting als verdienmodellen?}

Er zijn verschillende verdienmodellen mogelijk. Aan de meeste wordt nog gewerkt door de verschillende partijen. Enkele voorbeelden:

- GD Infranatuur: dijken met een grasmat met diverse kruiden en grassen zijn vanwege de diversere bewortelingsstructuur veel sterker dan dijken met raaigras en schapen. Sterkere dijken zijn veiliger en het dijkonderhoud zou wellicht minder frequent hoeven worden uitgevoerd wat miljoenen zou kunnen besparen op het dijkonderhoud. Onderzoek hiernaar is nog gaande. 
- GD Groene daken: groene daken zijn weliswaar isolerend wat energiebesparing oplevert en ze houden water vast, maar dit zet relatief weinig zoden aan de dijk. Interessanter zijn de mogelijke financiële voordelen wanneer je een dak volgens bepaalde richtlijnen inricht, bijvoorbeeld ten aanzien van de waterschapsbelasting, gemeentelijke heffingen of WOZ-waarde.

- GD Groene daken: Biodiversiteitpakketten worden nu met een leverancier concreet ontwikkeld om een dak in te kunnen richten als leefgebied. Daar is niet veel voor nodig. Weliswaar zijn veel daken niet sterk genoeg als leefgebied, maar op de hoeken bij muren is al veel mogelijk.

\section{Wil de Vlinderstichting niet ook in de Cariben aan de slag?}

Willen is het probleem niet. Er zijn verschillende pogingen geweest om in de Cariben iets voor elkaar te krijgen. Vlindermonitoring met behulp van scholen bijvoorbeeld of werken aan habitatherstel. Men wil daar ook wel, maar de prioriteiten liggen nog teveel bij andere vormen van biodiversiteit zoals zeeschildpadden. Zo is er een nieuwe database opgezet, terwijl er geen aansluiting is met bestaande databronnen. Er is geen geld voor vlinders (niet belangrijk) en vooralsnog ook niet voor GDs. Men hoopt dat partijen als De Vlinderstichting juist geld meenemen. Binnen de overheid zou een prioritering moeten worden opgesteld over terrestrische biodiversiteit. 


\section{Stichting Veldleeuwerik}

Verslag interview Albert Jan Olijve, projectmanager Stichting Veldleeuwerik.

\section{Aanleiding}

Flevolandse akkerbouwers merkten al enige jaren dat hun grond minder begon op te leveren. Er was steeds meer input nodig van onder andere gewasbeschermingsmiddelen en meststoffen om de opbrengst op peil te houden. Dit leidde ook tot zorg bij afnemers van landbouwproducten, zoals Heineken. Deze vroeg zich af hoe Nederland op een duurzamere manier de benodigde grondstoffen kon produceren. Op initiatief van Heineken is in 2002 met 10 Flevolandse akkerbouwers een project gestart, met als doel om een gelijke of zelfs betere opbrengst te behalen met zo min mogelijk input, tegen zo laag mogelijke kosten en met zo weinig mogelijk schadelijke effecten op het milieu.

Na drie jaar werd duidelijk dat er heel veel mogelijk was met een duurzamere bedrijfsvoering. Om dit initiatief op te kunnen schalen werd in 2006 Stichting Veldleeuwerik opgericht. Binnen Stichting Veldleeuwerik werken akkerbouwers aan verduurzaming van de voedselproductie, tezamen met toeleveranciers, adviseurs en afnemers.

\section{Wat houdt de Veldleeuwerik methode in?}

Stichting Veldleeuwerik heeft een eigen duurzaamheidssystematiek ontwikkeld gebaseerd op continu verbeteren. Duurzaamheid is nooit "af", maar een dynamisch proces. De duurzaamheidssystematiek van Veldleeuwerik is gecertificeerd en internationaal erkend. De systematiek bestaat uit drie onderdelen: het duurzaamheidsdossier, de regiogroep en kennisbijeenkomsten.

- Duurzaamheidsdossier: Elke Veldleeuwerik-teler werkt aan het verduurzamen van zijn onderneming. Door het nemen van duurzaamheidsmaatregelen die passen bij zijn bedrijf. Hij maakt dit zichtbaar in zijn duurzaamheidsdossier, wat bestaat uit het duurzaamheidsplan en het duurzaamheidsprofiel. Het duurzaamheidsplan wordt elke jaar door de akkerbouwer, en met behulp van een geaccrediteerde duurzaamheidsadviseur, opgesteld. Deze heeft een accreditie-traject doorlopen bij Aeres Hogeschool Dronten. Leidraad in het duurzaamheidsplan zijn 10 indicatoren (waaronder biodiversiteit). De vooruitgang wordt elk jaar zichtbaar gemaakt met een lijst van 250 mogelijke duurzaamheidsmaatregelen. De akkerbouwer geeft elk jaar aan welke maatregelen hij/zij heeft genomen.

- Regiogroep: elke akkerbouwer zit in een van de huidige 40 zogenaamde regiogroepen van 10-12 akkerbouwers. Deze komen jaarlijks minimaal 8 keer bij elkaar onder begeleiding van een regio coördinator. De helft van deze coördinatoren komt van Praktijk Onderzoek Plant en Omgeving (PPO) van de Wageningen UR. In deze groep worden de duurzaamheidsplannen van elk bedrijf besproken en worden ervaringen gedeeld.

- Kennisbijeenkomsten: elk jaar worden verschillende kennisbijeenkomsten georganiseerd bijvoorbeeld over actuele duurzaamheidsthema's.

De methode Veldleeuwerik is bottom-up. En dat werkt. Ondernemers hebben passie en trots. Ze kiezen zelf de maatregelen. Als ze waren opgelegd hadden ze ze waarschijnlijk niet genomen. Ze dragen het ook uit. Ze bespreken elkaars ervaringen kritisch binnen de groep van 10-12 akkerbouwers. Men wil kennis opdoen om het eigen bedrijf te verbeteren. Het past goed bij de betreffende ondernemers omdat het ook voorlopers zijn. Duurzaamheid is voor hen meer een license to deliver dan een license to produce.

Liefst $90 \%$ van de financiering van Stichting Veldleeuwerik en de aangesloten coördinatoren komt van de aangesloten bedrijven zoals Heineken en BASF (kennis op vlak bijen, gewasbescherming) en de boeren de rest in de vorm van projectsubsidie van de overheid.

\section{Wat was de meerwaarde van de GD?}

De GD was erg belangrijk voor de kwaliteit en opschaling van de Veldleeuwerik systematiek. Het aantal aangesloten akkerbouwers bleef groeien en er was zorg of de kwaliteit wel voldoende gewaarborgd kon worden. Daarop is besloten om een certificering te ontwikkelen die past bij de manier van werken van Veldleeuwerik. De GD heeft vervolgens ook deuren geopend bij het ministerie in Den Haag en de Europese Commissie in Brussel. Na geslaagde onderhandelingen krijgen akkerbouwers met een Veldleeuwerikcertificaat meer keuzemogelijkheid bij de verplichting om $5 \%$ van hun areaal in te vullen als ecologisch aandachtsgebied. De waardering uit Brussel werd erg gewaardeerd door de boeren. Het eerst jaar hebben 22 ondernemers geopteerd om via Veldleeuwerik het GLB in te vullen. 
Voor de start van de GD waren er iets meer dan 100 akkerbouwers aangesloten, vooral in Flevoland. Momenteel zijn dat er 390 door het hele land, evenals een 60-tal bedrijven/partners daaromheen (zoals Heineken).

\section{Hoe gaat het verder met de opschaling?}

Het aantal aangesloten akkerbouwers en partners blijft groeien maar het moet vooral gestaag en stabiel blijven. Kwaliteit staat voorop. Het gaat er ook niet om om alle akkerbouwers aangesloten te krijgen. De systematiek moet wel bij een ondernemer passen. Vaak zie je een cluster van participerende akkerbouwers. Mond-op-mond reclame blijkt erg belangrijk. De bottom-up Veldleeuwerik-aanpak zou ook in het buitenland kunnen worden toegepast, maar daar ligt de focus niet.

Afgelopen jaren zijn heel druk geweest met de certificering. Nu de GD is afgelopen is er weer ruimte om meer naar buiten te treden. De missie voor komende jaren is om het kennisplatform op een hoger niveau te tillen. Volgend jaar 15-jarig bestaan, met groot congres.

\section{Welke maatregelen worden er genomen voor de biodiversiteit?}

Nieuwe aangesloten Veldleeuwerik-akkerbouwers leggen de eerste 3 jaar heel erg de focus op de indicator bodemvruchtbaarheid. Ervaring leert namelijk dat een biodiverse bodem stabieler is en daardoor minder gevoelig is voor perioden van droogte of neerslag. Het kan net het verschil maken tussen een goede oogst en een misoogst. Biodiversiteit zit als indicator waarop wordt ingezet een beetje in de middenmoot. Uiteindelijk zal elke ondernemer binnen 4 jaar maatregelen hebben genomen op alle 10 indicatoren, dus ook op biodiversiteit. Het gaat dan om maatregelen zoals akkerrandenbeheer, nestkasten, het wintergroen houden van de akker e.d.

Omdat veel ondernemers al bij een agrarisch collectief zitten wordt vaak al veel gedaan aan meerjarig/ eenjarig akkerrandenbeheer. Het enthousiasme voor akkerranden is na het nieuwe GLB echter minder geworden, omdat er minder vergoeding tegenover staat vanuit het ministerie. De collectieven in Flevoland richten zich vooral ook op niet kerende grondbewerking en het wintergroen houden van akkers wat voedsel oplevert voor vogels en andere biodiversiteit. Ook het plaatsen van nestkasten is een maatregel die vaak wordt genomen.

\section{Wat is nou het concrete effect op de biodiversiteit?}

Dat is eigenlijk nog niet goed onderzocht dus valt dit niet concreet aan te geven. In 2017 start er echter een twee jaar durend monitoringproject in de Hoekse Waard. De deelnemende bedrijven daar nemen maatregelen op het gebied van akkerranden, bodemvruchtbaarheid, energie en gewasbeschermingsmaatregelen. Het gaat dan om het meten van de effecten op plaagbestrijders, bestuivers e.d. Dit zal in samenwerking zijn met Hoeksewaardse Landschapsvrijwilligers, Stichting EIS en de Universiteit van Amsterdam.

\section{Welke kennisinstellingen biodiversiteit zijn betrokken?}

Verschillende kennisinstellingen zijn reeds (zijdelings) betrokken bij de Veldleeuwerik systematiek, zoals Het Louis Bolk Instituut, PPO Lelystad en andere organisaties binnen WUR, de Vogelbescherming, SOVON e.d. Toch is er de wens om het kennisplatform veel breder te ontwikkelen, waarbij de focus ligt op drie thema's: Bodem, Gewasbescherming en Biodiversiteit.

De kennisagenda wordt samengesteld met partners waaronder ook WUR, Louis Bolk, Expertisecentrum bodembiodiversiteit e.d. Er bestaat veel interesse voor de bovengrondse biodiversiteit, maar vooral ook voor de bodembiodiversiteit, omdat dit een positief effect heeft op de stabiliteit van de productie en de kwaliteit van het product.

Zo wil men meer weten over het effect van bepaalde gewasbeschermingsmiddelen op het bodemleven, omdat men ziet dat er een negatief effect is. De gewasontwikkeling op een deel van het perceel waar net een ander middel is gebruikt, is soms anders dan op de rest van het perceel. Is dit invloed van een middel op het bodemleven? Het gaat daarbij niet zozeer om wormen, maar vooral om schimmels, bacteriën e.d. Bepaalde gewasbeschermingsmiddelen past men bijvoorbeeld al niet meer toe, ook al waren ze standaard. Op 15 juni 2017 is er een door Stichting Veldleeuwerik georganiseerd groot congres met workshops op de verschillende actuele thema's met, naar verwachting, circa 1000 bezoekers. 


\section{Vereniging Van Nederlandse Houtondernemingen (VVNH)}

Verslag interview Paul van den Heuvel, directeur VVNH

De Koninklijke Vereniging Van Nederlandse Houtondernemingen (VVNH) is de overkoepelende brancheorganisatie van 205 groothandelsbedrijven in hout. De VVNH is als ondernemersorganisatie lid van het Nederlands Verbond van de Groothandel (NVG) en daarmee verbonden aan het VNO/NCW. Circa 90\% van het hout dat in Nederland geconsumeerd wordt komt uit het buitenland. De impact is mondiaal want het hout wordt uit 48 verschillende landen geïmporteerd, variërend van de tropen tot de poolcirkel. De GD Bevorderen Duurzaam bosbeheer liep in de periode 2013-2015.

\section{Wat was het hoofddoel van de GD?}

Het lange termijn doel is dat gecertificeerd (duurzaam) geproduceerd hout de norm ofwel mainstream wordt in Nederland. Die stip op de horizon is gezet in 2020. Het voornaamste doel van de GD was feitelijk om kwartier te maken, als voorbereiding voor een opschaling na 2015, het jaar waarin de GD afloopt.

\section{Waren de doelen SMART geformuleerd?}

De meeste ondertekenaars hebben de activiteiten waaraan ze zich hebben gecommitteerd uitgevoerd. Het betrof in de meeste gevallen echter een inspanningsverplichting op het gebied van communicatie en kennisoverdracht. Concrete targets voor het gebruik van duurzaam geproduceerd hout waren niet geformuleerd en het gebruik van duurzaam geproduceerd hout door de leden van de GD is ook niet gemonitord. Die is wel gemonitord in de houthandel, maar dat gebeurt al langer en buiten de GD. SMART formulering van doelen bleek lastig. FSC/PEFC konden niet aan de GD deelnemen omdat de NMA afspraken tussen concurrenten verbiedt. Een duidelijke belemmering.

\section{Wat is bereikt met de GD?}

\section{Kwartiermaken}

De GD was de eerste stap om (vrijwel) alle partijen die van invloed zijn op de consumptie van hout en houtproducten in Nederland om de tafel te krijgen. Al waren er ook achterblijvers. Bedrijven in de houthandel die niet aangesloten zijn bij de VVNH en daardoor lastig zijn te bereiken.

Het proces om tot de GD te komen heeft 1,5 jaar geduurd en uiteindelijk waren er 27 organisaties officieel partner. Er is bewust met veel marktpartijen gewerkt om de krachten te bundelen en knelpunten te analyseren. Deelnemende partijen waren onder andere de overheid (Ministeries van Infrastructuur en Milieu en Economische Zaken), het bedrijfsleven (vertegenwoordigd door vele branche organisaties, zoals retail, meubelindustrie, etc.), vakbonden, woningcorporaties en de NGO's IUCN en Tropenbos International.

\section{Bewustwording in de hele houtketen}

De bewustwording over nut en noodzaak van certificering in de hele houtketen is door de GD gegroeid, mede doordat alle participerende organisaties een promotende rol op zich hebben genomen.

Zonder GD was het lastiger om de boodschap over te brengen dat de markt met duurzaam en op zijn minst legaal hout aan de slag moet. De combinatie van veel partijen gaf makkelijker toegang tot bijvoorbeeld gemeenten en waterschappen. Daar bestond veel verwarring over FSC, PEFC en FLEGT. Dankzij de GD is nu bij een aantal partijen duidelijk gemaakt dat PEFC ook voldoet. De bewustwording over inkoopregels is daarmee duidelijk vergroot.

Ook is de bewustwording vergroot dat je bossen juist kan behouden door ze duurzaam te gebruiken en verantwoord te kappen. Liever secundair bos dan helemaal geen bos. NGOs zoals Tropenbos International spelen hierin een belangrijke communicatieve rol. "Use it or loose it" wordt meer en meer het credo in plaats van eerdere negatieve slogans zoals "kappen met kappen" of "fout hout", die door kritische NGOs zijn gebruikt. Een dergelijke boodschap zorgt ervoor dat consumenten negatief gaan denken over het product hout, wat vervolgens een belemmering kan worden voor het stimuleren van het kopen van duurzaam geproduceerd hout.

\section{Knelpuntenanalyse}

De onderzoeken die zijn uitgevoerd in het kader van de GD hebben veel nieuwe informatie en kennis omtrent knelpunten en mogelijke oplossingsrichtingen opgeleverd. Belangrijk knelpunt is onder andere de meerkosten van gecertificeerd hout ten opzichte van niet-gecertificeerd hout. Duurzaam hout kan nooit 
mainstream worden als het prijsverschil zo groot blijft, met name bij tropisch hout. Mogelijke oplossingen liggen in een herziening van het belastingstelsel, bijvoorbeeld een verlaagd BTW-tarief en/of minder heffing van invoerrechten voor duurzame producten. Het Ministerie van Financiën en de EU gaan hier echter (nog) niet in mee, want het kan leiden tot ongeoorloofde uitsluiting van aanbieders van hout. De financiële knelpunten zijn met de GD weliswaar nog niet opgelost, maar de discussie hierover is wel opgestart in de keten. Aan andere knelpunten is met deze GD juist invulling gegeven aan oplossingen, zoals beperkte bewustwording bij gebruikers van hout, en beperkte kennis over inkoopregels bij (decentrale) overheden.

\section{Nederland heeft voortrekkersrol}

Nederland kan het niet alleen. Willen we echt komen tot een duurzaam behoud van bossen wereldwijd, dan zullen ook andere landen stappen moeten zetten om voor het gehele bedrijfsleven een gelijk speelveld te creëren. De GD met alle betrokken partijen is uniek binnen de EU en daarbuiten en kan een inspirerende werking hebben op andere landen. Dat wordt nu vormgegeven in de EU STTC (European Sustainable Tropical Timber Coalition). Het is belangrijk om die boodschap te communiceren. NGO's zoals Tropenbos International spelen hierin een belangrijke rol, vooral voor wat betreft de tropische bossen.

Hoe staat het met de opschaling van de GD?

De GD gaf veel positieve energie en het was dan ook belangrijk om het momentum niet te verliezen. In eerste instantie wilde de VVNH een GD 2.0 opzetten, maar omdat het Ministerie van Buitenlandse Zaken ook aanhaakte wordt het waarschijnlijk een (IMVO) convenant (Internationaal Maatschappelijk Verantwoord Ondernemen).

De reden om een IMVO-convenant op te zetten is het gevolg van de door het Ministerie van Buitenlandse Zaken (BuZa) gevraagde risicoanalyse van 113 branches (uitgevoerd door KPMG), waaruit bleek dat er bij 10-15 een risico is. De tropische houthandel is er daar één van. De intentie/belofte van BuZa is om voor een aantal sectoren convenanten af te sluiten. Het convenant richt zich sterk op OESO guidelines voor multinationals, een vorm van beleid waar Nederland toezeggingen op heeft gedaan bij de OECD. Onderzoek i.o.v. het Ministerie van Buitenlandse Zaken dat is uitgevoerd door FORM International toont aan dat met FSC en PEFC gecertificeerd bos en hout aan de OESO richtlijnen en het SER advies wordt voldaan.

\section{Deelnemende partijen}

Het convenant wordt wederom afgesloten met een groot aantal partijen, waaronder ook weer de NGO's Tropenbos International en IUCN. Andere NGO's, zoals WWF, Greenpeace en Milieudefensie, zijn echter niet aangehaakt in het convenant. Dat heeft te maken met de positie van de Timber Procurement Assessment Committee (TPAC) die aan de hand van een standaard beoordeeld of iets wel of niet duurzaam is. FSC is door de commissie helemaal goedgekeurd, net als PEFC. Het Maleisisch PEFC moet echter nog een aantal verbeterpunten doorvoeren en had daardoor volgens een aantal NGO's nog niet goedgekeurd mogen worden. Het beoordelingsproces inzake PEFC-MTCS is anno nu nog gaande. Voor de actuele situatie wordt verwezen naar de TPAC website http://www.tpac.smk.nl/32/home.html.

\section{SMART-doelen}

Het convenant kent in tegenstelling tot de GD wél afrekenbare kwantitatieve en gedifferentieerde doelen voor legaal/ duurzaam hout. Om zeker te zijn dat het convenant de goede doelen bevat is een rapport verschenen over compliance van FSC/PEFC met de OESO richtlijn, aangezien de sector sterk gericht is op FSC/PEFC en FLEGT/EUTR.

Het convenant is vrijwillig maar niet vrijblijvend. Er wordt een monitoring opgezet wat de basis is om partijen weer aan te kunnen spreken.

Nederlandse voortrekkersrol blijft.

Net als met de GD is het Nederlandse convenant rond de duurzame handel in hout uniek. De doelen en beleid voor duurzaam hout in andere landen zien er heel anders uit.

\section{Wat is het effect geweest van de GD op de biodiversiteit?}

Momenteel is circa 18-19\% van het bos wereldwijd FSC/PEFC gecertificeerd. Of de GD heeft bijgedragen aan een toename van dit percentage kan niet worden aangegeven. Dat is niet gemeten. De aanbodkant van het hout en het gevoerde bosbeheer is eigenlijk sowieso niet in beeld geweest. De titel Bevorderen duurzaam bosbeheer is dan ook eigenlijk misleidend. Het ging meer om de vraagkant. "Bevorderen van de afzet van 
duurzaam hout op de Nederlands markt" zou een passender titel van de GD zijn geweest. Daar zijn mooie resultaten geboekt, inmiddels is $82 \%$ van het aangeboden hout gecertificeerd. Maar daar heeft de GD niet echt aan bijgedragen, dat proces is in de houthandel al jaren gaande.

Natuurlijk speelt de vraag wel of het bevorderen van duurzaam hout effect heeft op de mondiale ontbossing. Het aandeel tropisch import naar NL loopt al jaren terug (vooral onder invloed van de economische crisis), dus de impact kan nooit heel groot zijn. Daarom is samen optrekken in de EU heel belangrijk. Dat is al tot stand gekomen door initiatieven die in samenwerking met IDH zijn opgezet.

Internationaal speelt nu vooral het EU beleid over legaliteit (EUTR \& FLEGT). In de Voluntary Partnership Agreements (VPAs) die onder FLEGT zijn gesloten wordt gestuurd op handhaving van de boswetgeving in herkomstlanden. Indonesië is het eerste land dat FLEGT compliance hout mag verhandelen (onder de noemer V-legal \& TLAS). 


\section{Stichting Innovatie Recreatie en Ruimte (STIRR)}

Verslag interview Marien Borgstein, projectregisseur kennisprogramma's STIRR.

De GD Natuur \& Gastvrijheid is een koepeldeal, waarbij door de ondertekenaars (Min. EZ, Min IenM, STIRR en RECRON) is afgesproken dat er minimaal vijf pilots of icoonprojecten dienden te worden geselecteerd. Hierin experimenteren gastvrijheidsondernemers met verdienmodellen voor investeringen in natuur, of zoals is in de GD-teksten is verwoord 'combineren van groen en groei waarbij het groen meer moet zijn dan compensatie alleen'. Voor elk icoonproject is vervolgens een GD afgesloten.

Als onderdeel van het Innovatieprogramma Groei \& Groen heeft het Ministerie van EZ aan de STIRR de opdracht verleend om de projecten gedurende de looptijd ( 3 jaar) te monitoren. De resultaten zijn vervolgens gepubliceerd in de brochure Aan tafel! Samenwerken aan groen, groei en gastvrijheid Lessen uit Green Deals Natuur \& Gastvrij. Deze brochure is in maart 2016 aangeboden aan Minister Kamp.

\section{Op welke knelpunten hebben de GDs Natuur \& Gastvrijheid zich gericht?}

De vraag vanuit recreatie en toerisme is aan verandering onderhevig. Om het aanbod daarop af te stemmen, moeten gastvrijheidsondernemers blijven innoveren. Vaak bestaat er echter een angst bij overheden, natuurorganisaties en omwonenden dat een uitbreiding of vernieuwing van een gastvrijheidsbedrijf tot natuurschade of tot extra overlast zal leiden: groen zou ten koste gaan van groen. Enerzijds heeft dit te maken met het soms negatieve imago van de sector, maar vaak ook is er in plannen onvoldoende rekening gehouden met belangen van anderen. Een ondernemer start met een voor hem geweldig (uitgekristalliseerd) plan, waarbij hij verwacht dat de gemeente daarin meegaat. De gemeente kan zich dan overvallen voelen waardoor er reacties kunnen ontstaan in de zin van 'zien van beren op weg' en 'bang voor precedentwerking'. Uiteindelijk leert de ervaring dat ondernemers dan vaak een ontwikkeltraject van jaren ingaan.

\section{Welke oplossingen zijn er binnen de GDs Natuur \& Gastvrijheid toegepast?}

Het gaat er vooral om dat de gastvrijheidsondernemer met zijn/haar plan verder kijkt dan zijn eigen ambities. Men moet (potentiële) andersdenkenden in de 'meewerk modus' krijgen. Heel belangrijk is dat er een gedeelde sense of urgency bestaat, ook wel de urgentiedriehoek genoemd. De gedachte is dat een gastvrijheidsondernemer zijn wens om te vernieuwen (ondernemersurgentie) verbindt met wensen die leven in de gemeenschap (gebiedsurgenties) en bij de overheid (beleidsurgentie). Hierdoor ontstaat een plan waar niet alleen de ondernemer warm voor loopt, maar ook diverse andere partijen. Wat volgt is een gezamenlijke inzet om dit plan tot een succes te maken. De kans op realisatie wordt dan aanzienlijk vergroot en procedures worden veelal sneller doorlopen. Zo krijgen recreanten een mooiere omgeving met fraaiere bedrijven; krijgen ondernemers een license to operate en meer medewerking om te bouwen aan een nieuw toekomstperspectief met meer financiële armslag en een mooiere setting en kunnen overheden en terreinbeheerders meer groene doelen realiseren tegen lagere publieke kosten en is er ook een breed maatschappelijk draagvlak voor de realisatie van de plannen en eventuele bestemmingsplan wijziging. Kortom, groen en groei kan samengaan.

Een en ander is gemakkelijker gezegd dan gedaan. Het is dan ook heel belangrijk dat dit proces wordt begeleid door een onafhankelijke facilitator die goed kan voorzitten, luisteren, verslag kan leggen en intervenieren waar mogelijk door zelf te acteren of een externe partij erbij te betrekken. STIRRmedewerkers hebben deze rol bij de betreffende GDs vervuld. In de GDs ging men om de drie maanden om de tafel, waarbij telkens kleine en soms grote stappen werden gezet. Dat de rijksoverheid als partij aanschoof werkte bovendien stimulerend omdat het voor de andere partijen een signaal was dat het initiatief blijkbaar interessant was voor het Rijk en 'dus iets voorstelde'.

\section{Is er sprake van opschaling?}

Er zijn geen nieuwe GDs Natuur \& Gastvrijheid meer gepland. Het proces dat in de GDs is gevolgd kan ook zonder officiële GD worden toegepast. De GD hoeft ook niet perse vanuit het Rijk of de Provincie worden ingestoken. Men kan ook op gemeenteniveau een GD-achtige constructie opzetten. De Provincie en het Rijk kunnen aanschuiven wanneer zij als partij een toegevoegde waarde zien. Het gaat er vooral om dat er een goede facilitator aanwezig is die het communicatieproces en de urgentiedriehoek kan faciliteren, en tegelijkertijd ook inhoudelijk interventies kan plegen dan wel kan organiseren via derden. De aanpak en de ervaringen zijn verwoord in de brochure Aan tafel! Samenwerken aan groen, groei en gastvrijheid Lessen uit 
Green Deals Natuur \& Gastvrij. Deze brochure is breed uitgezet via de RECRON de STIRR en anderen. Er zijn inmiddels verschillende nieuwe GD-achtige projecten onderweg. Er is goede hoop dat de GD-aanpak algemeen goed wordt om de vele knelpunten binnen de sector aan te pakken en STIRR kan hier ook in de toekomst een ondersteunende rol in spelen.

\section{Waar had de sector gestaan zonder de GD?}

De GD en de participerende koplopers hebben de sector nieuw elan gegeven. Het blijkt dat vanuit de sector recreatie geïnnoveerd kan worden en dat dit tegelijkertijd ten goede kan komen aan groene doelen. Groene groei dus. Het heeft ook allemaal relatief weinig overheidsgeld gekost, dus de drempel om deze aanpak te kopiëren is niet hoog. De GD heeft feitelijk voor de boost gezorgd die de sector nodig had.

\section{Heeft groene groei ook echt tot meer biodiversiteit geleid?}

De effecten op de biodiversiteit zijn nog niet gemonitord omdat dat ook niet de opdracht was binnen de GD. De opdracht was om innovaties te realiseren op het vlak van groen en groei waarbij het te ontwikkelen groen meer moest zijn dan compensatie alleen. In GD-termen wordt dan gesproken over 'compensatie+'. Alle ondernemers hebben binnen de GD's een beheer- en inrichtingsplan moeten maken die door een ecologisch deskundige is goedgekeurd. Dat kan bijvoorbeeld een ecoloog zijn van de gemeente of een lokale natuurorganisatie. De suggestie om ook andere partijen te betrekken, zoals de Vlinderstichting of RAVON, wordt als een interessante optie gezien. Door het maken van deze plannen hebben de ondernemers inzichtelijk gemaakt wat die 'compenstatie+' dan is voor het groen. Het effect op de biodiversiteit zal dus ook pas na enige jaren geduid kunnen worden. Hiervoor zou een aanvullend onderzoek gestart kunnen worden.

\section{Wat is nou eigenlijk het verdienmodel bij de GDs Natuur \& Gastvrijheid?}

Het feit dat wordt geïnvesteerd in mooie omgeving betaald zich terug. De ondernemer krijgt een groener imago, heeft een goed verhaal en onderscheid zich daarmee van zijn concurrenten. Veelal kan men daardoor ook een hogere prijs vragen voor het recreatieve product. 


\section{Verschenen documenten in de reeks Technical reports van de Wettelijke Onderzoekstaken Natuur}

\& Milieu vanaf 2015

WOt-technical reports zijn verkrijgbaar bij het secretariaat van Unit Wettelijke Onderzoekstaken Natuur \& Milieu te Wageningen. T 0317 - 4854 71; E info.wnm@wur.nl

WOt-technical reports zijn ook te downloaden via de website www.wur.nl/wotnatuurenmilieu

35 Kuindersma, W., F.G. Boonstra, R.A. Arnouts, R. Folkert, R.J. Fontein, A. van Hinsberg \& D.A. Kamphorst (2015). Vernieuwingen in het provinciaal natuurbeleid; Vooronderzoek voor de evaluatie van het Natuurpact.

36 Berg van den, F., W.H.J. Beltman, P.I. Adriaanse, A. de Jong \& J.A. te Roller (2015). SWASH Manual 5.3. User's Guide version 5

37 Brouwer, F.M., A.B. Smit \& R.W. Verburg (2015). Economische prikkels voor vergroening in de landbouw

38 Verburg, R.W., R. Michels, L.F. Puister (2015). Aanpassing Instrumentarium Kosten Natuurbeleid (IKN) aan de typologie van het Subsidiestelsel Natuur en Landschap (SNL)

39 Commissie Deskundigen Meststoffenwet (2015). Actualisering methodiek en protocol om de fosfaattoestand van de bodem vast te stellen

40 Gies, T.J.A., J. van Os, R.A. Smidt, H.S.D. Naeff \& E.C. Vos (2015). Geografisch Informatiesysteem Agrarische Bedrijven (GIAB); Gebruikershandleiding 2010.

41 Kramer, H., J. Clement (2015). Basiskaart Natuur 2013. Een landsdekkend basisbestand voor de terrestrische natuur in Nederland

42 Kamphorst, D.A., T.A. Selnes, W. Nieuwenhuizen (2015). Vermaatschappelijking van natuurbeleid. Een verkennend onderzoek bij drie provincies

43 Commissie Deskundige Meststoffenwet (2015). Advies 'Mestverwerkingspercentages 2016'

44 Meeuwsen, H.A.M. \& R. Jochem (2015). Openheid van het landschap; Berekeningen met het model ViewScape

45 Groenestein, C.M., J. de Wit, C. van Bruggen \& O. Oenema (2015). Stikstof- en fosfaatexcretie van gangbaar en biologisch gehouden landbouwhuisdieren. Herziening excretieforfaits Meststoffenwet 2015

46 Bruggen, C. van, A. Bannink, C.M. Groenestein, J.F.M. Huijsmans, H.H. Luesink, S.M. van der Sluis, G.L. Velthof \& J. Vonk (2015). Emissies naar lucht uit de landbouw, 1990-2013. Berekeningen van ammoniak, stikstofoxide, lachgas, methaan en fijn stof met het model NEMA.

47 Boonstra, F.G. \& A.L. Gerritsen (2016) Systeemverantwoordelijkheid in het natuurbeleid; Input voor agendavorming van de Balans van de Leefomgeving 2014

48 Overbeek, M.M.M., M-J. Bogaardt \& J.C. Dagevos (2015). Intermediairs die bijdragen van burgers en bedrijven aan natuur en landschap mobiliseren.

49 Os, J. van, R.A.M. Schrijver \& M.E.A. Broekmeyer (2015). Kan het Natuurbeleid tegen een stootje? Enkele botsproeven van de herijkte Ecologische Hoofdstructuur.
50 Hennekens, S.M., J.M. Hendriks, W.A. Ozinga, J.H.J. Schaminée \& L. Santini (2015). BioScore 2 Plants \& Mammals. Background and pre-processing of distribution data

51 Koffijberg K., P. de Boer, F. Hustings, A. van Kleunen, K. Oosterbeek \& J.S.M. Cremer (2015). Broedsucces van kustbroedvogels in de Waddenzee in 2011-2013.

52 Arets, E.J.M.M., J.W.H van der Kolk, G.M. Hengeveld J.P. Lesschen, H. Kramer, P.J. Kuikman \& M.J. Schelhaas (2015). Greenhouse gas reporting of the LULUCF sector in the Netherlands. Methodological background.

53 Vonk, J., A. Bannink, C. van Bruggen, C.M. Groenestein, J.F.M. Huijsmans, J.W.H. van der Kolk, H.H. Luesink, S.V. Oude Voshaar, S.M. van der Sluis \& G.L. Velthof (2016). Methodology for estimating emissions from agriculture in the Netherlands. Calculations of $\mathrm{CH}_{4}, \mathrm{NH}_{3}, \mathrm{~N}_{2} \mathrm{O}, \mathrm{NO}_{4}$ $P M_{10}, P M_{2.5}$ and $\mathrm{CO}_{2}$ with the National Emission Model for Agriculture (NEMA)

54 Groenestein, K. \& J. Mosquera (2015). Evaluatie van methaanemissieberekeningen en -metingen in de veehouderij.

55 Schmidt, A.M. \& A.S. Adams (2015). Documentatie Habitatrichtlijn-rapportage artikel 17, 2007-2012

56 Schippers, P., A.M. Schmidt, A.L. van Kleunen \& L. van den Bremer (2015). Standard Data Form Natura 2000; bepaling van de belangrijkste drukfactoren in Natura 2000-gebieden.

57 Fey F.E., N.M.A.J. Dankers, A. Meijboom, C. Sonneveld, J.P. Verdaat, A.G. Bakker, E.M. Dijkman \& J.S.M. Cremer (2015). Ontwikkeling van enkele mosselbanken in de Nederlandse Waddenzee, situatie 2014

58 Blaeij, A.T. de, R. Michels, R.W. Verburg \& W.H.G.J. Hennen (2015). Recreatiemodule in Instrumentarium Kosten Natuurbeleid (IKN); Bepaling van de recreatiekosten

59 Bakker, E. de, H. Dagevos, R.J. Fontein \& H.J. Agricola (2015). De potentie van co-creatie voor natuurbeleid. Een conceptuele en empirische verkenning.

60 Bouwma, I.M., A.L. Gerritsen, D.A. Kamphorst \& F.H. Kistenkas (2015). Policy instruments and modes of governance in environmental policies of the European Union; Past, present and future

61 Berg, F. van den, A. Tiktak, J.J.T.I. Boesten \& A.M.A. van der Linden (2016). PEARL model for pesticide behaviour and emissions in soil-plant systems; Description of processes

62 Kuiters, A.T., G.A. de Groot, D.R. Lammertsma, H.A.H. Jansman \& J. Bovenschen (2016). Genetische monitoring van de Nederlandse otterpopulatie; Ontwikkeling van populatieomvang en genetische status 2014/2015 
63 Smits, M.J.W., C.M. van der Heide, H. Dagevos, T. Selnes \& C.M. Goossen (2016). Natuurinclusief ondernemen: van koplopers naar mainstreaming?

64 Pouwels, P. , M. van Eupen, M.H.C. van Adrichem, B. de Knegt \& J.G.M. van der Greft (2016). MetaNatuurplanner v2.0. Status $A$

65 Broekmeyer, M.E.A. \& M.E. Sanders (2016) Natuurwetgeving en het omgevingsrecht. Achtergrond-document bij Balans van de Leefomgeving, 2014

66 Os, J. van, J. H.S.D. Naeff \& L.J.J. Jeurissen (2016).Geografisch informatiesysteem voor de emissieregistratie van landbouwbedrijven; GIABplus-bestand 2013 - Status A

67 Ingram, V.J., L.O. Judge, M. Luskova, S. van Berkum \& J. van den Berg (2016). Upscaling sustainability initiatives in international commodity chains; Examples from cocoa, coffee and soy value chains in the Netherlands.

68 Duin van W.E., H. Jongerius, A. Nicolai, J.J. Jongsma, A. Hendriks \& C. Sonneveld (2016). Friese en Groninger kwelderwerken: Monitoring en beheer 1960-2014.

69 Ehlert, P.A.I., T.A. van Dijk \& O. Oenema (2016). Opname van struviet als categorie in het Uitvoeringsbes/uit Meststoffenwet. Advies.

70 Ehlert, P.A.I., H.J. van Wijnen, J. Struijs, T.A. van Dijk, L. van Schöll, L.R.M. de Poorter (2016). Risicobeoordeling van contaminanten in afval- en reststoffen bestemd voor gebruik als covergistingsmateriaal

71 Commissie Deskundigen Meststoffenwet (2016). Protocol beoordeling stoffen Meststoffenwet. Versie 3.2

72 Kramer, H., J. Clement (2016). Basiskaart Natuur 2009. Een landsdekkend basisbestand voor de terrestrische natuur in Nederland

73 Dam, R.I. van, T.J.M. Mattijssen, J. Vader, A.E. Buijs \& J.L.M. Donders (2016). De betekenis van groene zelf-governance. Analyse van verschillende vormen van dynamiek in de praktijk.

74 Hennekens, S.M., M. Boss \& A.M. Schmidt (2016). Landelijke Vegetatie Databank; Technische documentatie, Status A

75 Knegt, B. de, et al. (2016). Kansenkaarten voor duurzaam benutten van Natuurlijk Kapitaal

76 Commissie Deskundigen Meststoffenwet (2016). Advies 'Mestverwerkingspercentages 2017'

77 W.H.J. Beltman, C. Vink \& A. Poot (2016). Calculation of exposure concentrations for NL standard scenarios by the TOXSWA model; Use of FOCUS_TOXSWA 4.4.3 software for plant protection products and their metabolites in Dutch risk assessment for aquatic ecosystems

78 Koffijberg K., J.S.M. Cremer, P. de Boer, J. Postma \& K. Oosterbeek \& J.S.M. Cremer (2016) Broedsucces van kustbroedvogels in de Waddenzee in 2014.

79 Sanders, M.E. G.W.W Wamelink, R.M.A. Wegman \& J Clement (2016). Voortgang realisatie nationaal natuurbeleid; Technische achtergronden van een aantal indicatoren uit de digitale Balans van de Leefomgeving 2016.
80 Vries, S. de \& I.G. Staritsky (2016). AVANAR 2.0 nader beschreven en toegelicht; Achtergronddocumentatie voor Status $A$

81 Kuiters, A.T., G.A. de Groot, D.R. Lammertsma H.A.H. Jansman \& J. Bovenschen (2016). Genetische monitoring van de Nederlandse otterpopulatie; Ontwikkeling van populatieomvang en genetische status 2015/ 2016.

82 Pleijte, M., R. Beunen \& R. During (2016). Rijksprojecten: hét natuurinclusieve werken? Een analyse van relaties tussen rijksprojecten en de Rijksnatuurvisie

83 Smits, M.J.W. en E.J. Bos (2016). Het stimuleren van ondernemen met natuur: handelingsopties voor de overheid

84 Horst, M.M.S. ter, W.H.J. Beltman \& F. van den Berg (2016). The TOXSWA model version 3.3 for pesticide behaviour in small surface waters; Description of processes

85 Mattijssen, T.J.M. (2016). Ideaaltypen en analysekader van groene burgerinitiatieven; Bijlage bij het rapport 'De betekenis van groene burgerinitiatieven: analyse van kenmerken en effecten van 264 initiatieven in Nederland

86 Wösten, J.H.M., F. de Vries \& J.G. Wesseling (2016). BOFEK2012 versie 2; Status $A$

87 Pleijte, M., R. During \& R. Michels (2016). Nationale parken in transitie; governance-implicaties van een veranderend beleidskader

88 Mol-Dijkstra, J.P.\& G.J Reinds (2017). Technical documentation of the soil model VSD+; Status A

89 Arets, E.J.M.M., J.W.H van der Kolk, G.M. Hengeveld, J.P. Lesschen, H. Kramer, P.J. Kuikman \& M.J. Schelhaas (2017). Greenhouse gas reporting for the LULUCF sector in the Netherlands. Methodological background, update 2016

90 Bruggen, C. van, A. Bannink, C.M. Groenestein, J.F.M. Huijsmans, H.H. Luesink, S.V. Oude Voshaar, S.M. van der Sluis, G.L. Velthof \& J. Vonk (2017). Emissies naar lucht uit de landbouw in 2014. Berekeningen met het model NEMA

91 Os van, J., M.G.T.M. Bartholomeus, L.J.J. Jeurissen \& C.G. van Reenen (2017). Rekenregels rundvee voor de landbouwtelling. Verantwoording van het gebruik van $I \& R$ gegevens voor de landbouwtelling

92 Haas, W. de, R.J. Fontein \& M. Pleijte (2017) Ruimtelijke ordening 2.0 - filosofie en praktijk; twee essays over het sturen van natuur- en landschapsopgaven met ruimtelijk beleid

93 Schuiling, C., A. M. Schmidt, I.J. La Rivière \& R.A Smidt (2017). Beschermde gebiedenregister; Technische documentatie, Status $A$.

94 Henkens, R.J.H.G., M.M.P. van Oorschot en J. Ganzevles (2017). Bijdrage van Green Deals aan de beleidsdoelen voor natuur en biodiversiteit 





Thema Balans van de Leefomgeving Wettelijke Onderzoekstaken Natuur \& Milieu

Postbus 47

6700 AA Wageningen

T (0317) 485471

E info.wnm@wur.nl

ISSN 2352-2739

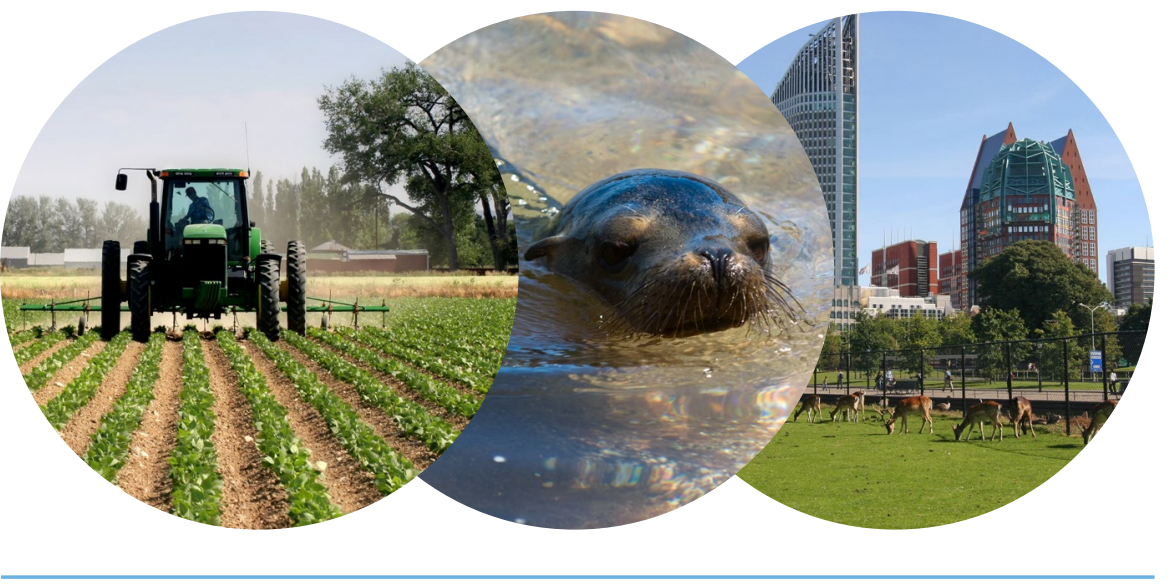

De missie van Wageningen University \& Research is 'To explore the potential of nature to improve the quality of life'. Binnen Wageningen University \& Research bundelen 9 gespecialiseerde onderzoeksinstituten van Stichting Wageningen Research en Wageningen University hun krachten om bij te dragen aan de oplossing van belangrijke vragen in het domein van gezonde voeding en leefomgeving. Met ongeveer 30 vestigingen, 5.000 medewerkers en 10.000 studenten behoort Wageningen University \& Research wereldwijd tot de aansprekende kennisinstellingen binnen haar domein. De integrale benadering van de vraagstukken en de samenwerking tussen verschillende disciplines vormen het hart van de unieke Wageningen aanpak. 